\title{
ASPECTOS BIOLÓGICOS E AVALIAÇÃO DE DANOS DE Spodoptera frugiperda (J. E. SMITH, 1797) (LEPIDOPTERA, NOCTUIDAE) EM ALGODOEIRO
}

\author{
VALQUIRIA DA ROCHA SANTOS VELOSO \\ Engenhoira Agrónoma
}

Orientador: Dr. OCTÁVIO NAKANO

\begin{abstract}
Dissertação apresentada à Escola Superior de Agricultura "Luiz de Queiroz", da Universidade de São Paulo, para obtenção do título de Mestre em Ciências Biologicas Área de Concentração: Entomologia.
\end{abstract}

PIRACICABA

Estado de São Paulo - Brasil

Novembro, 1982 
Aos meus

pais e irmãos

OFEREÇO

Ao meu esposo

RONALDO, pelo estímulo

e compreensão e $\bar{a}$ mi nha filha ALICE

DEDICO 
iii.

\section{AGRADECIMENTOS}

Agradecemos à todas as pessoas que direta ou indiretamente colaboraram na execução deste trabalho, espe cialmente:

Ao Prof. Dr. Octāvio Nakano, pela orientação e apoio no prẹ paro e execução deste trabalho;

Ao Prof. Dr. José Roberto Postali Parra, pelas sugestões e considerações oferecidas;

Ao Prof. Dr. Evôneo Berti Filho, pela colaboração prestada na elaboração do "Summary";

Aos demais Professores do Departamento de Entomologia da ESALQ USP, pelos ensinamentos e atenção dispensada;

A Escola Superior de Agricultura "Luiz de Queiróz", da Uni versidade de São Paulo, Piracicaba, SP, pela oportunida de de aperfeiçoamento;

A Escola de Agronomia da Universidade Federal de Goiās e de modo especial ao Departamento Fitossanitārio, pela oportú 
nidade e facilidades oferecidas para realização do curso de Pōs-Graduação;

Ao Plano Institucional de Capacitação de Docentes (PICD-CAPES), pela bolsa de estudos concedida;

Aos Engenheiros Agrōnomos Lāzaro Josē Chaves e Franciscolva do de 0liveira Melo, pela amizade e orientação na anāli se estatistica dos dados;

Ao Engenheiro Agrônomo Ronaldo Veloso Naves, pela ajuda na condução do trabalho, sugestões e efetiva colaboração:

A Dra. Maria Judy de Melo Ferreira, pelas sugestões e amiza de demonstrada;

As Engenheiras Agrōnomas Maria Clarice Vasconcelos Dias Fer raz e Quelzia Maria Silva Melo, pela amizade e reconheci da ajuda;

Aos Colegas do Curso de Pós-Graduação, pelo incentivo;

A Bibliotecāria Srta. Maria Elizabeth Ferreira de Carvalho, pela revisão da literatura citada;

Aos funcionārios da Biblioteca da ESALQ-USP, em especial ao Sr. Luiz Carlos Veríssimo, pela colaboração prestada. 


\section{INDICE}

Pāgina

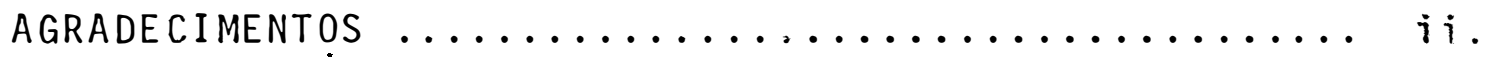

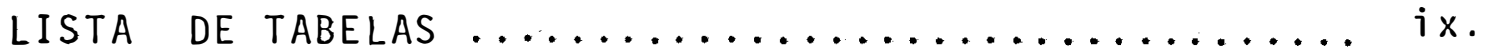

LISTA DE FIGURAS $\ldots \ldots \ldots \ldots \ldots \ldots \ldots \ldots \ldots \ldots \ldots \ldots \ldots \ldots \ldots \ldots \ldots$

LISTA DE APENDICE ..................... xvi

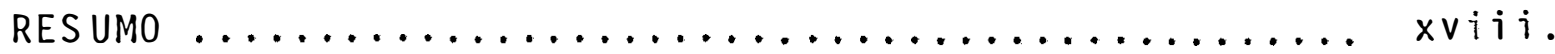

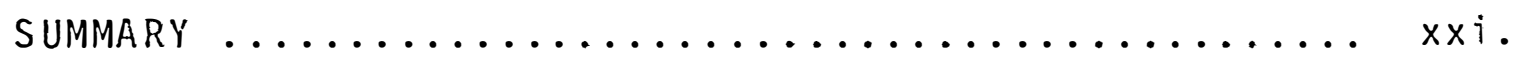

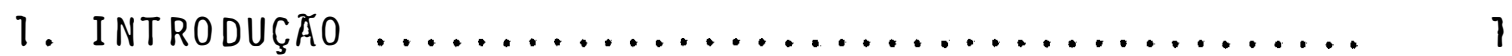

2. REVISÃO dE LITERATURA ................... 3

2.1. Distribuição geogrāfica, plantas hospedeiras

e època de ocorrēncia ................. 3

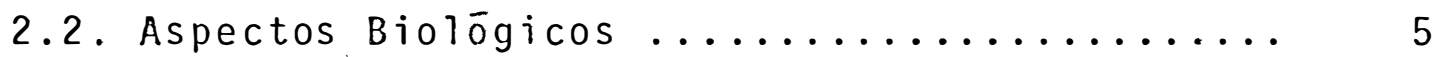

2.2.1. Período de pré-oviposição, capacidade de postura e perĩodo de incubação .... 5

2.2.2. Estāgios de desenvolvimento do inseto. 10

2.2.3. Longevidade dos adultos e nūmero de ge

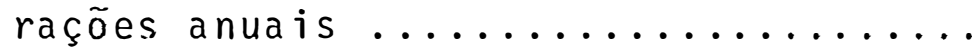


2.3. Danos de spodoptera spp. em algodoeiro..... 18

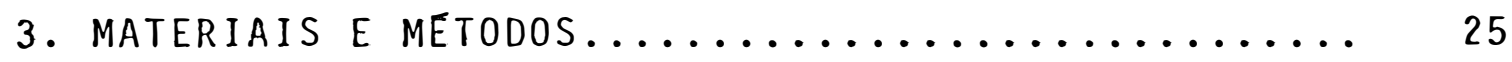

3.1. Experimentos de laboratōrio ........... 25

3.1.1. Biologia comparada de S. frugiperda em folhas de algodoeiro e milho ....... 25

3.1.1.1. Aspectos biológicos estuda dos $\ldots \ldots \ldots \ldots \ldots \ldots \ldots$

3.1.1.2. Técnica de criação de $S$. fru giperda $\ldots \ldots \ldots \ldots \ldots \ldots \ldots$

3.2. Experimentos de campo .............. 30

3.2.1. Determinação dos efeitos de diferen tes nĩveis de infestação da lagarta de $S$. frugiperda na produção do algo doeiro $\ldots \ldots \ldots \ldots \ldots \ldots \ldots \ldots$

3.2.1.1. Local, época, cultivar e tratos culturais ......... 30

3.2.1.2. Condução do experimento, de lineamento experimental etra tamentos $\ldots \ldots \ldots \ldots \ldots \ldots$.

3.2.2. Estruturas frutiferas do algodoeiro da nificadas por lagartas de $S$. frugiper da em diferentes épocas de desenvolvi

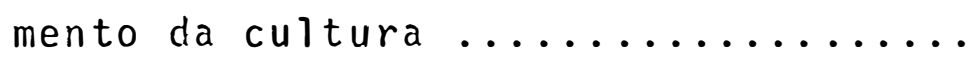

4. RESULTADOS E DISCUSSAO $\ldots \ldots \ldots \ldots \ldots \ldots \ldots$ 
vii.

Pāgina

4.1. Biologia comparada de $S$. frugiperda em folhas de algodoeiro e milho, em condições de labora

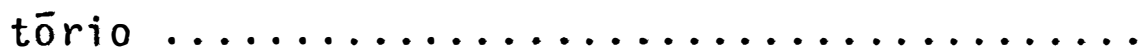

4.1.1. Fase de lagarta ................ 37

4.1.1.1. Duração, viabilidade e peso.. 37

4.1.1.2. Número e duração dos ínstares

larvais $\ldots \ldots \ldots \ldots \ldots \ldots$

4.1.2. Fase de prē-pupa ............... 42

4.1.3. Fase de pupa .................... 44

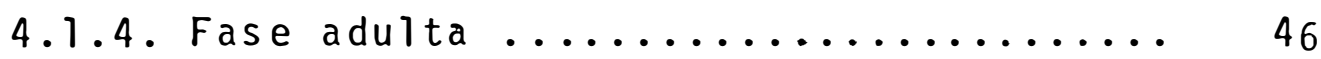

4.1.4.1. Longevidade dos adultos e pe rĩodo de prē-oviposição .... 46

4.1.4.2. Capacidade de postura ..... 46

4.1 .5 . Fase de ovo .................. 49

4.1.6. Ciclo total e considerações gerais ... 50

4.2. Danos de $S$. frugiperda em algodoeiro ....... 56

4.2.1. Determinação dos efeitos dos diferen tes níveis de infestação da lagarta de S. frugiperda na producão do algodoeiro.

4.2.2. Estruturas frutíferas do algodoeiro da nificadas por lagartas de S. frugiperda em diferentes épocas de desenvolvimen to da cultura .................... 72

4.2.2.1. Estado fenológico das plantas de a lgodoeiro ............ 72 4.2.2.2. Nümero de estruturas frutífe 
viii.

Pāgina

$$
\begin{aligned}
& \text { ras danificadas por planta } \\
& \text { com lagartas de } S \text {. frugiperda. } 72
\end{aligned}
$$

5. CONCLUSOES ............................. 81

6. LITERATURA CITADA ........................... 83

7. APENDICE $\ldots \ldots \ldots \ldots \ldots \ldots \ldots \ldots \ldots \ldots \ldots \ldots \ldots \ldots \ldots \ldots \ldots$ 
$i x$.

\section{LISTA DE TABELAS}

TABELAS

Pāgina

1 Composição da dieta para S. frugiperda

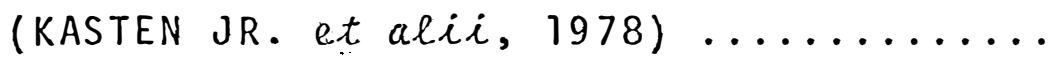

2 Anālise do solo no local do experimento, Piracicaba - SP, $1980 \ldots \ldots \ldots \ldots \ldots$

3 Duração mēdia, viabilidade e peso no māxi mo desenvolvimento de lagartas de $S$. fru giperda criadas em folhas de algodoeiroda cultivar IAC-17 e folhas de milho hibrido HMD-7974, à $25 \pm 2^{0} \mathrm{C}$, UR: $60 \pm 10 \%$ e foto

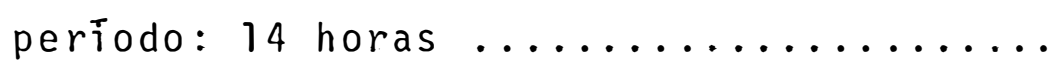

4 Largura mēdia da cāpsula cefálica, razão de crescimento e duração média, por ins tar, de 10 lagartas de $S$. frugiperda cria das em folhas de algodoeiro da cultivar 
TABELA

IAC-17, à $25 \pm 2^{0} \mathrm{C}, \mathrm{U} \cdot \mathrm{R} .: 60 \pm 10 \%$, fotop $\underline{\mathrm{e}}$

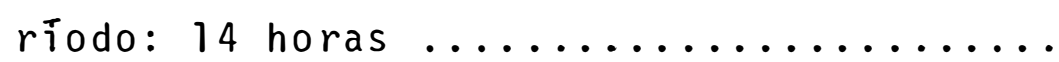

5 Largura média da cápsula cefālica, razão de crescimento e duração mēdia, por ins tar, de 10 lagartas de $S$. frugiperda cria da em folhas de milho híbrido HMD-7974, à $25 \pm 2^{0} \mathrm{C}$, U.R.: $60 \pm 10 \%$ e fotoperiodo: 14

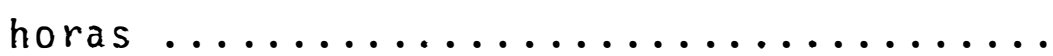

6 Duração e viabilidade da fase de prē-pupa de $S$. frugiperda criadas em folhas de al godoeiro da cultivar IAC-17 e folhas de milho híbrido HMD-7974, à $25 \pm 2^{0} \mathrm{C}$, U.R.: $60 \pm 10 \%$ e fotoperíodo: 14 horas .......

7 Duração, viabilidade, peso e razão sexual das pupas de $S$. frugiperda criadas em fo lhas de algodoeiro cultivar IAC-17 e fo Thas de milho híbrido HMD-7974, à $25 \pm 2^{\circ} \mathrm{C}$; U.R.: $60+10 \%$ e fotoperiodo: 14 horas...

8 Longevidade dos adultos, períodos de pré oviposição, nümero total de ovos, nūmero de posturas por fémea e nümero de ovos por 
postura de $S$. frugiperda, criadas em fo Thas de algodoeiro da cultivar IAC-17 e folhas de milho híbrido HMD-7974, à $25 \pm$ $2^{0}$ C; U.R.: $60 \pm 10 \%$ e fotoperíodo: 14 ho

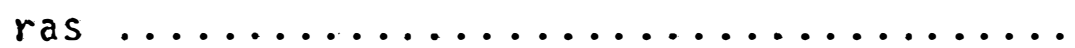

9 Duração média das fases de lagarta, pré pupa, adulto e períodos de incubação de ovos de $S$. frugiperda, obtida de folhas de algodoeiro da cultivar IAC-17 e folhas de milho híbrido HMD-7974, à $25 \pm 2^{0}$ C,U.R.: $60^{\circ} \pm 10 \%$ e fotoperíodo: 14 horas .......

10 Valores médios de produção de algodão em caroço, nūmero de ponteiros cortados e nū mero de pupas encontradas, nas diferentes parcelas das plantas infestadas aos 75 e aos 95 dias da germinação, com lagartas de S. frugiperda, Piracicaba, SP. $1981 \ldots .$.

11 Quadrádos médios (pelo esquema fatorial $4 \times 2$ ) da produção de algodão em caroço e do nūmero de pupas encontradas, envolven do nūmero de insetos e época de infesta 
12 Quadrados médios para os dados de produ ção de algodão em caroço, nümero de pon teiros cortados e nūmero de pupas encon tradas, nas diferentes parcelas das plan tas infestadas aos 75 e 95 dias da germi nação com lagartas de $S$. frugiperda.....

13 Valores mëdios de estruturas frutificação por planta de aigodoeiro em relação às

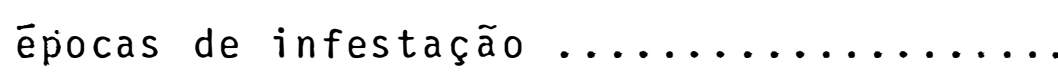

14 Quadrados médios para os nūmeros de bo tões florais, maçãs e totais de estrutu ras danificadas por planta de algodoeiro, pelas lagartas de $S$. frugiperda em dife rentes épocas de desenvolvimento da cultu ra (dados transformados em arc sen $\sqrt{\%}$ ). 76

15 Porcentagens de estruturas frutíferas dani ficadas por planta de algodoeiro pelas lagartas de $S$. frugiperda em diferentes épocas de desenvolvimento da cultura em 
xiii.

TABELA

Pāgina

relação ao total de estruturas frutíferas presente na época da infestação ........

16 Valores médios do nūmero de estruturas fru tîferas danificadas por planta de algodo eiro, pelas lagartas de $S$. frugiperda em diferentes épocas de desenvolvimento da

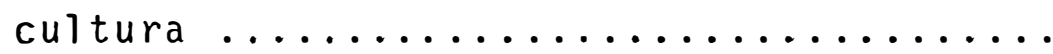


$x i v$

\section{LISTA DE FIGURAS}

FIGURA

Pàgina

1 Gaiolas utilizadas nas infestacões artifi ciais com lagartas de $S$. frugiperda, em con

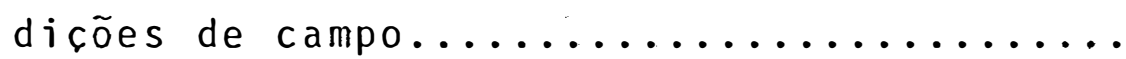

2 Duração média das fases de ovo, lagarga, pré-pupa, pupa e adulto de $S$. frugiperda, cria das em algodoeiro da cultivar IAC-17 e miTho hỉbrido HMD-7974, à $25 \pm 20 \mathrm{C}$; UR. $60 \pm$

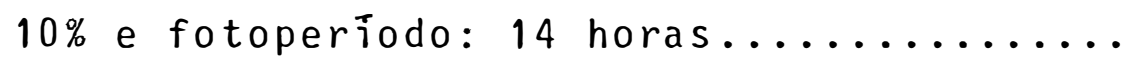

3 Viabilidade das fases de ovo, lagarta, pré- pupa e pupa de $S$. frugiperda, criadas em algodoeiro da cultivar IAC-17 e milho hibri do HMD-7974, à $25 \pm 20 \mathrm{C} ; \mathrm{UR}: 60 \pm 10 \%$ e fo-

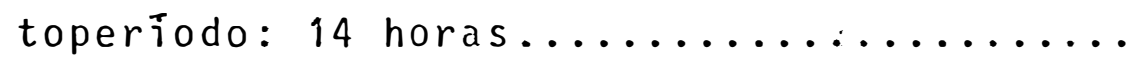


FIGURA

4 Peso das lagartas no máximo desenvolvimento e peso médio de pupas de $S$. frugiperda, cri adas em algodoeiro da cultivar IAC-l7 e mi Tho hỉbrido HMD-7974, à $25 \pm 2^{0} \mathrm{C} ;$ U.R.: 60

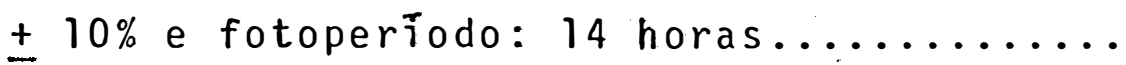

5 Posturas e viabilidades diārias de $S$. frugi perda, criadas em algodoeiro da cultivar IAC 17 e milho híbrido HMD-7974, à $25 \pm 2{ }^{0} \mathrm{C}$, U.R. $60 \pm 10 \%$ e fotopericdo: 14 horas..........

6 Danos de $S$. frugiperda em maçãs de algo-

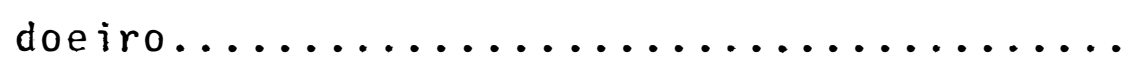

7 Relação entre o nūmero de lagartas e a produção das plantas de algodoeiro infestadas

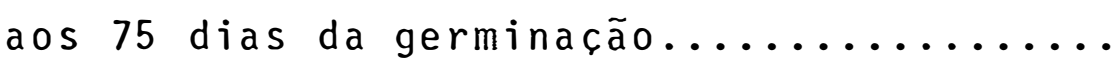

8 Danos de $S$. frugiperda em caulde de algo-

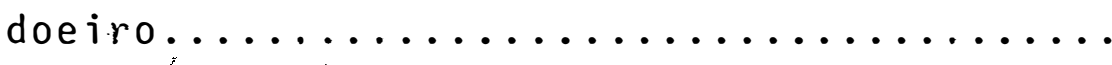

9 Relação entre ó nūmero de lagartas e a produção das plantas de algodoeiro infestadas

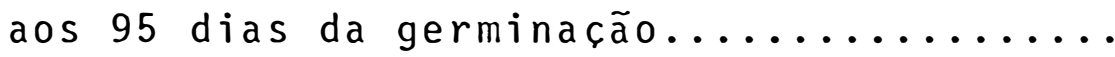


FIGURA

10 Relacão entre o nūmero de lagartas e o nūme ro de ponteiros cortados em plantas de algo doeiro infestadas aos 75 dias da germina-

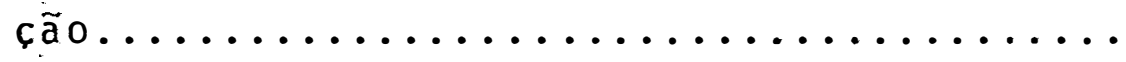

11 Relação entre o nūmero de lagartas e o nūme ro de pupas encontradas na infestação aos 75 dias da germinação das plantas de algodo

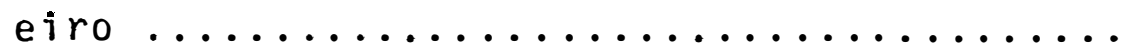

12 Relação entre o nūmero de lagartas e o nūme ro de pupas encontradas na infestação aos 95 dias da germinação das plantas de algodo

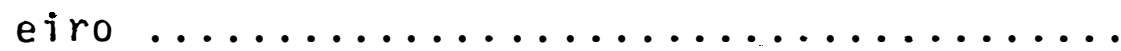

13 Porcentagens de estruturas frutiferas por planta de algodoeiro em relação às épocas de

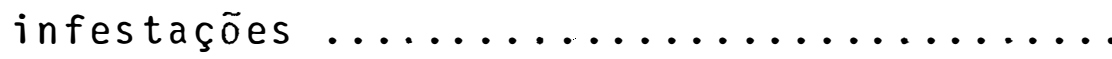

14 Porcentagens, de estruturas frutíferas danifi cadas por lagartas de $S$. Grugiperda em rela ção ao total de estruturas frutîferas pre sente nas plantas, nas épocas de infestação.. 


\section{LISTA DE APENDICE}

APENDICE

Pāgina

1 Precipitação pluviomētrica e temperatura do ar, mensais, referentes ao ano de 1980, registradas no Posto Agrometeorōlogico,do Departamento de Física e Meteorologia da ESALQ/USP, em Piracicaba-SP ..........

2 Precipitação pluviomētrica e temperatura do ar, mensais, referentes ao ano de 1981, registradas no Posto Agrometeorólogico, do Departamento de Física e Meteorolo gia da ESALQ-USP, em Piracicaba-SP ..... 
xviii.

\section{ASPECTOS BIOLÖGICOS E AVALIAÇĀO DE DANOS DE Spodoptera frugiperda (J.E. Smith, 1797) (LEPIDOPTERA, NOCTUIDAE) EM ALGODOEIRO}

Autor: Valquîria da Rocha Santos Veloso

Orientador: Dr. Octāvio Nakano

RESUMO

Estudou-se a biologia comparada de spodoptera frugiperda (J.E. Smith, 1797) em dois substratos naturais e ava liaram-se os danos causados na produção do algodoeiro, verifican do-se tambēm o nūmero de estruturas frutīferas danificadas duran te o período de atividade das lagartas em diferentes épocas de desenvolvimento da cultura. Os aspectos biológicos foram es tudados em laboratório em sala de criação mantida à temperatura de $25 \pm 2^{\circ} \mathrm{C}$, com umidade relativa de $60 \pm 10 \%$ e fotoperiodo de 14 horas. Os substratos naturais utilizados foram folhas de algodo eiro da cultivar IAC-17 e folhas de milho híbrido HMD-7974. $0 \underline{e}$ feito do inseto na produção do algodoeiro e no nūmero de estrú turas frutiferas danificadas foi estudado em condições de cam po com a cultivar IAC-17. Em função dos dados biológicos obti 
dos, observou-se que o perīodo larval e o número de înstares encontrados foram influenciados pelo alimento fornecido, obten do-se uma duração para o período larval de 22,67 e 16,02 dias, respectivamente, em algodoeiro e milho. 0 número de instares larvais foi 7 em algodoeiro e 6 em milho. Os machos de $S$. fru giperda são mais sensīveis ã alteração de alimento, observan do-se um alongamento na duração pupal quando as lagartas se de senvolvem em folhas de algodoeiro. A capacidade de postura foi afetada pelo substrato alimentar, sendo maior para as fêmeas provenientes de lagartas criadas em folhas de milho. 0 ciclo total (de ovo até a morte do adulto) foi de 43,36 e 38,14 di as, respectivamente, em algodoeiro e milho, mostrando, assim, um melhor desenvolvimento em millho. Para a avaliação dos danos causados pelas lagartas na producão do algodoeiro, utilizaram- se 4 nîveis de infestação artificial aos 75 e 95 dias da germinação das plantas. Os danos foram avaliados através da producão de algodão em caroço, por parcela. As diferenças na produção em plantas infestadas aos 75 e 95 dias da germinação, comparadas com a testemunha, foram estatísticamente significativas para as in festações com 1, 2 e 4 lagartas por planta. Aos 75 dias, devido ao fato de existirem poucos órgãos frutíferos, a redução na produção deu-se devido ao ataque das lagartas aos ponteiros e aos caules, com corte parcial ou total. Na infestação aos 95 dias a produção diminuiu linearmente em relação aos diferentes nĩveis de infestação; nesta ēpoca as lagartas mostraram prefe rēncia pelas estruturas frutíferas do algodoeiro. Analisou-se 
$x x$.

tambēm o nümero de estruturass frutíferas danificadas pelas lagartas em diferentes épocas de desenvolvimento da cultura. As épocas de infestação não causaram diferenças significati vas. No entanto, o nümero de insetos afetou significativamente os danos provocados nas maçãs, e o dano total de estruturas fru tiferas. Foi observado, ainda, que a lagarta de $S$. frugiperda destruiu, 3,78 estruturas frutiferas durante o seu desenvolvi mento. 


\title{
BIOLOGICAL ASPECTS AND DAMAGE EVALUATION OF Spodoptera frugiperda (J.E. Smith, 1797) (LEPIDOPTERA, NOCTUIDAE) ON COTTON PLANTS
}

\author{
Author: Valquĩria da Rocha Santos \\ Veloso
}

Adviser: Dr. Octāvio Nakano

SUMMARY

This research deals with the study of the compared biology of Spodoptera frugiperda (J.E. Smith, 1797) on two natural diets. The damage in the cotton yield and the number of fruit structures damaged during the larvae activity in different times of the crop development were also evaluated. The experiment was carried out in laboratory conditions (temperature: $25 \pm 2^{\circ} \mathrm{C}$; Relative Humidity: $60 \pm 10 \% ; 14$-hour photoperiod). The insect was reared on cotton leaves of the cultivar IAC-17 and leaves of the hybrid corn HMD-7974. The effect of the insect in the cotton yield and in the number of damaged fruit structures was studied on the cultivar IAC-17 in field conditions. The data indicated that the larval period and the number of instars of $S$. Grugiperda were influenced by the diet. The larval period lasted 22.67 days on cotton and 16.02 days on corn. The number of instares was 7 on cotton and 6 on corn. The males of $S$. frugiperda 
$x \times i i$

were more sensitive to food change for the pupal period was delayed when the larvae were reared on cotton leaves. The oviposition was higher in the females reared on cotton leaves. The life cycle (from egg to the adult death) was 43.36 and 38.14 days for insects reared on cotton and corn leaves, respectively. To evaluate the decrease in the cotton yield four levels of artificial infestation were used at 75 and 95 days from plant germination. The damage was evaluated on cotton seeds per plot. The differences in the yield of infested plants at 75 and 95 days from germination, when compared to the check, were statistically significant for the infestations of 1,2 and 4 larvae per plant. At 75 days when the plants presented a low number of fruit organs, the yield decrease was due to the attack of larvae cutting partially of totally the shoots and stems. As to the infestation at 95 days the yield decreased lineally in relation to the different levels of infestation; at this time the larvae showed a preference for the fruit structures of the cotton plants. The number of fruit structures damaged by the larvae on different periods of the crop development was also observed. The periods of infestation did not present significant differences. However the number of insects did affect significantly the damage on the cotton bolls and the total damage of the fruit structures. The larva of $S$. frugiperda destroyed 3.78 fruit structures during its development. 


\section{INTRODUÇAOO}

0 algodoeiro (Gossypium spp!) produz a fibra textil natural mais importante do mundo, seja considerando-se - volume da produção, o valor monetário da mesma ou a multi plicidade de produtos que dele se origina. Constitui uma cul tura de grande importāncia econômica para muitos países. A pro dução mundial para o ano 1980/81 foi de 65,5 milhões de far dos, 500 mil fardos inferior à obtida em 1979/80. Entretanto, estimativas preliminares indicam elevação na produção para os anos seguintes (INSTITUTO DE ECONOMIA AGRICOLA, 1981).

O Brasil é um dos grandes produtores mundiais de algodão e entre os Estados produtores, destacam-se os do Paraná e São Paulo com uma produção prevista para o ano agrí cola 1981/82 de 591,3 e 517,2 mil toneladas de algodão em caroço, respectivamente, contribuindo assim com uma boa parcela para a economia do país (AGROANALYSIS, 1982).

Na tentativa de produzir economicamente mais por unidade de ārea, o cotonicultor enfrenta sérias dificuita 
des, pois grande parte dessa produção, é perdida devido a pra gas. A cultura do algodoeiro se situa entre as mais atacadas por insetos, que danificam todas as partes da planta, preferen cialmente as frutificações. REINOLDS et alii (1976), calcula ram que mais de $80 \%$ das perdas atribuídas às pragas do algodo eiro foram causadas por espécies que atacam as partes frutífe ras, dentre estas a spodoptera frugiperda (J.E.Smith, 1797).

A espécie em questão é polífaga alimentando-se de um grande nūmero de plantas cultivadas ou não, causando sem pre grandes prejuízos. Entretanto, os danos que as lagartas dessa espécie causam à cultura do algodoeiro ainda não foram devidamente pesquisados e a obtenção de dados que permitam re lacionar o nūmero dessas lagartas e a produtividade é cons derada imprescindível para determinação do seu nível de con trole. Também, pouco se sabe sobre os seus häbitos e os méto dos pelos quais elas poderiam ser controladas.

Desta forma, o presente trabalho foi desenvol vido no sentido de se verificar os danos decorrentes do ata que das lagartas de $S$. Grugiperda na produção e nas estrutü ras frutifferas das plantas de algodoeiro, bem como a biologia comparada em folhas de algodoeiro e milho em condições de la boratório, sendo necessário o conhecimento do seu potencial biōtico nessa gramínea, pois ela é cultivada na mesma ēpoca e geralmente próximo a cultura do algodoeiro. 
3.

\section{REVISAOO DE LITERATURA}

Värios foram os autores que se dedicaram ao es tudo de $S$. frugiperda sob os mais diversos aspectos. Embora seja uma importante praga de diversas culturas de expressão económica, não existem praticamente pesquisas com esse inse to, atacando a cultura do algodoeiro.

\subsection{Distribuição geográfica, plantas hospedeiras e época de ocorrência.}

A distribuição geogrāfica de $S$. frugiperda foi primeiramente relatada por LUGINBILL (1928), na América do Norte. Ele considerou esta praga como sendo de origem tropi cal, uma vez que seus centros de imigração localizam-se nos trōpicos. Esta teoria é reforçada por LABRADOR (1967) que mos trouser esta espécie de ampla distribuição na América Central e América do Sul. LEIDERMAN e SAUER (1953) apresentaram a dis tribuição geogrāfica da espécie na América do Sul e no Brasil.

LUGINBILL (1928) relatou que é frequente encon 
trar-se posturas de $S$. frugiperda em diferentes espēcies de plantas e apoiando-se nesse fato, caracterizou sua polifagia. 0 autor listou mais de 60 espécies de plantas como sendo hos pedeiras dessa praga.

Levantamentos de plantas hospedeiras de $S$. fru giperda foram feitos por vārios pesquisadores, tais como: DEW (1913), LUGINBILL (1928), COSTA LIMA (1950), FENTON (1952), LEIDERMAN e SAUER (1953), BIEZANKO et alii (1974), METCALF e FLINT (1965), LUCCHINI (1977).

LABRADOR (1967) mostrou que, na Venezuela, a in cidência desta espécie é variāvel de um ano para outro, mas que sua presença em cultivares de milho se faz principalmente nos meses chuvosos de maio a agosto. De maneira semelhante, DORESTE (1975), neste mesmo paîs, mostrou que a espécie é alta mente influenciada pela estação chuvosa, aparecendo em maio res quantidades nos meses de maio, junho e julho, diminuindo notadamente em agosto e setembro.

CARVALHO (1970) registrou o período de maior ocorrência da praga, de outubro a fevereiro em cinco municí pios do Estado de São Paulo. PARRA et alii (1971), também no Estado de São Paulo, mostraram que as condições ótimas para o desenvolvimento de $S$. Grugiperda, tais como temperatura eleva da e pouca umidade, ocorrem de um modo geral de outubro maio. LARA e SILVEIRA NETO (1977), estudando a flutuação populacional de noctuídeos pragas, na região de Jaboticabal, encontra ram uma população elevada dessa espécie no período compreendi 
do entre novembro e março com acme em dezembro.

SILVEIRA NETO et alii (1979) observaram a ocor

rência de $S$. frugiperda em Santa Maria, RS, nos meses de no vembro a julho com maior aumento de fevereiro a maio, e que a auséncia da praga nos meses de agosto a outubro, coincidiram com a dos meses mais chuvosos na região.

\subsection{Aspectos Biológicos}

2.2.1. Período de pré-oviposição, capacidade de postú ra e perĩodo de incubação.

Segundo observações de vārios autores

(DEW,

1913 ; LUGINBILL, 1928 e 1950; FONSECA, 1937 e 1942; HYNES, 1942; BERTELS e ROCHA, 1950; FENTON, 1952; LEIDERMAN e SAUER, 1953; SALAS, 1954; RUPPEL et alii, 1956; ETCHEVERRY, 1957; MARQUEZ et alii 1963/64; METCALF e FLINT, 1965; PENAGOS, 1974; ESCALANTE, 1974; LUCCHINI, 1977 e PATEL, 1981) os ovos de $S$. frugiperda são colocados em massa de camada simples ou vārias camadas sobrepostas. Verificaram a inda, o nūmero de camadas de ovos por: postura, bem como o nūmero de ovos existente em ca da massa.

As massas de ovos colocados pelas mariposas de S. frugiperda, segundo É́CHEVERRY (1957), AZEVEDO (1962) e BERTELS (1970), são cobertas de pelos e escamas provenientes do corpo da fêmea. DEW (1913) diz que as fémeas cobrem os ovos 
com fios parecidos com seda do seu próprio corpo. FONSECA (1937 e 1942) relatou ser esta cobertura feita por um materi al pulverulento acinzentado, proveniente do corpo da fémea. Segundo LUCCHINI (1977) e PATEL (1981), as massas de ovos são unidas entre sí e fixas ao substrato por meio de uma subs tituicão produzida pelas glāndulas coletéricas, e recobertas por pelos e escamas do corpo da própria fémea.

No Alabama, E.U.A., DEW (1913) estudou a biologia de $S$. frugiperda em condições de laboratōrio, à tempera tura de $78^{0} \mathrm{~F}\left(25,5^{0} \mathrm{C}\right)$ encontrando um período médio de pré oviposição de 1,5 dias. Tambēm observou que as mariposas põem de 160 a 700 ovos, usualmente à noite, sobre folhas de mi lho, algodoeiro, gramineas ou outros vegetais que sejam ali mento adequado às lagartas. o período de incubação foi, se gundo esse autor, em média, de 3 dias, variando de 2 a 4 di as, a depender da temperatura.

LUGINBILL (1928) relatou que durante os meses de julho e agosto o período de prē-oviposição foi em média 3,45 dias, constando que uma fêmea coloca, em média, 1.393 ovos durante o período de oviposição que durou de 4 a 17 dias. Ob servou que a maioria dos ovos foram postos durante os primei ros quatro e cinco dias, e que praticamente todos os ovos são férteis. O autor relatou ainda que, o período de incubação dos ovos depende basicamente das condições de temperatura, en quanto que a umidade desempenha um papel secundārio, obtendo para uma temperatura de $80^{0} \mathrm{~F}\left(26,7^{0} 0\right)$ e $69^{0} \mathrm{~F}\left(20,6^{0} \mathrm{C}\right)$, um perío 
do de incubação de 2 ou pouco mais de 4 dias, respectivamen te.

HYNES (1942) encontrou os seguintes valores médios: período de pré-oviposição 1,8 dias; período de oví posição 3,7 dias; número de ovos por postura 361; número de posturaspor fémea 6,5 . 0 período de incubação dos ovos foi de 2 a 3 dias.

BERTELS e ROCHA (1950) observaram que, em plan tas de milho as mariposas de $S$. frugiperda põem mais de 1.000 ovos, sendo a duração do período de incubação de 10 dias.

LEIDERMAN e SAUER (1953), estudando a fecun didade desta praga em condições não controladas ide laboratō rio, encontraram valores médios de $1.572,1.440$ e 1.670 ovos postos por fêmea, respectivamente,para os meses de fevereiro, março e maio, com um minnimo de 671 e um māximo de 2.680 ovos. Esses ovos apresentaram um perīodo de incubação de 2 dias em fevereiro e 5 dias em maio.

Segundo SALAS (1954), a média de ovos produzi dos pela S. frugiperda foi de 2.300, com o minimo de 656 e 0 máximo de 3.590 , apresentando um período de incubação de 2,63 dias.

Em observações realizadas no Chile, à tempe ratura de $150 \mathrm{C}$ e $220 \mathrm{C}$, ETCHEVERRY (1957) encontrou um perío do de prē-oviposição, respectivamente, de 7 e 3 dias. 0 núme ro total de ovos produzidos por fêmea variou de 4 a 60 em um 
período de postura que durou de 4 a 9 dias. Esses ovos apre sentaram um perīodo de incubação de 7 a 9 dias à $15^{0} \mathrm{C}$ e de 3 a 4 dias à $22^{0} \mathrm{C}$.

MARQ̨UEZ et alii $(1963 / 64)$ determinaram um pe ríodo de prē-oviposição e oviposição de 4 e 3 dias, respecti vamente. 0 período médio de incubação dos ovos foi de 4,27 dias à temperatura compreendida entre 21 e $22^{0} \mathrm{C}$ e de 2 dias à temperatura de 26,5 a $28^{0} \mathrm{C}$.

Quando os insetos foram criados em dieta arti ficial que continha como ingrediente bāsico germe de trigo, a uma temperatura de $80^{0} \mathrm{~F}\left(26,7^{\circ} \mathrm{C}\right)$ e fotoperíodo de 15,9 ho ras, RANDOLPH e WAGNER (1966) encontraram um período de incu bação, em média, de 2,2 dias. BAILEY e CHADA (1968) observaram uma duração para esse período de 3 dias a $26^{\circ} \mathrm{C}$ em dieta natu ral (folhas de sorgo). Em temperaturas menores $\left(22^{0} \mathrm{C}\right.$ ) esse período pode variar de 4 a 5 dias conforme monstraram as pes quisas de REVELO e RUAN (1964). Segundo este autor, o perío do de pré-oviposição variou de 2 a 3 dias.

BOWLING (1967), estudando a fecundidade de $S$. Grugiperda em dieta artificial a base de feijão, determinou que uma fêmea deposita, em média, 696 ovos com um período de incubação de 3 a 4 dias, à temperatura de $80 \pm 3^{0} \mathrm{~F}(26,7 \pm$ $\left(1,67^{0} \mathrm{C}\right)$ e umidade relativa de 85 a $90 \%$.

Em condiçōes de laboratōrio, com temperatura de $27^{\circ} \mathrm{C}$ e umidade relativa de $77 \%$, VELEZ e SIFUENTES (1967), determinaram um perïodo de pré-oviposição de 5 dias. As mari 
posas podem fazer 3 intervalos de postura durante o período de oviposição. Inicialmente elas colocam grupos de 10 a 20 ovos durante 3 dias consecutivos, paralizando a postura por um dia e voltando a ovipositar em grupos de 50 a 60 ovos. 0 período de incubação dos ovos foi de 4 dias.

Para LABRADOR (1967), a duração média do pe ríodo de incubação dos ovos foi de 2 dias, à temperatura de $30,2 \circ \mathrm{C}$.

ESCALANTE (1974) encontrou um período de prẹ oviposição em média de 6 dias, verificando que uma fémea prọ duziu de 40 a a 500 ovos, com um período de incubação de 12,5 dias para insetos criados a uma temperatura média de 10,080 C e umidade relativa de $67 \%$.

LUCCHINI (1977) trabalhou em condições de la boratório com temperatura de $25 \pm 10 \mathrm{C}$, umidade relativa de $70 \pm 5 \%$ e fotoperíodo de 12 horas, e encontrou uma duração de 4,4 dias para o período de pré-oviposição. O número total de ovos produzidos por fémea foi, em média, 2.449 com uma via bilidade de $91,22 \%$, relatando ainda que, uma postura contém, em média, 206 ovos e que o período de oviposição teve uma dura ção média de 7,8 dias. Foi observado também pelo autor, que a maioria dos ovos foi colocada nos trēs primeiros dias de pos tura; a partir daí, verificou um decréscimo gradativo, che gando praticamente a zero no fim do período de postura. 0 pe rỉodo de incubação foi de 3 dias.

KASTEN JR. et alii (1978) estudaram a biolo 
gia de $S$. frugiperda em condições de laboratōrio, à tempera tura de $27 \pm 2^{0} \mathrm{C}$, umidade relativa de $70 \pm 10 \%$ e fotoperíodo de 12 horas, e observaram os seguintes resultados quando os insetos foram criados em folhas de milho: período de pré-ovi posição: 2,8 dias; nümero mêdio de ovos por fêmea: 1.040,6; viabilidade de ovos: $87,1 \%$; período de incubação: 2,4 dias.

PATEL (1981), estudando a biologia de S. frue giperda em condições de laboratōrio à $28,9^{0} \mathrm{C}$ e $71,49 \%$ U.R. para a primeira geração e $24,54^{\circ} \mathrm{C}$ e $69,31 \%$ U.R. para a segun da geração, obteve em média, respectivamente, os seguintes re sultados: período de prē-oviposição 2,75 e 5,59 dias; perỉo do de oviposição 5,45 e 6,06 dias; perĩodo de pōs-oviposição 5,55 e 5,00 dias; nūmero de ovos por fémea 1.793 e 1.013; pẹ ríodo de incubação dos ovos 2 e 3 dias.

2.2.2. Estāgios de desenvolvimento do inseto.

As lagartas de $S$. frugiperda segundo DEW (1913), passam por 6 instares durante um período larval de 14 dias, à temperatura de $78^{0} \mathrm{~F}\left(25,5^{0} \mathrm{C}\right)$. A duração de cada înstar foi de: 109) 1,0 dia; 20) 1,50 dias; 30̣) 1,70 dias;49̣) 2,5 dias a 3,0 dias; 50 e e 60) 7 dias. A duração do período de prē-p $\underline{u}$ pa foi 1,1 dias, e o da pupa, em mëdia, 10 dias, variando de 3 a 16 dias.

SMITH (1921), em observações de campo,verificou que em plantas de alfafa o periodo larval de S. frugiperda teve 
uma duração de mais ou menos 23 dias, sendo que a fase de prē-pupa e pupa durou, respectivamente, 2 e 7 dias.

Para LUGINBILL (1928), as lagartas dessa especie passam por 6 ou 7 instares durante um periodo larval de 12,1 dias (nos meses de julho e agosto) e 29,7 dias (no mês de outubro). A duração média de cada ínstar larval foi de 2,0 a 3,$47 ; 1,40$ a 2,$25 ; 1,30$ a 2,$21 ; 1,35$ a 2,$63 ; 2,15$ a 4,$20 ; 3,90$ a 13,25 e 23,46 dias, respectivamente, para 0 prí meiro, segundo, terceiro, quarto, quinto, sexto e sétimo íns tares. 0 mesmo autor mencionou que a duração do estágio de pú pa é variável dependendo das condições ambientais em que se conduz o estudo, encontrando uma duração para esse período de 7 a 27 dias.

Quando as lagartas de $S$. frugiperda foram ali mentadas com folhas de milho em condições de laboratörio, HY NES (1942) verificou um período larval de 14 a 25 dias, sen do que,durante esse período, as lagartas passaram por 6 a 7 instares e cada instar durou de 2 a 3 dias. O período pré-pú pal foi de 2 a 3 dias e durante 8 a 11 dias ocorreu a emer gència dos adultos.

Em condições de campo, na cultura do milho, BERTELS e ROCHA (1950) encontraram um período larval de 21 a 28 dias, observando que as lagartas da referida espécie pre ferem solos arenosos para passarem a fase de pupa que teve uma duração de 14 dias.

FENTON (1952) observou que em plantas de mi 
Tho o periodo larval de $S$. frugiperda foi, em média, 10,9 dias e o período pupal, 9,6 dias. Verificou que as pupas se refü giavam no solo num casulo frouxo feito por partículas de so 10 e fio de seda. Quando o solo era compacto, o casulo se fi xava na base das plantas ou sob torrões de terra.

Para LEIDERMAN e SAUER (1953), as lagartas quando criadas em folhas de milho, passaram por 5 ou 6 ins tares durante um período larval de 25 dias nos meses de mar ço a abril e de 23 dias nos meses de abril a maio. 0 periodo de prē-pupa foi de 2 a 3 dias, e o período pupal variou, em média, de $11: 18$ e 19 dias, respectivamente, para os meses de fevereiro, abril e maio.

SALAS (1954) observou que as lagartas da especie em questão, quando alimentadas com folhas de milho, apre sentaram uma duração mēdia de 13,2 dias, passando por 4 ins tares larvais sendo o tempo médio para a duração de cada íns tar de: 2,$25 ; 1,58 ; 1,44$ e 1,53 dias. A duração do perỉodo de pupa foi, em média, de 9,9 dias para os machos e de 11 dias pa ra as fêmeas.

Para ETCHEVERRY (1957), as lagartas de S. fru giperda quando criadas em folhas de alfafa apresentaram um período larval de 30 a 35 dias e um período pupal de 18 a 22 dias quando a temperatura se encontrava à $15^{\circ} \mathrm{C}$. No entanto, à temperatura mais alta $\left(22_{-}^{0} \mathrm{C}\right)$, o período larval foi de 12 a 24 dias com um periodo pupal entre 8 e 15 dias. 
que as lagartas de $S$. frugiperda quando alimentadas com fo lhas de milho, viveram,em média, 11 dias, passando por 6 íns tares com as seguintes durações: 10) 2,0 dias; 20) 1,20 di as; 30) 1,04 dias; 40) 1,25 dias; 50) 1,33 dias; 60) 1,0 dia. Para a fase de pupa, encontrou uma duração mēdia de 8 dias, com uma amplitude entre 4,33 e 10,5 dias.

\section{Em estudos de laboratório, MARQUEz et alii} (1963/64) encontraram que as lagartas da espécie em questão viveram em média 22,43 dias, com uma duração média para a fase de pupa de 8,80 dias, quando criadas em folhas de milho. Em grãos de milho o período larval durou,em média,20,56 dias e o período pupal, em média, 8,45 dias.

R.ANDOLPH e WAGNER (1966) estudaram o ciclo bi ológico de $S$. frugiperda em quatro gerações, em insetos cria dos em dieta artificial à base de germe de trigo, em tempe ratura de $80^{0} \mathrm{~F}\left(26,7^{\circ} \mathrm{C}\right)$ e fotoperíodo de 15,9 horas. Verifi caram que as lagartas passaram por 6 instares larvais com uma duração para a fase de pupa, em média, de 7,86 dias.

LABRADOR (1967) relatou que lagartas desta e $\underline{s}$ pécie apresentaram um perīodo larval, em média, de 9 dias quan do alimentadas com folhas de milho, à temperatura de $30,2^{0} \mathrm{C}$. As lagartas, quando recebiam uma alimentação abundante, passa vam por 6 instares e quando esta era limitada, apresentavam 7 instares. 0 periodo pupal encontrado foi, em média, de 6 dias.

Em condições de laboratōrio, à temperatura de $80 \pm 3^{0} \mathrm{~F}\left(26,7 \pm 1,67^{0} \mathrm{C}\right)$ e umidade relativa de 85 a $90 \%$, BOW 
LING (1967) encontrou um período larval médio de 19,2 dias, variando de 16 a 25 dias para as lagartas criadas em dieta artificial à base de feijão. A duração média para a fase de pupa foi de 12 dias com um mínimo de 9 dias e o máximo de 18 dias, e um peso médio para as pupas de 397 e $466 \mathrm{mg}$, respec tivamente, para machos e fémeas.

Segundo VELEZ e SIFUENTES (1967), as lagartas de $S$. frugiperda quando criadas em folhas de milho à tempera tura de 270 C e umidade relativa de $77 \%$ apresentaram uma dura ção de 21 a 22 dias passando por 3 instares,e 7 dias para a fase de pupa.

Na Guatemala, PENAGOS (1974), em observações de campo, relatou que, em plantas de milho, as lagartas de $S$. frugiperda passaram por 5 estágios larvais, e uma fase de pu pa de 8 a 10 dias.

LUCCHINI (1977), trabalhando a uma temperatü ra de $25+10 \mathrm{C}, 70 \pm 5 \%$ U.R. e fotoperíodo de 12 horas, ob servou que lagartas criadas em folhas de milho, passaram por 7 instares num período larval de $14,67 \pm 0,03$ dias. 0 tempo de duração para cada ínstar foi: 2,00 $\pm 0,00 ; 2,03 \pm 0,04 ; 1,35$ $\pm 0,09 ; 1,93 \pm 0,07 ; 2,04 \pm 0,07 ; 2,26 \pm 0,09$ e 3,07 $\pm 0,07 \mathrm{~d} \underline{i}$ as. A fase de pré-pupa durou, em média, 2 dias e a de pupa 11,8 dias para os machos e 10,17 dias para as fèmeas. 0 peso médio das pupas foi de $224,56 \mathrm{mg}$.

KASTEN JR. et alii (1978) observaram que as lagartas dessa espécie viveram,em mēdia, 13,67 dias quando cria 
das em folhas de milho. Relataram também, que a duração, peso e viabilidade para a fase de pupa foram, respectivamente de: 7,96 dias, 0,224 g e 91,3\%, em condições de laboratório à $27 \pm 2{ }^{\circ} \mathrm{C}, 70 \pm 10 \%$ U.R. e fotoperiodo de 12 horas.

PATEL (1981) constatou para essa espécie, quan do criada: em folhas de milho em 2 gerações, à temperatura de 28, 0990 e 24,549C, com uma umidade relativa de $71,49 \%$ e $69,31 \%$, que a duração do perĩodo larval foi de 11,68 e 16,80 dias, respectivamente. As lagartas nas duas gerações estuda das apresentaram 6 instares com uma duração para cada instar

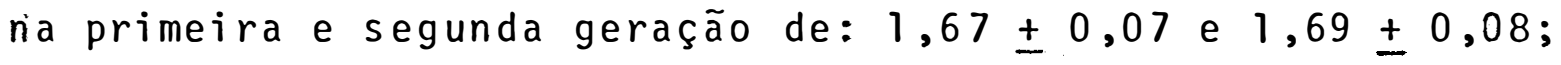
$1,66 \pm 0,05$ e $2,14 \pm 0,07 ; 1,42 \pm 0,06$ e $2,19 \pm 0,07 ; 1,78$ $\pm 0,05$ e $2,51 \pm 0,11 ; 2,03 \pm 0,05$ e $3,16 \pm 0,08 ; 3,20 \pm 0,06$ e $5,32 \pm 0,11$ dias. A duração da fase de prē-pupa foi, em mé dia, de 1,04 dias para a primeira geração e 1,17 dias para a segunda geração. A duração e viabilidade para o estāgio de pupa na primeira e segunda geração foi,em mēdia, de: 9,2 dias e $96,43 \% ; 13,44$; di.a.s e $95,13 \%$.

2.2.3. Longevidade dos adultos e nümero de gerações anuais.

DEW (1913) observou que a longevidade dos aduI tos de $S$. frugiperda variou de 4 a 8 dias, e que, em condições de campo ocorreram 5 gerações durante os meses de maio a se tembro. A alimentação e a temperatura são fatores que influ enciam a longevidade dos adultos (LUGINBILL, 1928). 0 mesmo 
autor verificou que os adultos de $S$. frugiperda quando al $\underline{i}$ mentados com uma solução de mel ou açūcar diluido em àgua, viveram,em média, 13,3 dias variando de 6 a 23 dias, mas quando não recebiam alimentação a duração de vida média en contrada foi de 4,36 dias, variando de 3 a 6 dias. Relatou que nos Estados do Golfo do México, E.U.A., a espécie apre sentou 6 gerações anuais.

HYNES (1942) determinou que a longevidade dos adultos de $S$. Grugiperda variou entre 3 e 8 dias. Para FEN TON (1952) esta duração foi de 14 a 21 dias, podendo haver de 9 a 11 gerações por ano nos Estados do Golfo do México, mas ocorrendo apenas uma geração nos Estados do Norte.

LEIDERMAN e SAUER (1953) citaram a provável ocorrência de 5 gerações anuais em Campinas (SP), sendo, em condições de laboratório, a longevidade dos adultos, em média, de 13 dias, variando de 6 a 24 dias durante os meses de abril e maio.

A longevidade dos adultos de $S$. frugiperda oriundos de folhas de alfafa,pode durar 16 dias à $150 \mathrm{C}$ e 10 dias à 220̣ (ETCHEVERRY, 1957). Estudando a mesma espécie, ES TRADA (1960) determinou que o tempo médio de vida dos adul tos fóide 4 dias', com um tempo máximo de 6,3 dias, verifican do que,em plantações de milho na Nicarágua, podem ocorrer até 12 gerações anuais. Quando oriundos respectivamente de folhas e grãos de milho, MARQUEZ et alii (1963/64) encontra ram uma duração de vida para os adultos de 6,6 e 7 dias em 
condições de temperatura oscilando entre $21^{\circ} \mathrm{C}$ e $22^{\circ} \mathrm{C}$ e $26^{\circ} \mathrm{C}$ e $28^{\circ} \mathrm{C}$. Para LABRADOR (1967), a duração desse período foi de mais ou menos 6 dias, quando os adultos eram alimentados com uma solução de mel a $4 \%$.

Quando os adultos de $S$. frugiperda foram cria dos à temperatura de $27^{\circ} \mathrm{C}$ e umidade relativa de $77 \%$, VELEZ e SIFUENTES (1967) no México, determinaram uma duração média de 15 dias, verificando ainda que, durante os trēs meses de desenvolvimento do milho a praga apresentou 3 gerações. Quan do a alimentação fornecida era uma solução de mel diluĩdo em àgua à temperatura média de $10,8^{\circ} \mathrm{C}$ e umidade relativa de $67 \%$, ESCALANTE (1974) determinou que a longevidade desses adultos era de 10 a 15 dias.

De acordo com LUCCHINI (1977), a longevidade dos machos $(21,1$ dias) foi bem maior que a das fémeas $(12,4$ dias) quando os adultos foramalimentados com mel diluído em āgua $(1: 4)$ à temperatura de $25 \pm 1^{\circ} \mathrm{C}$, umidade relativa $70 \pm$ $5 \%$ e fotoperiodo de 12 horas. Para KASTEN JR. et alii (1978), a duração média de vida dos adultos de $S$. frugiperda, quando criados com uma solução açucarada 10\% à temperatura de $27 \pm$ $2^{\circ} \mathrm{C}$, umidade relativa de $70 \pm 10 \%$ e fotoperíodo de 12 horas, foi de 7,75 dias para os machos e 7,85 dias para as fémeas.

Segundo PATEL (1981), a longevidade dos adu] tos da referida espécie quando criados com uma solução de mel a $10 \%$ foi de 13,26 dias para machos e fémeas na primeira ge ração $\left(28,09^{\circ} \mathrm{C}\right.$ e $\left.71,99 \%\right)$ e de 15 e 16,65 dias para machos e 
fêmeas, respectivamente, na segunda geração $\left(24,54^{\circ} \mathrm{C}\right.$ e $\left.69,31 \%\right)$.

\subsection{Danos de Spodoptera spp. em algodoeiro}

Vārios autores tēm demonstrado que o ataque de S. frugiperda causa diminuição na produção de diversas cultú ras (HENDERSON et alii, 1966; SIFUENTES, 1967; CARVALHO, 1970; STARKS e BURTON, 1979 e CRUZ e TURPIN, 1982), no en tanto, autores como DEW (1913), COSTA LIMA (1950), FURR e CALHOUN (1952), HUNTER E BENITEZ (1964), SQUIRE (1972), SALAS (1974) e ISA (1977), encontraram esta espécie com relatí va frequéncia em plantas de algodoeiro, nos países onde se cultiva esta malvacea. Porēm, não foram encontrados na litera tura dados sobre os prejuĩzos que esta praga causa em função de sua população, na cultura do algodoeiro.

CANDIA (1971), fazendo um levantamento de prä gas que atacam a cultura do algodoeiro na Bolivia, através da coleta de lagartas no campo,encontrou que $20,2 \%$ das lagar tas amostradas eram de $S$. frugiperda. Nas Honduras, HOWEEL JR. (1975), estudando o complexo de pragas do algodoeiro con siderou esta espécie como sendo uma das principais pragas dessa cultura. No Brasil, PICCININ e LARA (1977), verificando a porcentagem de ocorrência de lagartas das maçãs do algodo eiro, observaram que $92,9 \%$ da população amostrada era de $S$. frugiperda.

Esta espécie foi considerada por FENTON (1952), 
como sendo uma praga de primeira ordem, devido a grande den sidade de lagartas e pela alimentação contínua e voraz nas culturas atacadas. Embora ela possa alimentar-se das estrutu ras frutíferas das plantas causando perfurações, é incluída no grupo dos insetos desfolhadores devido à destruição das folhas, ramos tenros e pequenas plantas. 0 mesmo autor men cionou que, quando o ataque ocorrer na cultura do algodoeiro, os danos causados são variáveis, mas nenhuma parte da plan ta está livre de ser danificada.

Um dano comum causado pelas lagartas dessa es pécie na cultura do algodoeiro, segundo PYENSON (1938), LLㅌ NOS (1940) e HERRERA (1961), é o corte das plāntulas rente ao solo. Esse mesmo tipo de dano foi encontrado na cultura do milho por SALAS (1964), COSTILLA e MERCADO (1968) e ESCALAN TE (1974).

Vários autores (LUGINBILL, 1950; FENTON 1952 e HOWEEL JR., 1978) observaram plantações de algodoeiro seve ramente atacadas por lagartas de $S$. frugiperda, verificando que o dano mais freqüente era o corte dos ponteiros das plan tas. No entanto, HAMBLETON (1939) e SQUIRE (1972) encontraram lagartas dessa espécie alimentando-se de folhas.

HERRERA (1961) constatou a presença dessa praga atacando plantas bem desenvolvidas, seccionando-as ao nível do solo.

HUNTER e BENITEZ (1964) na Colômbia, SALAS (1974) na Venezuela e CARVALHO e CARVALho (1939) no Brasil, encontraram lagartas de $S$. Grugiperda atacando botões flo 
rais do algodoeiro. LLANOS (1940) mencionou que se o ataque ocorrer no começo da frutificação, ele é direcionado às maçãs perfurando-as e alimentando-se do seu conteúdo. 0 mesmo autor observou que os danos causados às maçãs por esta espécie assemelham-se àqueles de Heliothis obsoleta F.

PEREIRA (1971) encontrou lagartas dessa espécie em diversos estágios de desenvolvimento alimentando - se de botões florais, flores e sobretudo das maçãs, localizadas no meio e na parte mais baixa das plantas de algodoeiro. 0b servou ainda, que nos primeiros estágios de desenvolvimento as lagartas alimentam-se das brácteas para posteriormente passarem às maçãs, que são perfuradas através de orifícios irregulares, e que após penetrarem em maçãs mais desenvolvi das, alí permanecem todo o período larval e só saem para em pupárem no solo.

COVARRUBIAS e PACHECO (1970) procuraram estabe lecer os danos causados pelos insetos que destroem os botões florais, as flores e as maçãs no decorrer do ciclo vegetati vo do algodoeiro através da remoção manual dessas estruturas em diferentes níveis quantitativos e em diferentes épocas de desenvolvimento da planta. Os danos foram simulados para qua tro níveis: $0: 33 ; 66$ e $100 \%$ a partir da terceira semana após o aparecimento dos primeiros botões florais e se prolongaram até a sexta semana. Os resultados demonstraram que a maior produção de botões florais ocorreudurante a quarta e quinta 
semanas do início do florescimento e durante a sētima e oita va semanas, o algodoeiro alcança a māxima produção de flores e maçãs. Em relação aos efeitos dos danos sobre o rendimento das plantas, mostraram que um dano de $100 \%$ até a oitava sema na apōs a emergēncia das plantas não reduz o rendimento, mas que a partir da nona, um dano de $100 \%$ e bastante critico. 0 dano de $66 \%$ é elevado a partir da décima primeira semana e particularmente na décima segunda, enquanto que, um dano de $33 \%$ se reflete a partir da décima primeira semana. Até este perỉodo em que se eliminaram 5 maçãs e 21 a 22 botões flo rais por planta, o algodoeiro restitui a carga sem problemas, mas, a partir da décima segunda semana apōs a germinação, em que se eliminaram 14 maçãs e 14 a 15 botões florais, os da nos foram de $100 \%$.

SANTOS e MARUR (1980) simularam os danos oca sionados pelas pragas destruidoras de estruturas frutiferas, nos níveis de 33,66 e $100 \%$, retirando-se os órgãos de frutifi cação ao longo dos ramos, a partir de 50 dias apōs a emergên cia das plantas sendo continuadas em intervalos de 10 dias atē a formação do primeiro capulho. Observaram uma redução na produção a partir dos 85 dias para os três níveis simula dos, quando o plantio era realizado dentro da época recomen dada. Em algodoeiro plantado tardiamente,os danos na produ ção se fizeram sentir a partir dos 60,70 e 85 dias nos ni veis de 100,66 e $33 \%$, respectivamente.

A cultura do algodoeiro pode ser seriamente 
danificada por lagartas de $S$. frugiperda, quando cultivada nas proximidades de plantas hospedeiras (FENTON, 1952; ANTHO NY e BRAV0, 1970). De acordo com estes autores, os plantios de algodoeiro que não recebem um controle eficiente de plan tas daninhas ou quando essa cultura está consorciada com a do milho, ou de outras gramīneas, poderá ocorrer um aumento excessivo da pupulação dessa praga sobre a cultura do algodo eiro, podendo atingir um nível de dano econômico.

LLANOS (1940) afirmou que culturas intercalares com o algodoeiro favorecem o desenvolvimento de $S$. frugiperda.

Outras espécies de spodoptera tambēm atacam a cultura do algodoeiro causando danos consideráveis.

Spodoptera exigua (Hübner, 1808) foi repor tada pela primeira vez na Califórnia, E.U.A., em 1876. Segun do TAYLOR (1931), WENE e SHEETS (1961), FYE e CARRANZA (1973), DUARTE et alii (1974) e COBB e BASS (1975) esta espécie tem se tornado uma das principais pragas de importāncia económi ca para a cultura do algodoeiro. TAYLOR (1931) verificou es ta praga desfolhando as plantas de algodoeiro no inicio de desenvolvimento, necessitando as vezes de um replantio. No sul do Arizona WENE e SHEETS (1961), encontraram uma infesta ção de até 60 lagartas por planta de algodoeiro, atacando preferencialmente as folhagens e em seguida os botões flo rais e maçãs imaturas, provocando nessas um dano similar ao causadó pelas lagartas de Heliothis zea (Boddie, 1850). Ve rificaram também, que a $S$. exigua pode provocar o corte dos 
ponteiros em plantas mais desenvolvidas. DUARTE et. alii (1974) observaram que as lagartas desta espécie causam danos a esta cultura por 3 semanas, período em que passam por 5 es tágios larvais. Além de causarem o desfolhamento das plantas, atacam os botões florais, permitindo a entrada de outros orga nismos nas lesões, afetando seriamente as estruturas.

No Mississipi e Delta, E.U.A., a Spodoptera ornithogalli (Guenée, 1852), foi reconhecida como uma das principais pragas do algodoeiro, causando danos principalmen te às plantas no início de desenvolvimento ou perfurando o caule do algodoeiro mais desenvolvido (LOWRY e CALHOUN, 195?).

No Egito, EL-SAADANY (1973) e KHALIFA et alii (1974) relataram.ser a spodoptera littoralis (Boisduval, 1833), uma espécie polîfaga, porém seu hospedeiro preferido é o algodoeiro. Segundo REYNOLDS et alii (1975), essa especie é uma das mais importantes pragas das maçãs do algodoei ro em Israel.

No Brasil, a população de Spodoptera eridania (Cramer, 1782) raramente atingia niveis que causassem danos à agricultura, entretanto, nos ūitimos anos os prejuizos cau sados por este inseto tem aumentado consideravelmente em al gumas regiões do.Estado de São Paulo, principalmente em cul turas de soja e algodoeiro (PARRA et alii 1977). Os mesmos autores estudaram a biologia comparada dessa espécie em fo lhas de soja da cultivar Santa Rosa e em folhas de algodoei ro da cultivar IAC-17 e observaram um encurtamento do ciclo quando o inseto foi criado em algodoeiro, bem como uma maior 
capacidade de multiplicação nesse substrato alimentar, sugerindo uma maior adaptabilidade da praga a essa cultura. 


\section{MATERIAL E METODOS}

3.1. Experimentos de Laboratōrio

3.1.1. Biologia comparada de $s$. frugiperda em folhas de algodoeiro e de milho

0 presente trabalho foi desenvolvido nos labo ratōrios de Biologia, do Departamento de Entomologia ESALQUSP, em Piracicaba, à temperatura de $25 \pm 2{ }^{\circ} \mathrm{C}$, umidade relati va de $60 \pm 10 \%$ e fotoperiodo de 14 horas.

Os insetos utilizados nessa pesquisa foram ob tidos de colônias mantidas, no Departamento de Entomologia da ESALQ, em dieta artificial proposta por BOWLING (1967) e adap tada por KASTEN JR et alii (1978) para as nossas condições (Tabela 1); o método de preparo, foi aquele descrito por PARRA (1979). A partir da postura de laboratório foram separados dois grupos de 60 lagartas recém-eclodidas, sendo mantidas, respectivamente, em folhas de milho e de algodoeiro. 
Tabela 1 - Composição da dieta para S. frugiperda (KASTEN JR. et alii, 1978).

Feijão 'Rosinha'

Levedura

Ácido ascōrbico

Metil parahidroxibenzoato.

(nipagin) $\ldots \ldots \ldots$

$1,0 \mathrm{~g}$

Ācido sōrbico

$0,5 \mathrm{~g}$

Formal deído

Agar (+ $250 \mathrm{~m}]$ de āgua

$12,0 \mathrm{~g}$

Āgua

$375,0 \mathrm{ml}$

OBS.: Esta quantidade é suficiente para 80 recipientes de criação. 
3.1.1.1. Aspectos biológicos estudados

A biologia do inseto, foi estudada nos dois subs tratos alimentares sendo observados os seguintes parâmetros biológicos, durante uma geração:

1. Fase do 0vo.

1.1. Perĩodo de incubação

1.2. Viabilidade

2. Fase de lagarta

2.1. Duração total

2.2. Duração de cada instar

2.3. Nümero de instares (determinado atra vés de medição da cāpsula cefālica)

2.4. Peso das lagartas no máximo desenvolvi mento

2.5. Viabilidade

3. Fases de pré-pupa e de pupa

3.1. Duração da fase de pré-pupa

3.2. Viabilidade da pré-pupa

3.3. Duração da fase de pupa

3.4. Viabilidade pupal

3.5. Peso das pupas

3.6. Razão sexual (calculada através da fōr mula: $\left.\quad r s=\frac{q}{q+\sigma^{\prime}}\right)$ 
4. Fase adulta

4.1. Perĩodo de pré-oviposição

4.2. Perĩodo de oviposição

4.3. Perĩodo de pós-oviposição

4.4. Número de ovos por fémea

4.5. Número de ovos por postura

4.6. Nümero de posturas por fémea

4.7. Longevidade dos adultos

4.8. Ciclo evolutivo (ovo-adulto)

3.1.1.2. Técnica de criação de $S$. frugëperda

As lagartas recém-eclodidas foram individual $\underline{i}$ zadas em tubos de vidro (devido ao canibalismo), previamente esterilizados, com dimensões de $2,5 \mathrm{~cm}$ de diâmetro e $8,5 \mathrm{~cm}$ de comprimento e alimentadas com folhas de algodoeiro da cul tivar IAC-17 e com folhas de milho provenientes do hibrido HMD-7974. Os tubos de criacão foram tampados com algodão hidrófilo e mantidos em suporte de madeira. 0 alimento fornecido às lagartas do material fecal, para evitar problemas de contaminacão e de qualidade do alimento fornecido. Ao atingi rem o $\bar{u}$ timo instar, as lagartas foram pesadas diariamente em balança eletrōnica de precisão, modelo SAUTER, com aproxima cão de até centésimos de grama, para determinacão do peso no māximo desenvolvimento.

Dez lagartas de cada tratamento foram utiliza- 
das para medição diāria da cápsula cefálica, através de uma ocular graduada BAUSH \& LOMB, acoplada a um microscópio este reoscópio WILD MAA, com a finalidade de se determinar o núme ro de instares e a duração de cada instar.

A fase de pré-pupa foi considerada a partir do dia em que as lagartas não mais se alimentavam.

As pupas obtidas foram transferidas para ou tros tubos, tampados com algodão hidröfilo e, após 24 horas de idade, foram "sexadas" (BUTT e CANTU, 1962) e pesadas.

observações diārias permitiram determinar os períodos e viabilidades larvais, pré-pupais e pupais.

Para as observações dos períodos de pré-ovipo sição, oviposição, pōs-oviposição, longevidade dos adultos, razão sexual, nūmero de posturas por fêmea, nümero de ovos por postura e o total médio de ovos por fémea e sua viabili dade nos dois substratos estudados, foram individualizados casais oriundos de ambos os substratos. Estes casais eram formados por insetos que emergiam no mesmo dia, sendo obser vados 13 casais provenientes de algodoeiro e 15 casais do mi 1ho. Foram colocados em gaiolas cilindricas de arame de 18 cm de diāmetro e revestidas com tela de nylon e com as suas extremidades fechadas com placas de Petri de $16 \mathrm{~cm}$ de diāme tro, sendo as paredes internas da gaiola revestidascom uma folha de papel jornal para as fêmeas ovipositarem. Estes adul tos eram alimentados com solução de mel à 10\%, colocada em copinhos de plástico incolor de capacidade de $25 \mathrm{ml}$, forne 
cida por capilaridade, através de um pavio de algodão (rolo dental "Johnsons"), embebido no líquido. Para não haver pro blemas de fermentação, esse alimento era trocado diariamente.

Os ovos eram retirados da gaiola com auxílio de um pequeno pincel embebido em àgua, e contados em microscōpio estereoscópio. o período de incubação e viabilidade desses o vos para algodoeiro e milho foram determinados colocando - se 20 ovos, por postura, em placas de Petri de $10 \mathrm{~cm}$ de diāmetro por $2,0 \mathrm{~cm}$ de altura, forradas com papel de filtro umedecido, e fechadas com outra de igual diâmetro, sendo o conjunto veda do através de uma fita adesiva. o nūmero de lagartas eclodi das foi registrado através de observações diārias.

Os resultados obtidos para as diferentes fases do ciclo biológico de $S$. frugiperda nas duas condições estuda das foram submetidos à anālise de variāncia, sendo as mēdias comparadas pelo teste $t$, ao nível de $5 \%$ de probabilidade.

Para a anālise da razão sexual foi utilizado o tes te qui-quadrado $\left(x^{2}\right)$

\subsection{Experimentos de campo}

3.2.1. Determinação dos efeitos de dfferentes niveis de infestação da lagarta de $s$. Srugiperda na produção do algodoeiro.

3.2.1.1. Local, época, cultivar e tratos cultu rais 
o experimento foi desenvolvido numa ārea de $2.000 \mathrm{~m}^{2}$ do Departamento de Entomologia da Escola Superior de Agricultura "Luiz de Queiroz", da Universidade de São Paulo, Piracicaba, no período compreendido entre 28/11/80 e 07/05/81.

A cultivar de algodão utilizada foi a IAC - 17, semeada no dia $28 / 11 / 1980$, em linhas espaçadas de $1,0 \mathrm{~m} .0$ des baste foi realizado 30 dias após a germinação deixando-se 0,20 m entre plantas na linha.

O solo no local do experimento foi classifica do como Regossol, sērie Luiz de Queiroz. Baseando-se na sua anālise (Tabela 2) foram realizadas duas adubações; uma na é poca do plantio $\left(10 \mathrm{~kg} \mathrm{~N} ; 60 \mathrm{Kg} \mathrm{P}_{2} 0_{5}\right.$ e $\left.70 \mathrm{~kg} \mathrm{~K} \mathrm{~K}_{2} / \mathrm{ha}\right)$ e a ou tra em cobertura aos 45 dias após a germinação das plantas ( 40 $\mathrm{kg} \mathrm{N} / \mathrm{ha})$.

3.2.1.2. Condução do experimento, delineamento experimental e tratamentos.

Os dados de preçipitação pluviométrica e tem peratura do ar referente ao período do experimento, foram ce didos pela Estação Agrometeorológica do Departamento de Físi ca e Meteorologia da ESALQ/USP, Piracicaba, situada a $200 \mathrm{~m}$ do local do experimento (Apêndice 1 ).

Para impedir o ataque de outras pragas que vi essem a ocorrer na cultura, foi idealizado um esquema de pre venção através da aplicação de inseticidas quando necessārio. 
Para o controle dos àcaros branco e rajado, utilizou-se o pro duto Dicofol na dosagem de $350 \mathrm{ml}$ do ingrediente ativo por he $\underline{c}$ tare. Para evitar o aparecimento de lagarta rosada e do cur $\underline{\underline{L}}$ queré foram feitas trēs aplicações do defensivo Decamethrin na dosagem de $\log$ do ingrediente ativo por hectare.

0 delineamento estatístico foi o de blocos ao acaso, com 4 tratamentos e 5 repetições. Cada parcela cons tou de 2 linhas de $2 m$ de comprimento com um total de 8 plan tas por parcela. Foram utilizados os seguintes niveis de infestacão: $0,1,2$ e 4 lagartas por planta, sendo que cada $n \hat{i}-$ vel constituiu um tratamento. As infestacões artificiais, onde lagartas do terceiro instar eram colocadas sobre as folhas, foram feitas em plantas de algodoeiro com 75 e com 95 dias após a germinação. Para os diferentes níveis e épocas de infestação, observaram-se os seguintes paràmetros:

1. Produção (em gramas);

2. Número de ponteiros cortados;

3. Número de pupas encontradas.

As lagartas utilizadas neste experimento foram criadas no laboratörio, individualmente, em tubos de vidros de $2,5 \times 8,5 \mathrm{~cm}$. A alimentação destas lagartas éra trocada dią riamente, e consistia de folhas novas de algodoeiro. 
Apōs a infestação, as plantas de algodoeiro em todos os tratamentos, foram envolvidas por um saco telado de nylon preso à base das plantas, para não permitir a en trada de outros insetos nem a saída das lagartas (Figura 1).

Durante todo o período de atividade das lagar tas nas plantas de algodoeiro, foram realizadas observações diārias para avaliar o nūmero de ponteiros cortados nas duas épocas de infestação. Na observação final, foi contado o nū mero de pupas resultantes nos tratamentos com $1 ; 2$ e 4 lagar tas por planta.

Com a finalidade de se relacionar, época de infestação com a produção do algodoeiro foram realizadas du as colheitas manuais de algodão em caroço de todas as plan tas situadas na parte útil de cada parcela em 25/03/1981 e $05 / 05 / 1981$, respectivamente.

A pesagem do algodão foi feita em balança SAR TORIUS com aproximação de até centēsimos de grama.

Os dados obtidos de produção, nümero de pon teiros cortados, bem como, o nūmero de pupas encontradas de correntes das duas épocas de infestação, relacionados com os diferentes tratamentos, foram submetidos à anālise de variān cia pelo teste $F$ ao nível de $1 \%$ de probabilidade. 
Tabela 2 - Anālise do solo no local do experimento*.

\begin{tabular}{|c|c|c|c|c|c|c|c|}
\hline \multirow[b]{2}{*}{$\mathrm{pH}$} & \multirow{2}{*}{$\begin{array}{l}\text { Carbono } \\
\text { Orgānico }\end{array}$} & \multicolumn{2}{|c|}{ Teor trocāvel e } & \multicolumn{4}{|c|}{ niliequivalentes $/ 100 \mathrm{~g}$ de terra } \\
\hline & & $\begin{array}{c}\text { Fósfo } \\
\text { ro }\end{array}$ & $\begin{array}{c}\text { Potās } \\
\text { sio }\end{array}$ & Cálcio & $\begin{array}{c}\text { Magne- } \\
\text { sio }\end{array}$ & Aluminio & $\begin{array}{l}\text { Hidro } \\
\text { gênio }\end{array}$ \\
\hline & $\%$ & $\mathrm{PO}_{4}^{-3}$ & $k^{+}$ & $\mathrm{Ca}^{2^{+}}$ & $\mathrm{Mg}^{2}$ & $A T^{3}$ & $\mathrm{H}^{+}$ \\
\hline 5,4 & 0,81 & 0,02 & 0,08 & 2,15 & 0,36 & 0,17 & 4,70 \\
\hline
\end{tabular}

* FONTE: Departamento de Solos, ESALQ-USP, Piracicaba, SP, 1980.

\subsubsection{Estruturas frutiferas do algodoeiro danifica dás por lagartas de $S$. frugiperda em diferen tes épocas de desenvolvimento da cultura.}

0 experimento visou determinar o nūmero de es truturas de frutificação do algodoeiro danificadas pelas la gartas de $S$. Grugiperda em trés épocas de desenvolvimento da cultura.

A cultivar de algodoeiro utilizada foi a IAC17, semeada em vasos de sacos plásticos no dia 20/10/1981, num total de 45 plantas, sendo uma por vaso.

Os dados de precipitação pluviométrica e tem peratura do ar, referente ao ano de 1981, encontram-se no Apêndice 2 .

Para um bom desenvolvimento das plantas foram realizados todos os tratos culturais necessários. 
0 delineamento estatístico utilizado foi in teiramente casualizado com 3 tratamentos e 5 repetições, para danos equivalentes ao ataque de 0,1 e 2 lagartas por plan ta em trés épocas de desenvolvimento do algodoeiro, ou seja, aos 85, 100 e 115 dias apōs a germinação.

A escolha da idade das plantas para realiza ção das infestações foi baseada em resultados obtidos por outros autores (COVARRUBIAS e PACHECO, 1970; SANTOS, 1977 e BERTOLOTI, 1978), que relataram ser durante esse período a época em que, a cultura do algodoeiro alcança o máximo em produção de botões florais, flores e maçãs.

As trēs infestações artificiais para os três tratamentos em questão foram realizadas com lagartas do prí meiro instar para avaliar os danos provocados pelas mesmas durante todo o período de atividade das lagartas.

Para conhecer o estado fenológico das plan tas no momento em que foram ocasionados os danos, contava se o número de estruturas de frutificação. Em seguida colo cavam-se as lagartas nos ponteiros das plantas e logo após, estas eram envolvidas por um saco telado de nylon, preso à base das plantas, conforme foi descrito no item 3.2.1.2. (Figura 1). Diariamente, co letavam-se os botões florais, flores e maçãs derrubadas, anotan do-se quantas eram danificadas pelas lagartas. Também, contavam-se as maçãs perfuradás que permaneciam na planta.

0 período de verificação diāria se completą va quando a lagarta passava ao estágio de pupa. 
Para os cālculos da anālise estatística os vạ lores obtidos foram transformados em arc sen $\sqrt{\%}$. obtidosos dados de infestação para as trēs épocas de desenvolvimento do algodoeiro, procedeu-se a anālise de variāncia através do teste $F$ ao nivel de $1 \%$ de probabilidade a fim de verificarem as possiveis diferencas estatisticas existentes.

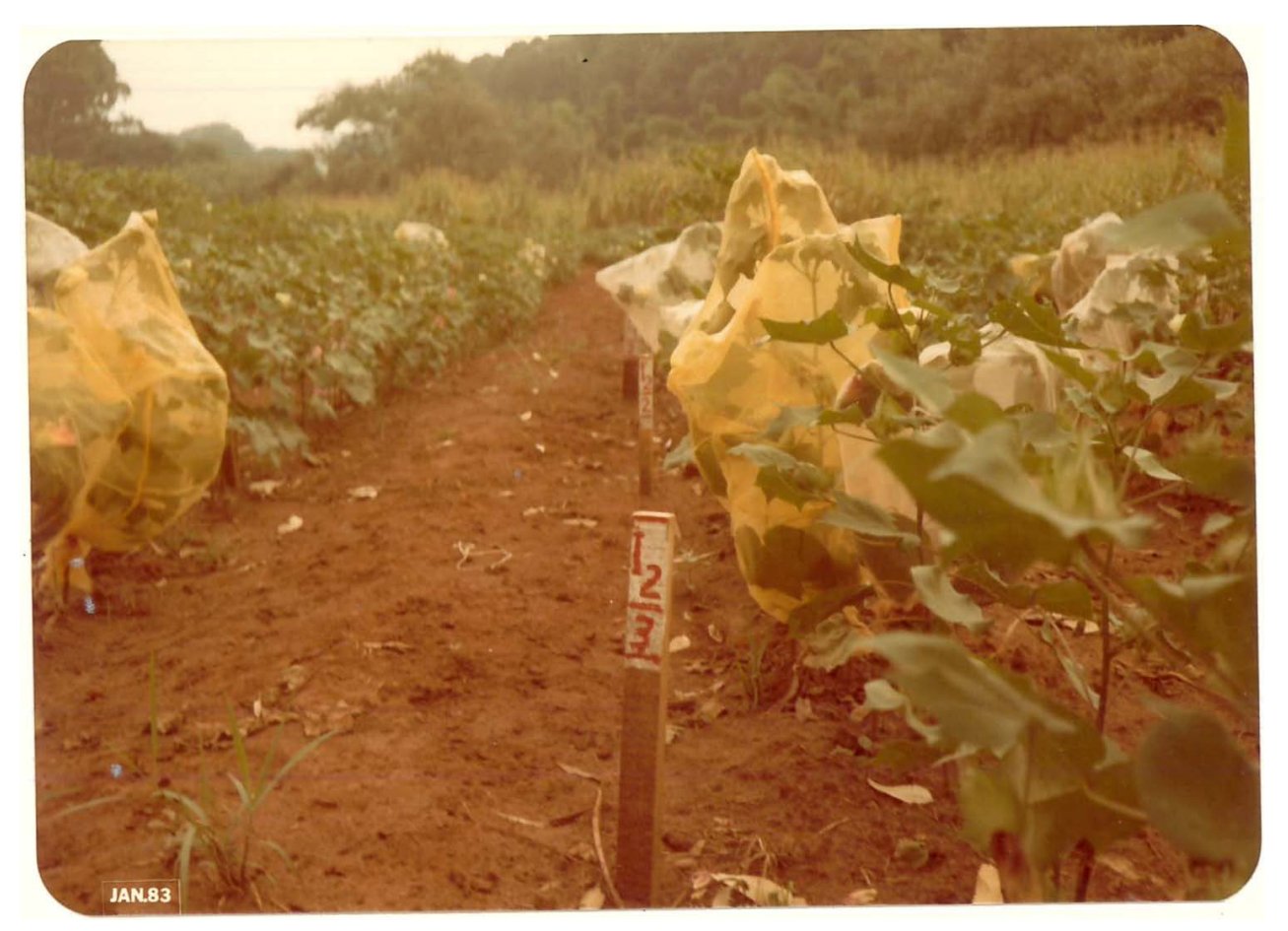

Figura 1 - Gaiolas utilizadas nas infestacões artificiais. com lagartas de $S$. frugiperda, em condicões de campo. 


\section{RESULTADOS E DISCUSS $\AA 0$}

4.1. Biologia comparada de $S$. frugiperda em folhas de aI godoeiro e milho, em condições de laboratório.

4.1.1. Fase de lagarta

4.1.1.1. Duração, viabilidade e peso

os dados referentes à duração e viabilidade

da fase larval em algodoeiro e milho encontram-se na Tabela 3 e nas figuras 2 e 3 . Pela Tabela 3 , pode-se constator que houve diferença estatística significativa, na duração desta fase, nos dois substratos alimentares. As lagartas criadas em folhas de algodoeiro, tiveram o periodo larval aumentado em 6,65 dias em relação àquelas criadas em milho. Embora a pesquisa tenha sido realizada em diferentes condições de tem peratura, umidade relativa e fotoperíodo, os dados obtidos em milho, para a duração do período larval, se aproximam da queles conseguidos por LUCCHINI (1977) e PATEL (1981), quan 
do criaram as lagartas em substrato natural (folhas de milho). Não foram encontradas na literatura referē cias a respeito da alimentação das lagartas de $S$. frugiperda em algodoeiro, portanto, a comparação do período larval, bem como de todas as outras fases do ciclo biológico dessa espé cie neste substrato, com resultados obtidos por outros auto res, tornou-se impraticāvel.

A viabilidade larval foi maior para as lagar tas criadas em folhas de milho. Acredita-se que a variação na viabilidade e duração larval, seja devido à preferência da praga por esta graminea, pois os insetos utilizados nos dois substratos, receberam as mesmas condições de temperatura, umi dade relativa, fotoperíodo e manipulação, considerando-se ain da, que o indice de ocorrēncia de doenças, foi praticamente nulo.

os pesos médios das lagartas no seu máximo desenvolvimento encontram-se na Tabela 3 e Figura 4. Verifi ca-se que não houve diferença estatistica entre os pesos ob tidos nas duas condições em estudo. Embora a viabilidade e a duração larval tenham sido afetadas pelo alimento fornecido, esse não afetou o peso das lagartas, indicando que provavel mente, a utilização do alimento foi semelhante nos dois subs tratos. 
Tabela 3 - Duração média, viabilidade e peso no máximo desen volvimento de lagartas de $S$. frugiperda criadas em folhas de algodoeiro da cultivar IAC-17 e fo lhas de milho híbrido HMD - 7974, à $25 \pm 2{ }^{\circ} \mathrm{C}$, UR: $60 \pm 10 \%$ e fotoperiodo: 14 horas.

\begin{tabular}{|c|c|c|c|c|c|c|c|}
\hline \multirow{2}{*}{$\begin{array}{l}\text { Parāmetros } \\
\text { biolōgicos }\end{array}$} & \multicolumn{2}{|c|}{ Algodoeiro } & \multirow{2}{*}{$V(\%)$} & \multicolumn{2}{|c|}{ Milho } & \multirow{2}{*}{$V(\%)$} & \multirow{2}{*}{$\begin{array}{c}\text { teste } \\
t\end{array}$} \\
\hline & i.v. & $\overline{\mathrm{m}}$ & & i.v. & $\bar{m}$ & & \\
\hline Duração & $17-29$ & $22,67 \pm 1,12$ & 80 & $14-18$ & $16,02+0,41$ & 86 & $12,02^{*}$ \\
\hline (dias) & & & & . & & & \\
\hline $\begin{array}{l}\text { Peso } \\
(\mathrm{g})\end{array}$ & $0,29-0,61$ & $0,47 \pm 0,02$ & - & $0,30-0,62$ & $0,44 \pm 0,03$ & - & 1,49 n.s \\
\hline
\end{tabular}

$i . v .=$ intervalo de variação; $\bar{m}=$ média; $V(\%)=$ viabilidade porcentual

* Significativo ao nível de $5 \%$ de probabilidade.

4.1.1.2. Nümero e duração dos instares 1 a vais.

A largura da cāpsula cefālica, o nūmero de îns tares, a duração de cada instar, com as respectivas razões de crescimento nos dois substratos estudados, acham-se nas Tabelas 4 e 5. A totalidade das lagartas criadas em folhas de algodoeiro apresentaram 7 instares, sendo que a partir do 30 instar observou-se um desenvolvimento mais lento, verifi cando-se, portanto, um alongamento na duração desses perío 
dos em relação às lagartas criadas em folhas de milho. Nesse substrato alimentar o nümero de instares encontrado foi 6 , na maioria dos casos, sendo que. $20 \%$ das lagartas atingiram o 70 instar, constatando-se ainda, neste caso, um encurtamen to da fase larval.

0 nūmero de instares encontrado para $S$. frugi perda, normalmente è variāvel de 5 (ESCALANTE, 1974 e PENAGOS, 1974) a 7 (LABRADOR, 1967 e LUCCHINI, 1977), sendo que a maioria se refere a 6 instares larvais (ESTRADA, 1960; RANDOLPH e WAGNER, 1966; LABRADOR, 1967 e PATEL, 1981). Estes resultados obtidos confirmam as afirmações feitas por WATERS (1937) e BAFIELD et alii (1978), de que a biologia de $S$. fru giperda pode ser alterada quando o inseto é alimentado com diferentes plantas hospedeiras e criado em diferentes regi mes de temperatura.

A razão de crescimento encontrada nos dois substratos estudados foi de 1,46 encontrando-se portanto no intervalo de variação estabelecido por DYAR (1890), o qual vai de 1,1 a 1,9 . 
Tabela 4 - Largura média da cápsula cefālica, razão de cres cimento e duração média, por instar, de 10 lagar tas de $S$. irugiperda criadas em folhas de algodo eiro da cultivar IAC- $17, \bar{a} 25 \pm 2^{\circ}$ C, U.R. $60 \pm$ 10\%, fotoperiodo: 14 horas.

\begin{tabular}{ccccc}
\hline Instar & \begin{tabular}{c} 
Largura da cāpsula cefālica \\
\cline { 2 - 5 }$(\mathrm{mm})$
\end{tabular} & $\bar{m}$ & $\begin{array}{l}\text { Razão de cres } \\
\text { cimento }\end{array}$ & $\begin{array}{c}\text { Duração } \\
\text { (dias) }\end{array}$ \\
\hline 10 & $0,32-0,33$ & 0,32 & 1,62 & $2,5 \pm 0,37$ \\
20 & $0,49-0,56$ & 0,52 & 1,35 & $2,0 \pm 0,47$ \\
30 & $0,64-0,76$ & 0,70 & 1,75 & $3,2 \pm 0,30$ \\
40 & $1,15-1,29$ & 1,22 & 1,47 & $4,2 \pm 0,81$ \\
50 & $1,71-1,90$ & 1,83 & 1,39 & $4,9 \pm 1,03$ \\
60 & $2,36-2,79$ & 2,52 & 1,16 & $4,2 \pm 0,81$ \\
70 & $2,81-3,04$ & 2,94 & & $3,1 \pm 0,53$
\end{tabular}

Média da razão de crescimento 1,46

i.v. = intervalo de variação; $\dot{\bar{m}}=$ média. 
Tabela 5 - Largura média da cāpsula cefálica, razão de cres cimento e duração mēdia, por instar, de 10 lagar tas de $S$. frugiperda criadas em folhas de milho híbrido HMD - 7974, à $25 \pm 2^{\circ} \mathrm{C}$, U.R.: $60 \pm 10 \%$, fo toperiodo: 14 horas.

\begin{tabular}{ccccc}
\hline Instar & $\begin{array}{c}\text { Largura da cápsula cefálica } \\
(\mathrm{mm})\end{array}$ & $\begin{array}{c}\text { Razão de Cres } \\
\text { i.v. }\end{array}$ & $\begin{array}{c}\text { Duração } \\
\text { (dias) }\end{array}$ \\
\hline 10 & $0,32-0,33$ & 0,32 & & $2,6 \pm 0,50$ \\
20 & $0,45-0,57$ & 0,51 & 1,59 & $2,4 \pm 0,37$ \\
30 & $0,69-0,85$ & 0,74 & 1,45 & $2,8 \pm 0,30$ \\
40 & $1,13-1,25$ & 1,20 & 1,62 & $2,8 \pm 0,45$ \\
50 & $1,75-2,03$ & 1,84 & 1,53 & $2,9 \pm 0,62$ \\
60 & $2,40-2,83$ & 2,62 & 1,42 & $3,7 \pm 0,48$ \\
70 & $2,94-3,04$ & 2,97 & 1,13 & $3,0 \pm 0,00 *$ \\
\hline Média da razão de crescimento & & 1,46 & \\
\hline
\end{tabular}

i.v. = intervalo de variação; $\bar{m}=m \vec{e} d i a$

* Apenas 20\% atingiram o 70 instar.

4.1.2. Fase de pré-pupa

Quando as lagartas, no ültimo instar, pararam 
de se alimentar, iniciou-se a fase de prē-pupa, que ē carac terizada pela redução do tamanho e diminuição do peso. A du ração e a viabilidade dessa fase, em função do alimento for necido, bem como as correspondentes comparações de médias, en contram-se na Tabela 6 e nas Figuras 2 e 3 . Observa-se que não houve diferença estatística significativa para a duração desta fase, nas condições em estudo.

As viabilidades pré-pupais encontradas foram de $96,50 \%$ e $98,90 \%$, respectivamente, para algodoeiro e milho, podendo-se notar que esta foi menor para os insetos que fo ram criados em folhas de algodoeiro.

Tabela 6 - Duração e viabilidade da fase de pré-pupa de $S$. Erugiperda criadas em folhas de algodoeiro da cul tivar IAC - 17 e folhas de milho híbrido HMD-7974, à $25+2^{\circ}$ C; U.R.: $60 \pm 10 \%$ e fotoperíodo: 14 ho ras.

\begin{tabular}{|c|c|c|c|c|}
\hline \multirow{2}{*}{ Substrato } & \multicolumn{2}{|c|}{ Duração (dias) } & \multirow{2}{*}{$\begin{array}{c}\text { Viabilidade } \\
\%\end{array}$} & \multirow{2}{*}{$\begin{array}{c}\text { teste } \\
t\end{array}$} \\
\hline & $i . v$. & $\bar{m}$ & & \\
\hline \multirow[t]{2}{*}{ Algodoeiro } & $1-3$ & $1,77 \pm 0,15$ & 96,50 & \\
\hline & & 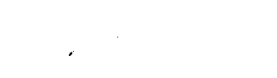 & & 1,49 n.s. \\
\hline Milho & $1-3$ & $1,58 \pm 0,17$ & 98,90 & \\
\hline
\end{tabular}

i.v. = intervalo de variação; $\bar{m}=$ média. 


\subsubsection{Fase de pupa}

A duração da fase pupal, bem como as compara ções de médias, para as duas condições alimentares, encon tram-se na Tabela 7 e Figura 2. Observa-se que houve uma me nor duração desta fase para as pupas que originaram fémeas, mas não apresentaram diferença estatística com relação aos substratos alimentares estudados. Os machos de $S$. frugiperda são mais sensíveis à alteração de alimento, observando-se um alongamento na duração pupal, quando as lagartas se desenvol veram em folhas de algodoeiro.

A viabilidade pupal foi mais elevada para os

insetos criados com folhas de milho, sendo possivel que o su bstrato alimentar, tenha influenciado esse comportamento (Ta bela 7 e Figura 3 ).

0 peso das pupas, originārias de lagartas cri adas com folhas de milho, tanto para machos como para fémeas, foi bem maior do que para aquelas criadas em folhas de algo doeiro. A diferença estatistica significativa constatada nes ta fase, vem comprovar mais uma vez a preferência das lagar tas de $S$. frugiperda pelo milho. (Tabela 7 e Figura 4). Os dados encontrados nas presentes condições experimentais, pa ra os insetos que se desenvolveram em folhas de milho, foram baixos em relação aos obtidos por KASTEN JR. et alii (1978) em dieta natural (folhas de milho). 
A razäo sexual calculada atravēs das pupas, pą ra as duas condições alimentares encontram-se na Tabela 7. os resultados obtidos indicam que a proporção de fêmeas para machos nos dois substratos estā ao redor de 1:1, podendo-se dizer que ambos os sexos foram afetados igualmente.

Tabela 7 - Duração, viabilidade, p̉so e razão sexual das pu pas de $S$. frugiperda criadas em folhas de algodo eiro da cultivar IAC-17 e folhas de milho híbrido HMD-7974 à $25 \pm 2^{\circ} \mathrm{C}$; UR: $60 \pm 10 \%$ e fotoperiodo: 14 horas.

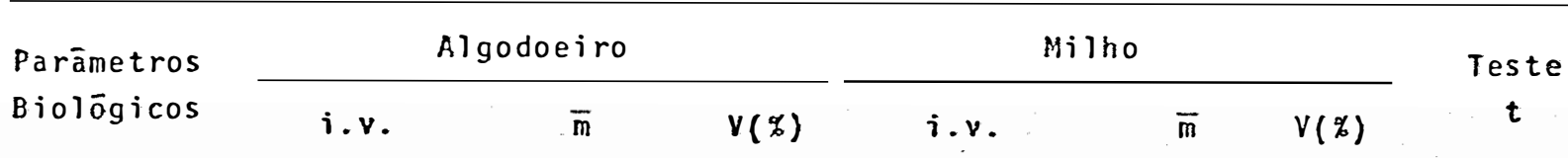

\begin{tabular}{|c|c|c|c|c|c|c|c|}
\hline Duraçāo & $86-9$ & $87,79 \pm 0,46$ & 82,50 & - 6-8 & $56,95 \pm 0,24$ & $90 ; 69$ & $83,73 \star$ \\
\hline (dia & $\overline{96-8}$ & $q 6,47 \pm 0,29$ & & $96-7$ & $q 6,32 \pm 0,23$ & & $\$ 0,86 n .5$ \\
\hline & $\sigma^{2} 0,13-0,22$ & $80,14 \pm 0,02$ & 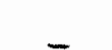 & $\sigma^{7} 0,73-0,22$ & $80,17 \pm 0,02$ & - & $\delta 2,94 *$ \\
\hline 1 & $q 0,10-0,22$ & $90,13 \pm 0,01$ & & $90,13-0,23$ & $q 0,16 \pm 0,01$ & & $93,47 \approx$ \\
\hline
\end{tabular}

Razão Sexual

0,57

0,47

$\mathbf{i} . \boldsymbol{v} .=$ intervalo de variação; $\bar{m}=$ média; $\mathbf{v}(\underset{\%}{o})=$ viabilidade percentual

* = Significativo ao nível de $5 \%$ de probabilidade. 
46.

4.1.4. Fase Adulta

4.1.4.1. Longevidade dos adultos e pe rîodo de prē-oviposição.

A longevidade dos adultos tanto de machos co mo de fêmeas tambēm foi maior para os insetos oriundos de fo Thas de milho, porēm, sem apresentar diferença estatística (Ta bela 8 e Figura 2). Os valores obtidos na presente pesquisa, para os insetos criados em folhas de milho,são discrepantes dos relatados por LUCCHINI (1977), que encontrou uma longe vidade de 21,1 dias para os machos e 12,4 dias para as fê meas, sendo os adultos provenientes de folhas de milho.

0 perīodo de pré-oviposição (Tabela 8), foi significativamente maior para os adultos oriundos de folhas de algodoeiro. Embora a presente pesquisa tenha sido realiza da em diferentes condições de temperatura, umidade relativa e fotoperiodo, os dados obtidos em milho, se aproximam daque les conseguidos por PATEL (1981).

4.1.4.2. Capacidade de Postura.

0 nümero de ovos colocados por fêmea, o nūme ro de ovos por postura e o nümero de postura por fêmea de S. frugiperda, e as suas respectivas comparações de médias, encontram-se na Tabela 8. 
Verifica-se que o alimento fornecido afetou a capacidade de postura, registrando-se por fêmea um nūmero de 649,71 ovos a mais, para adultos provenientes de lagartas cria das em folhas de milho. A fecundidade média diāria, diminuiu com a idade da fémea, observando-se, que o nūmero de ovos pos tos por fémea, foi decrescente a partir da primeira postura (Figura 5).

o nūmero de ovos por postura e o nūmero de pos turas por fémea diferiram estatísticamente, apresentando-se su perior para os insetos criados em folhas de milho.

0 nūmero total de ovos e de posturas por fê mea, na presente pesquisa, para os insetos criados em folha de milho (Figura 5 ), se encontram dentro da faixa observada pela maioria dos autores (LUGINBILL, 1928; LUCCHINI, 1977 e PATEL, 1981), quando criaram os insetos em folhas de milho.

As fêmeas provenientes de folhas de algodoeiro apresentaram, em média, um período de oviposição menor (4,92 dias) do que aquelas oriundas de folhas de milho (6,93 dias), sendo que, quase todas as fémeas morreram apōs a ūltima postú ra, registrando-se um perīodo mēdio de pós-oviposição de 1,59 e 2,00 dias, respectivamente, para $S$. frugiperda proveniente de algodoeiro e milho. 


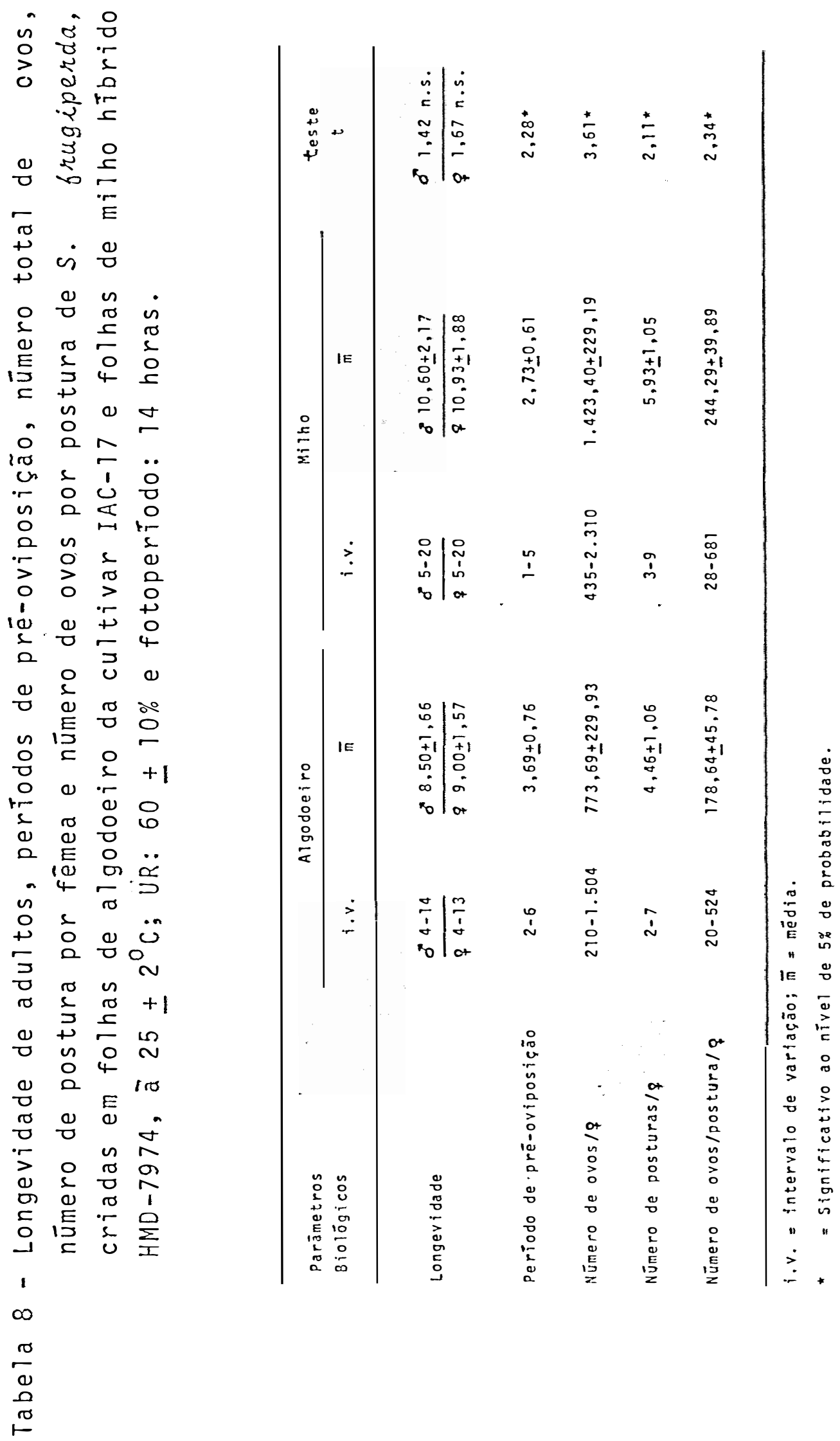




\subsubsection{Fase de ovo}

os períodos médios de incubação de $S$. frugiper da encontram-se na Tabela 9 e Figura 2, podendo-se observar que a duração desse período foi idêntica para os dois hospe deiros em estudo, 0 fato do período de incubação não ter va riado nos dois substratos analisados, está de acordo com os resultados apresentados por LUGINBILL (1928), ETCHEVERRY (1957), LABRADOR (1967) e PATEL (1981), que afirmaram ser es te período, influenciado basicamente pelas condições de tempe ratura, acima de qualquer outra variável.

A viabilidade dos ovos foi de 69,79 e $80,11 \%$, respectivamente, para algodoeiro e milho (Figura 3 ), poden do-se notar que esta foi menor para os insetos criados em folhas de algodoeiro. Foi observado que essa viabilidade de um modo geral,foi decrescente a partir da primeira postura (Figura 5). O valor encontrado para viabilidade do ovo, nas presentes condições experimentais, quando os insetos foram obtidos de folhas de milho, foi um pouco menor do que os re gistrados por LUCCHINI (1977) e KASTEN JR. et alii (1978), provavelmente devido à problemas durante a manipulação dos ovos. 


\subsubsection{Ciclo Total e Considerações Gerais}

o ciclo biológico médio (ovo até a morte do adulto) de $S$. frugiperda foi de 43,36 e 38,14 dias, respecti vamente, em algodoeiro e milho (Tabela 9). Portanto, o ciclo de vida foi afetado pelo alimento, principalmente na fase de lagarta, que é a fase mais importante do ciclo biológico da espécie em estudo, por causar danos às culturas.

Todos os parâmetros analisados, foram mais fa vorāveis aos insetos criados em folhas de milho. Provavelmen te este fato ocorreu devido a uma maior adaptabilidade dapra ga à esta cultura. Embora existam citações da espécie em es tudo atacando folhas de algodoeiro, esse ataque é mais acen tuado, nos primeiros instares, pois a maioria das lagartas não completam o seu desenvolvimento nesta parte da planta, tendo preferéncia pelas estruturas frutiferas do algodoeiro. Desta forma è provāvel que,estas estruturas contenham algu ma substância nutritiva que favoreça o desenvolvimento dos insetos. O presente trabalho foi desenvolvido em folhas de algodoeiro, devido a impossibilidade técnica de estudos em maçãs, pela contaminação que normalmente ocorre. 
Tabela 9 - Duração média das fases de lagarta, pré-pupa, pú pa, adulto e períodos de incubação de ovos de $S$. frugiperda, obtida de folhas de algodoeiro da culti var IAC-17 e folhas de milho hibrido HMD-7974, à $25 \pm 2^{0} \mathrm{C}$, UR: $60 \pm 10 \%$ e fotoperiodo: 14 horas.

Fases do ciclo

(di as)

Algodoeiro Milho

\begin{tabular}{|c|c|c|}
\hline Lagarta & $22,67 \pm 1,12$ & $16,02 \pm 0,41$ \\
\hline Prē-pupa & $1,77 \pm 0,15$ & $1,58 \pm 0,17$ \\
\hline \multirow[t]{2}{*}{ Pupa } & $\sigma^{\pi} 7,79 \pm 0,46$ & $86,95 \pm 0,24$ \\
\hline & $96,47 \pm 0,29$ & $96,32 \pm 0,23$ \\
\hline \multirow[t]{2}{*}{ Adul to } & $88,50 \pm 1,66$ & $310,60 \pm 2,17$ \\
\hline & $99,00 \pm 1,57$ & $q 10,93 \pm 1,88$ \\
\hline \multicolumn{3}{|l|}{ Ovo (Períodos de incu } \\
\hline Ciclo total * & 43,36 & 38,14 \\
\hline
\end{tabular}

* Valores médios (ovo até a morte do adulto). 
52.

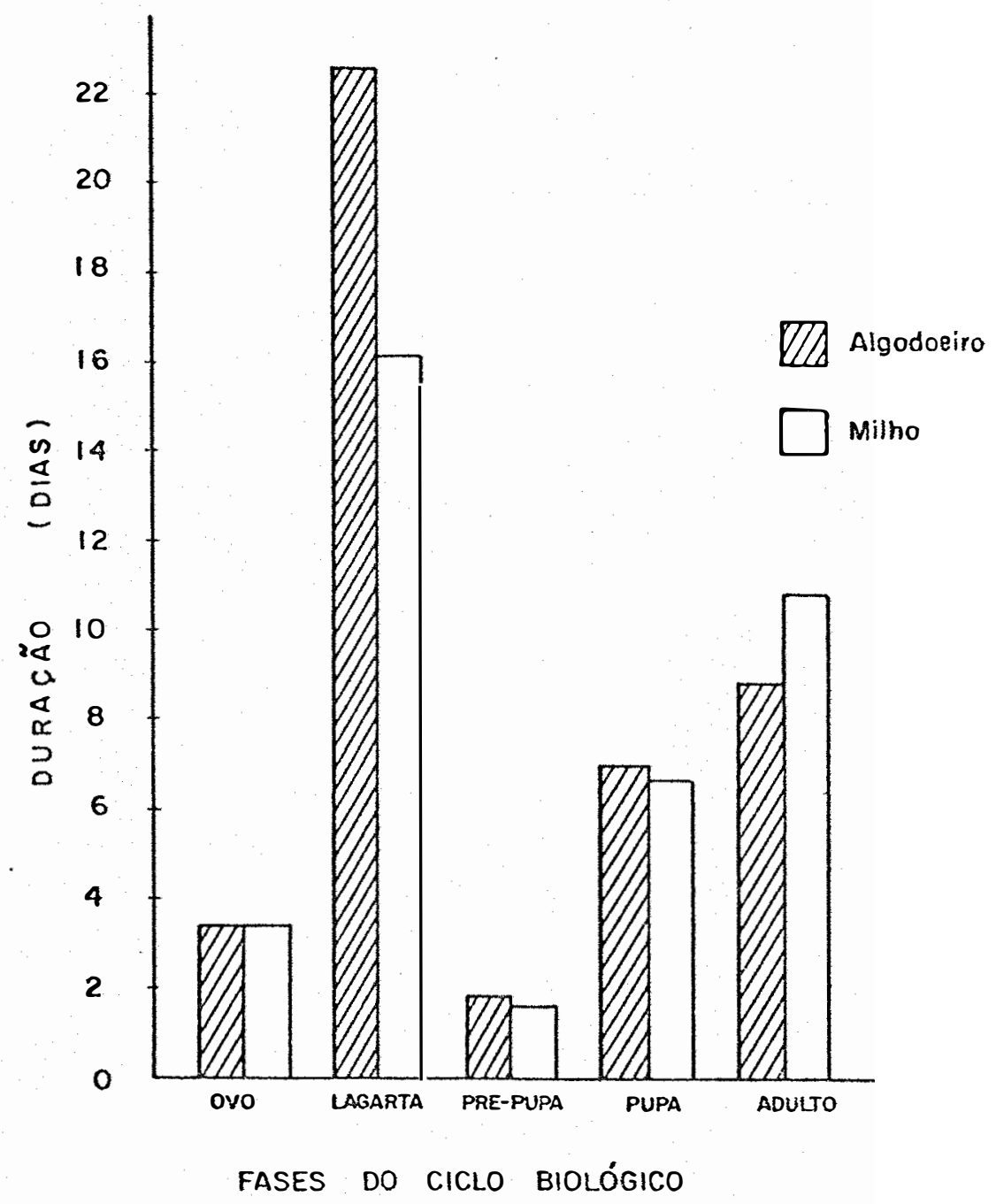

Figura 2 - Duração média das fases de ovo, 1 agarta, prē-pupa, pupa e adulto de $S$. frugiperda, criadas em algo doeiro da cúltivar IAC-7.7 e milho híbrido HMD-7974, à $25 \pm 2^{0} \mathrm{C} ;$ UR; $60 \pm 10 \%$ e fotoperiodo: 14 horas. 


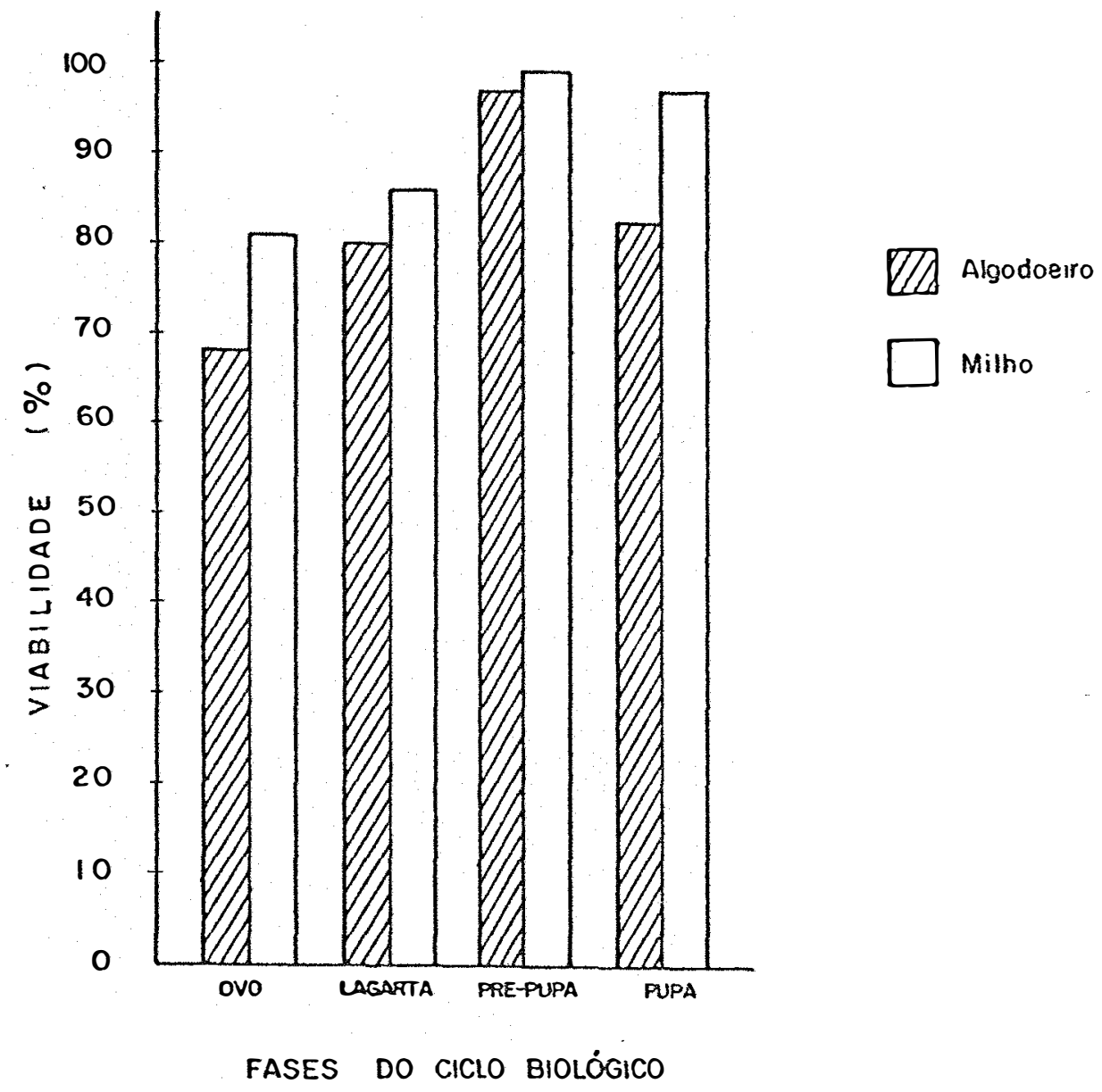

Figura 3 - Viabilidade das fases de ovo, lagarta, pre-pupa e pupa de $S$. frugiperda, criàdas em algodoeiro dacuI tivar IAC - 17. e milho híbrido HMD - 7974, à $25+$ $2^{0}$ C; U.R.: $60 \pm 10 \%$ e fotoperiodo: 14 horas. 
54.

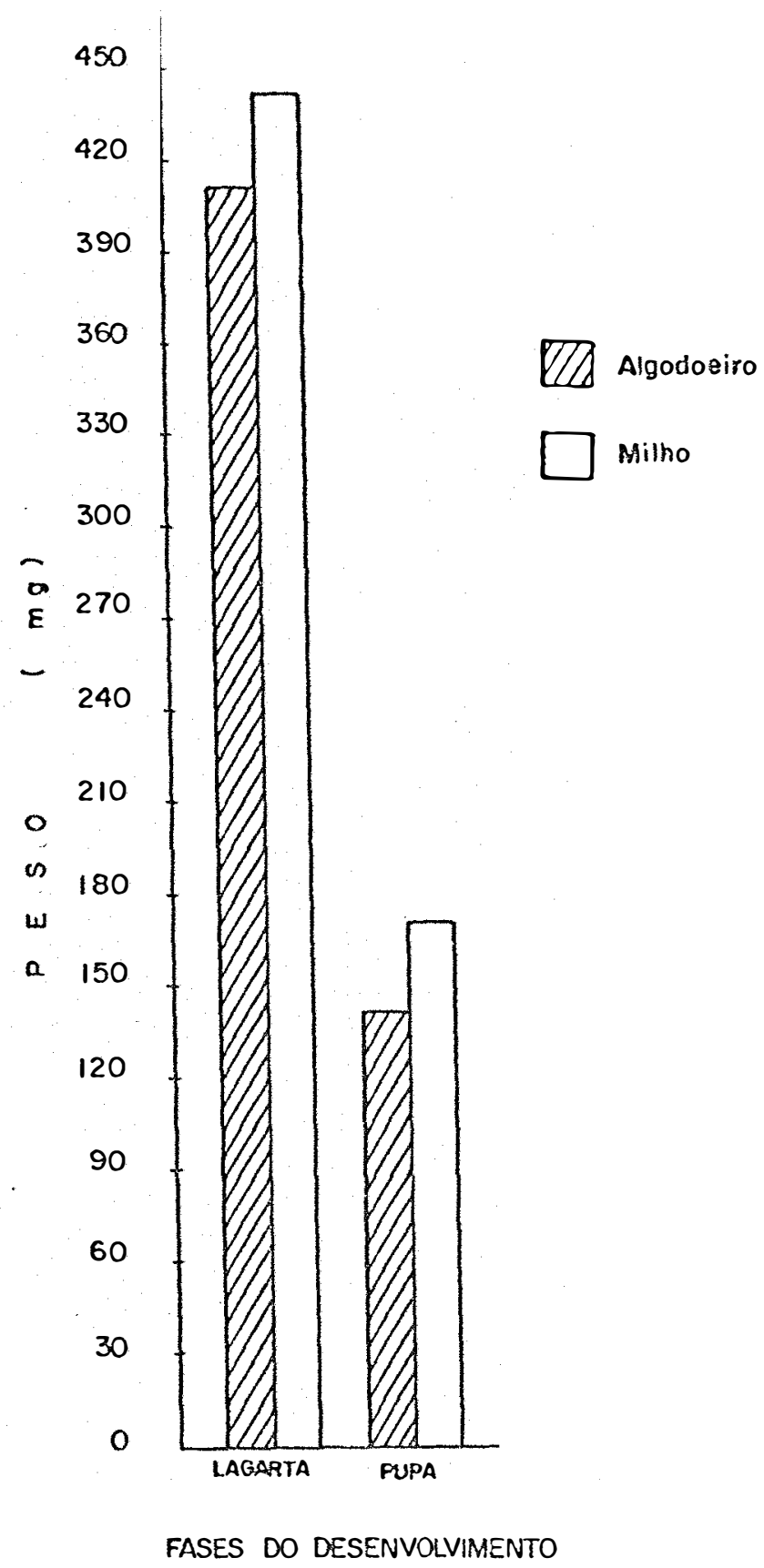

Figura 4 - Peso das lagartas no máximo desenvolvimento e pe so médio de pupas de $S$. frugiperda,criadas em al godoeiro da cútivär IAC-T7 e milho híbrido HMD$7974, \bar{a} 25 \pm 2^{0}$ C; U.R.; $60 \pm 10 \%$ e fotoperiodo: 14 horas. 
55.

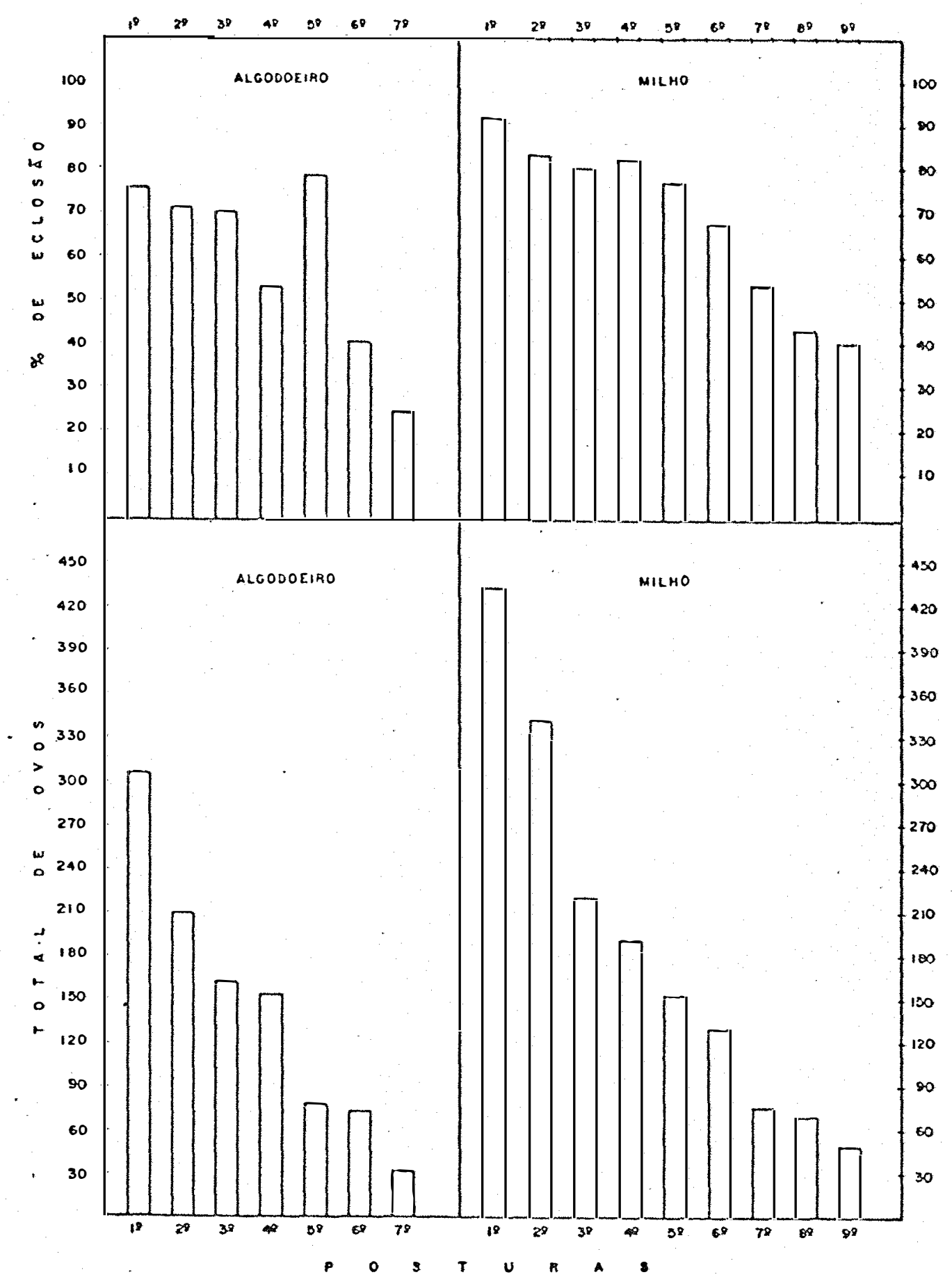

Figura 5 - Posturas e viabilidadesdiārias de $S$. frugiperda, criadas em algodoeiro da cultivar IAC-17 e milho hîbrido HMD-7974, à $25 \pm 2^{0} \mathrm{C}, U . R .: 60 \pm 10 \%$ e fo toperíodo: 14 horas. 


\subsection{Danos de $S$. frugiperda em algodoeiro}

Foram observados em condições de campo os hā bitos das lagartas de $S$. Crugiperda em plantas de algodoei ro,em duas safras agrícolas consecutivas.

As lagartas dessa espécie alimentam-se de fo folhas, botões florais e sobretudo de maçãs. Nos primeiros es tágios de desenvolvimento, apresentam uma certa preferéncia pelas brácteas dos botões florais para posteriormente passa rem às maçãs. Os danos provocados são lesões que geralmente se localizam na parte inferior da maçã prōximo ao pedūnculo, sendo que podem tambēm, lesionar grande parte da ārea superí or da maçã. Em estágios de desenvolvimento mais adiantadosas lagartas penetram principalmente na base das maçãs fazendo orifícios grandes e irregulares, deixando sempre nas bräcte as uma grande quantidade de excrementos (Figura 6).

Conhecendo-se o comportamento da espécie fo. ram conduzidos os experimentos que se seguem:

4.2.1. Determinação dos efeitos dos diferentes ni. veis de infestação da lagarta de $S$. frugiper da na produção do alģodoeiro.

os valores médios dos dados de produção de al godão em caroço obtido nas diferentes parcelas infestadas aos 75 e 95 dias da germinação das plantas, estão registra 
57.

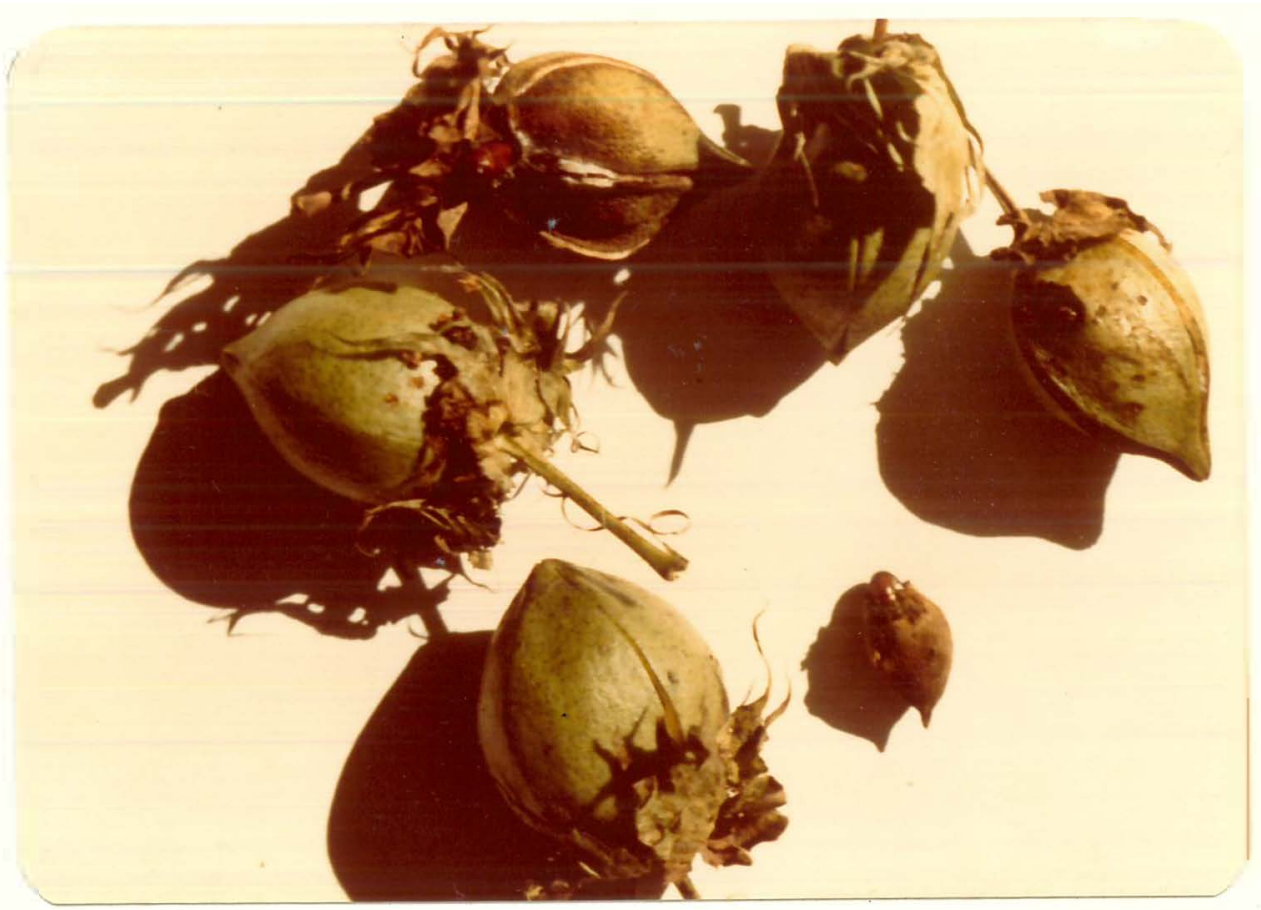

Figura 6 - Danos de $S$. frugiperda em maçãs de algodoeiro.

dos na Tabela 10. Os quadrados mëdios (pelo esquema fatorial $4 \times 2$ ) da produção de algodão em caroço, envolvendo nümero de in seto e época de infestação, encontram-se na Tabela 11. Pode-se observar que não houve interação entre épocas e níveis de in festação; no entanto, quando analisados isoladamente, o nūme ro de insetos em cada tratamento (75 e 95 dias) foi estatisti camente diferente pelo teste $F$ ao nível de $1 \%$ de probabilida de.

Os quadrados médios para os dados de produção de algodão em caroço, encontram-se na Tabela 12. Observa-se que aos 75 dias houve uma relação quadrática entre os níveis 
de infestação e a produção, sendo que, aos 95 dias ocorreu a penas uma relação linear entre estas variáveis.

As èuações de regressão, não sō para anālise de produção, assim como, para todos os outros parámetros, fo ram determinadas através da média dos tratamentos. Aquelas que melhor se ajustaram à produção de algodão, com infestação aos 75 e 95 dias da germinação das plantas, foram, respectivamente.

$$
\begin{aligned}
& \hat{Y}=107,4218-22,6709 x+3,5909 x^{2} \\
& \widehat{Y}=92,2000-7,7143 x
\end{aligned}
$$

As representações grāficas dessas equações encontram-se nas figuras 7 e 9 .

Na Figura 7 (produção com infestação aos 75 dias), verifica-se que à medida que aumentou o número de lagar tas por planta, ocorreu uma maior queda na producão. Porém observou-se um decréscimo bem mais acentuado entre a testemunha e a inféstação com uma lagarta $(22,59 \%)$, enquanto que, para as infestações com 2 e 4 lagartas esse decréscimo não obedece à mesma proporcão, ou seja, foram de $26,05 \%$ e $33,15 \%$, respectiva mente. Assim, a redução de produção provocada por uma lagarta foi bastante próxima aos decréscimos de producão induzidos por 2 e 4 lagartas. Este comportamento talvez possa ser explicado pelo fato das lagartas de $S$. frugiperda possuirem canibalisticos. O canibalismo da espécie em questão, foi confirmado por HYNES (1942), LEIDERMAN e SAUER (1953), ETCHEVERRY (1957) e CARVALHO (1970), em cultura do milho. 
0 período de seca ocorrido nos meses em que - algodoeiro estava em pleno desenvolvimento vegetativo, pre judicou o florescimento das plantas atrasando o início da frutificação; portanto, na infestação aos 75 dias da germina ção existiam poucos ōrgãos frutîferos nas plantas de algodo eiro. Assim, considerando a espécie em estudo como apenas pra ga de estruturas frutíferas, os danos na produção não seriam significativos pelo fato de que nesta época poucos ōrgãos fru tîferos estavam presentes nas plantas. De acordo com COVARR BIAS e PACHECO (1970) e SANTOS e MARUR (1980), os danos nas estruturas de frutificação do algodoeiro aos 75 dias da ger minação não causam diferença em termos de produção; pois quan to mais cedo ocorrer o dano, maior a possibilidade de recupera ção por parte da planta.

Entretanto, levando-se em consideração que es ta espēcie não é apenas prága de estruturas frutíferas, os e feitos dos danos na produção de algodão verificado nessa pes quisa, para esse período, foi provavelmente devido a um ata que severo das lagartas aos ponteiros e aos caules, com corte parcial ou total (Figura 8). HERRERA (1961) encontrou este mes mo tipo de dano, em plantas de algodoeiro bem desenvolvidas.

Na Figura 9, observa-se que aos 95 dias da germinação das plantas, a produção diminui linearmente com os níveis de infestação. A explicação mais provāvel para e te comportamento, talvez seja porque nessa época, as plantas 


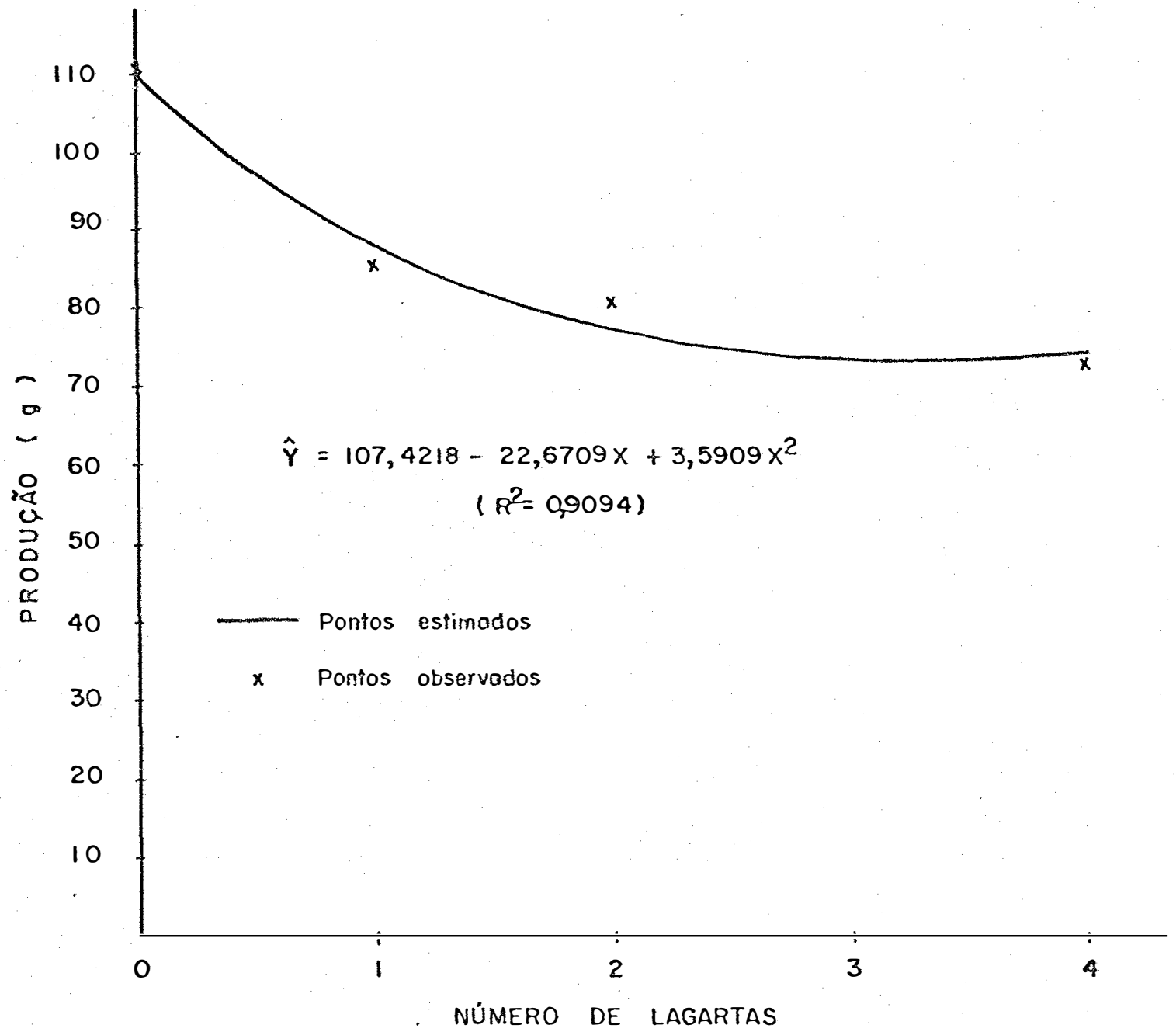

Figura 7 - Relação entre o número de lagartas e a produção das plantas de algodoeiro infestadas aos 75 dias da ger minação.

de algodoeiro apresentavam-se com maior nümero de örgãos de frutificação. Foi observado que a maioria das lagartas quando colocadas nas plantas, se direcionaram a estes órgãos, mostran do a sua preferéncia por estas estruturas. E interessante rela 
61.

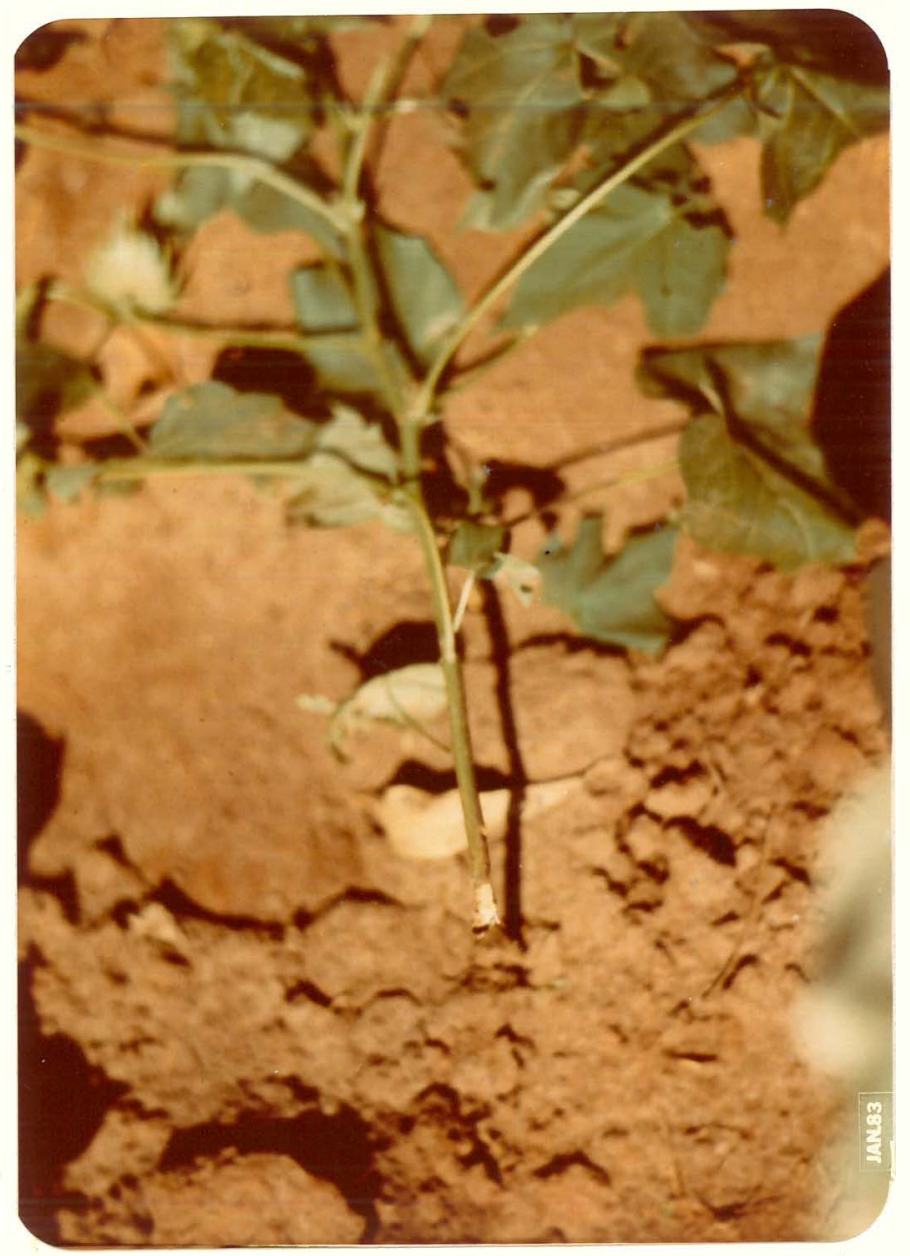

Figura 8 - Dano de $S$. frugiperda em caule de algodoeiro.

tar ainda que, não foi encontrada mais de uma lagarta no $\bar{u}$ t $\underline{i}$ mo înstar, por maçã. E possĩvel que estas condições tenhani fa vorecido uma diminuição do canibalismo, como pode ser observado atravēs dos valores médios do nümero de pupas encontradas nas 


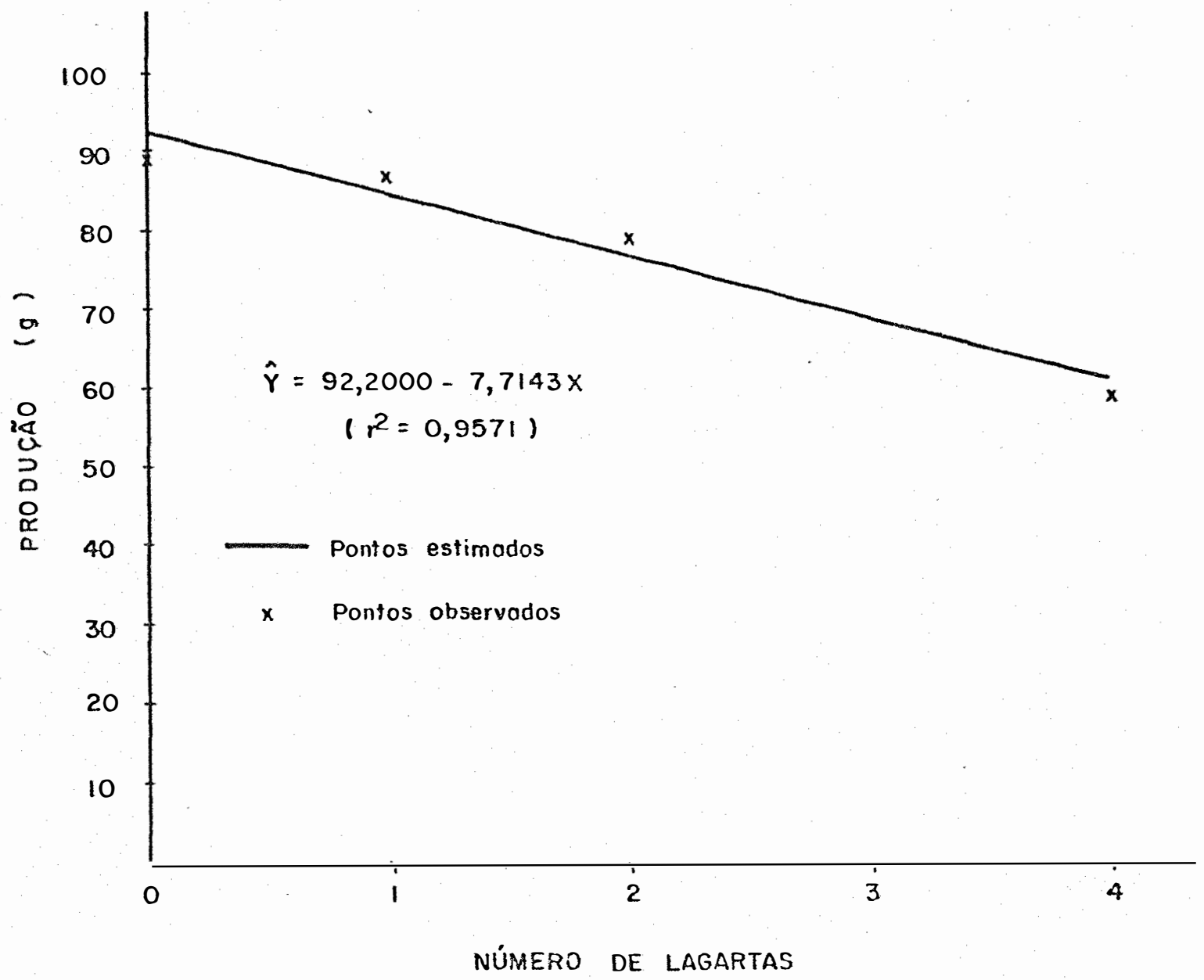

Figura 9 - Relação entre o número de lagartas e a produção das plantas de algodoeiro infestadas aos 95 dias da ger minação .

duas épocas de infestação (Tabela 10).

As diferenças de produção aos 95 dias da ger minação das plantas entre a testemunha e os níveis de infesta ção com 1,2 e 4 lagartas por planta, foram, respectivamente: $2,47,11,43$ e $33,18 \%$.

SANTOS E MARUR (1980), simularam os danos oca sionados pelas pragas destruidoras de estruturas frutîferas 
nos níveis de 33,66 e $100 \%$ e concluiram que no plantio dentro da época recomendada a redução na produção ocorreu a partir dos 85 dias da germinação das plantas, para os trēs níveis de simulação considerados. Portanto, os dados obtidos para a in festação aos 95 dias, concordam com os resultados apresentados pelos autores.

Observa-se que não houve direfença estatistị ca significativa entre as épocas de infestação (Tabela 11), no entanto, era de se esperar que um ataque direto das lagartas aos ōrgãos de produção, aliados a um menor canibalismo como ocorreu aos 95 dias, viesse a provocar um maior decréscimo de produção. Provavelmente, se a infestação artificial tivesse sido realizada em ëpocas de maior concentração de maçãs $(100$ e 110 dias da germinação das plantas, segundo SANTOS; 1977), os danos sobre a prơdução serïam significativamente diferentes dos apresentados nas duas épocas estudadas.

Na Tabela 10, encontram-se os valores médios referentes ao nümero de ponteiros cortados para a infestaçăo aos 75 dias da germinação das plantas. Os quadrados médios pa ra o numero de ponteiros cortados foram apresentados na Tabela 12. Aos 75 dias encontrou-se uma relação linear entre os ní veis de infestação e o número de ponteiros cortados.

A equação de regressão que melhor se ajustou para o nümero de ponteiros cortados aos 75 dias, foi:

$$
P=0,2400+1,1771 x
$$




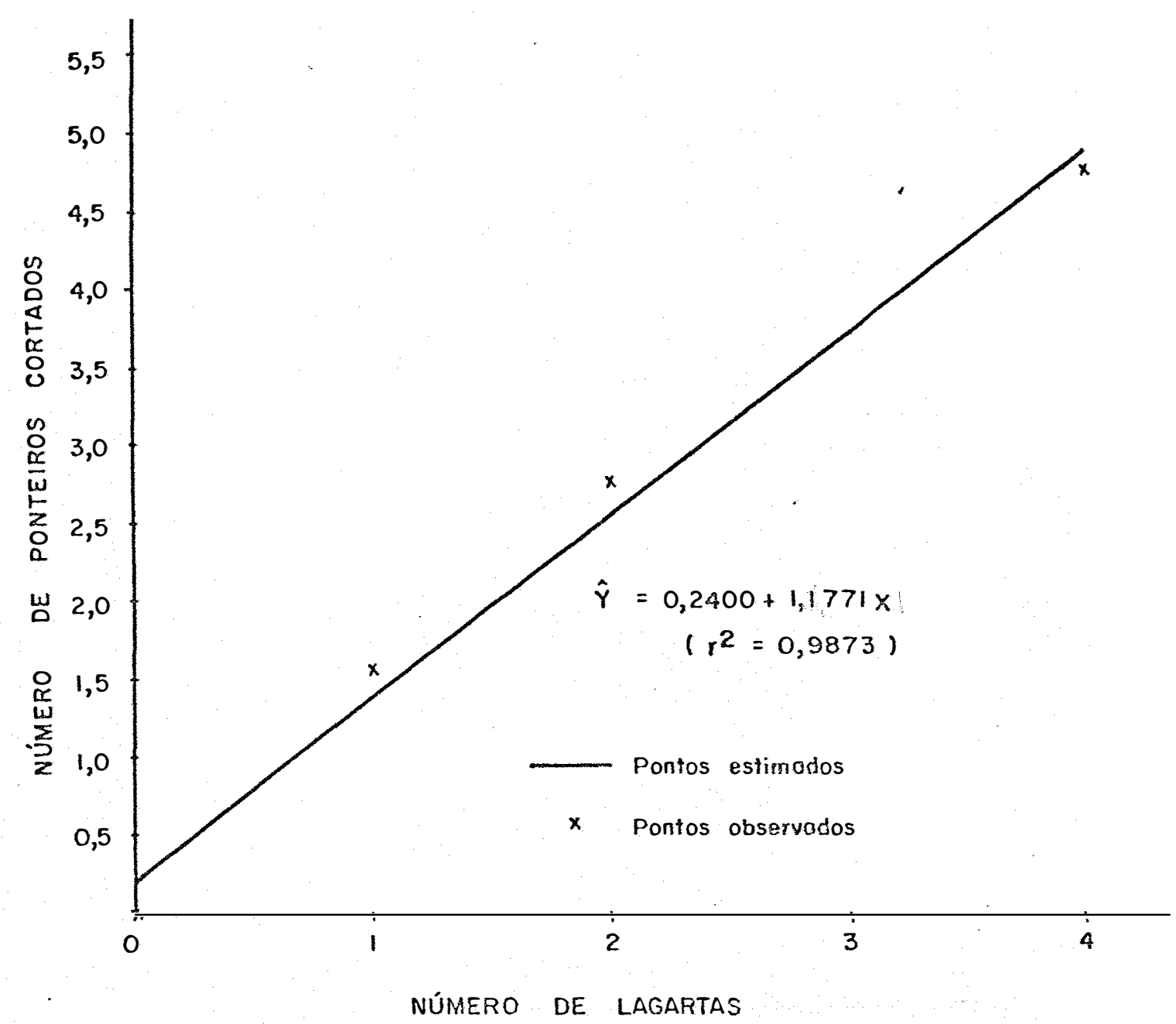

Figura 10 - Relação entre o nümero de lagartas e o nūmero de ponteiros em plantas de algodoeiro infestadas aos 75 dias da germinação.

A representação grāfica dessa equação encon tra-se na Figura 10. Observa-se neste gräfico, que a intensi dade dos danos nos ponteiros foi maior à medida que aumentou o nūmero de lagartas por planta. Este comportamento apresenta 
do pelas lagartas de $S$. frugiperda, jā tinha sido relatado por outros autores, tais como, LUGINBILL (1950), FENTON (1952) e HOWEEL JR. (1978).

A espécie em estudo se comportou de maneira diferente com relação ao corte dos ponteiros das plantas, nas duas épocas de infestação, sendo que aos 75 dias as lagartas causaram sérios danos, porêm, aos 95 dias não foi verificado dano algum nos ponteiros das plantas. A explicação para este comportamento talvez seja devido à preferéncia da lagarta pe las estruturas de frutificação, pois aos 95 dias as plantas de algodoeiro apresentavam-se com maior número dessas estrutu ras, como foi relatado anteriormente na discussão da Figura 9.

os valores médios dos dados para o nüme ro de pupas encontradas nos diferentes nīveis de infesta ção, para as duas épocas de desenvolvimento das plantas de al godoeiro, encontram-se na Tabela 10. Os quadrados médios (pe10 esquema fatorial $4 \times 2$ ) para o nümero de pupas encontradas, envolvendo nümero de inseto e época de infestação, acham-se na Tabela 11. Verifica-se que a interação nümero de inseto e ēpo ca de infestação, mostrou-se significativa com relação ao nūme ro de pupas encontradas.

os quadrados mêdios do nūmero de pupas encon tradas nas duas ēpocas de infestação, encontram-se na Tabela 12. Observa-se que para as duas ēpocas, houve uma relação quadrática entre os nĩveis de infestação e o nūmero de pupas. 
As equações de regressão que melhor se ajustaram para o número de pupas encontradas com infestação aos 75 e 95 dias da germinação das plantas, foram, respectivamente:

$$
\begin{aligned}
& P=0,0327+4,5436 x-0,4636 x^{2} \\
& P=7,0 x-0,6 x^{2}
\end{aligned}
$$

Suas representações grāficas encontram-se nas

Figuras 11 e 12 .

Observando-se estas figuras, verifica-se que o nūmero de pupas encontradas nas duas ēpocas de infestação au mentou com o número de lagartas, porēm,aos 95 dias, obteve-se uma maior quantidade de pupas para os diferentes niveis de in festação. A explicação mais provável para este comportamento, jā foi relatada anteriormente na discussão da Figura 9. 
67 .

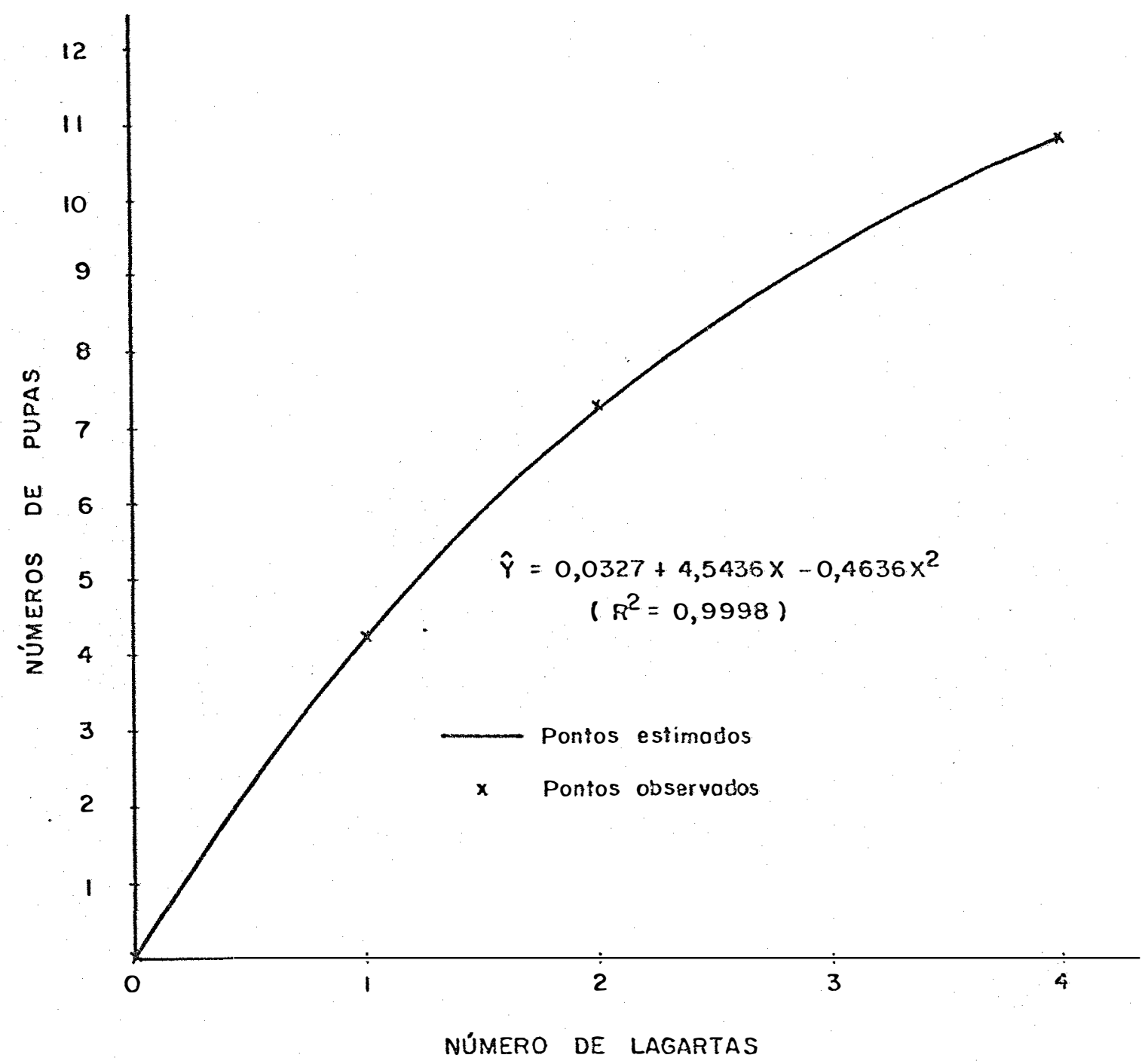

Figura 11 - Relação entre o nūmero de lagartas e o nūmero de pupas encontradas na infestação aos 75 dias da germinação das plantas de algodoeiro. 


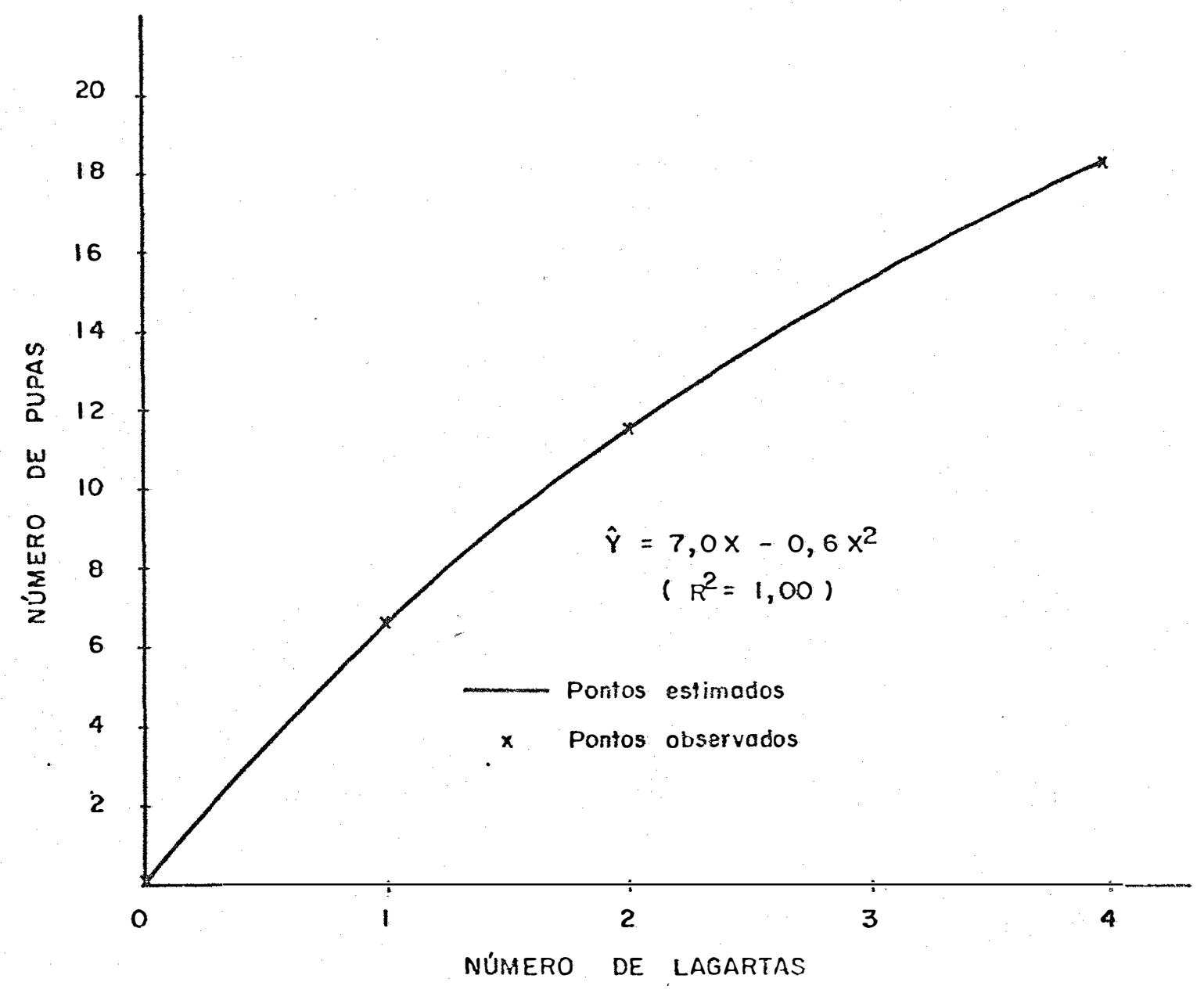

Figura 12 - Relação entre o número de lagartas e o nūmero de pupas encontradas na infestação aos 95 dias da germinação das plantas de algodoeiro. 
Tabela 10 - Valores médios de produção de algodão em caroço, nūmero de ponteiros cortados e nūmero de pupas encontradas, nas diferentes parcelas das plantas infestadas aos 75 e aos 95 dias da germinação, com lagartas de $S$. frugiperda. Piracicaba, SP.: 1981.

\begin{tabular}{|c|c|c|c|c|c|c|}
\hline \multirow{3}{*}{ Tratamentos } & \multicolumn{2}{|c|}{ Produção (g) } & \multicolumn{2}{|c|}{$\begin{array}{l}\text { No de ponteiros } \\
\text { cortados }\end{array}$} & \multicolumn{2}{|c|}{$\begin{array}{l}\text { NO de pupas } \\
\text { encontradas }\end{array}$} \\
\hline & Epocas & (dias) & Epocas & (dias) & Epocas & (dias) \\
\hline & 75 & 95 & 75 & 95 & 75 & 95 \\
\hline 1 & 85 & 87 & 1,6 & - & 4,2 & 6,4 \\
\hline 2 & 81,2 & 79 & 2,8 & - & 7,2 & 11,6 \\
\hline 4 & 73,4 & 59,6 & 4,8 & - & 10,8 & 18,4 \\
\hline Tes temunha & 109,8 & 89,2 & 0 & - & 0 & 0 \\
\hline
\end{tabular}


Tabela 11 - Quadrados médios (pelo esquema fatorial $4 \times 2$ ) da produção de algodão em caroço e do nūmero de pú pas encontradas, envolvendo nūmero de insetos e época de infestação (Dados transformados em $\sqrt{x+0,5}$

\begin{tabular}{lccc}
\hline Causas de Variação & G.L. & Produção & $\begin{array}{c}\text { Número de pupas } \\
\text { encontradas }\end{array}$ \\
\hline Blocos & 4 & $1.389,15^{* *}$ & 0,03 \\
Tratamentos & $(7)$ & $1.022,61 * *$ & $8,35 * *$ \\
$\quad$ Nọ de Insetos (N.I.) & 3 & $1.848,90^{* *}$ & $18,05 * *$ \\
$\quad$ Epoca (E) & 1 & 624,10 & $2,93^{* *}$ \\
$\quad$ Interação (N.I.X E.) & 3 & 329,17 & $0,44 * *$ \\
Resîduo médio & 28 & 240,79 & 0,04 \\
Coeficiente de Varia & & & 2,73 \\
ção (\%) & - & & \\
\end{tabular}

** Significativo ao nível de $1 \%$ de probabilidade. 


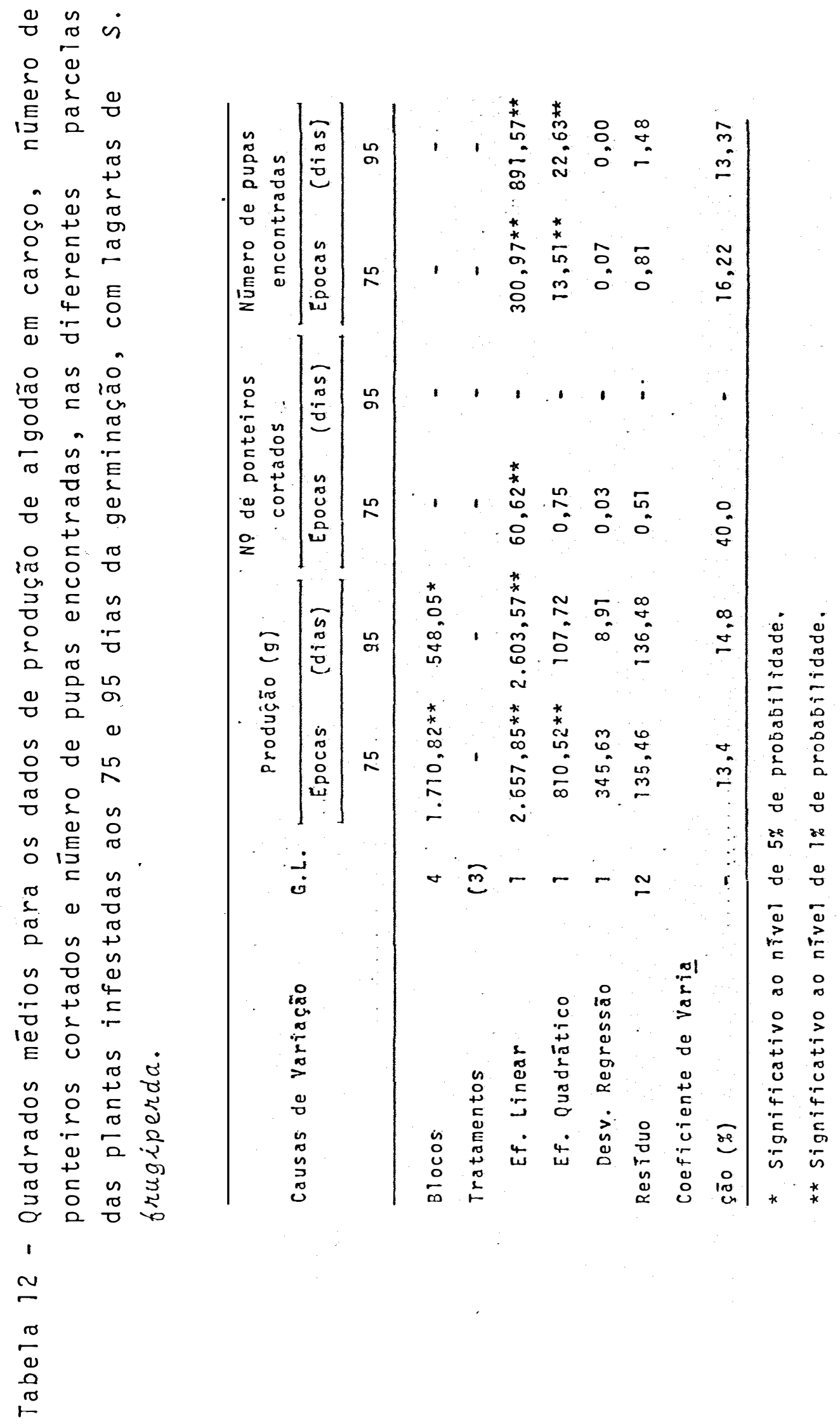


4.2.2. Estruturas frutíferas do algodoeiro danifica das por lagartas de $S$. Grugiperda em diferen tes épocas de desenvolvimento da cultura.
4.2.2.1. Estado fenológico das plantas de al godoeiro

Os valores médios do estado fenológico das plantas na época que foram realizadas as infestações artifi ciais, encontram-se na Tabela 13 , e estes mesmos valores ex pressos em porcentagem acham-se na Figura 13. 0 periodo mais intenso de formação de botões florais foi aos 85 dias em 64,97\%. No entanto, para 100 e 115 dias houve predominância de maçãs em $55,83 \%$ e $76,69 \%$, respectivamente. As flores apre sentaram uma porcentagem bastante baixa, aos $85(6,19 \%)$ e 100 dias $(6,67 \%)$ e principalmente aos 115 dias $(0,33 \%)$. Estas por centagens estão de acordo com os resultados obtidos por Co VARRUBIAS e PACHECO (1970), SANTOS (1977) e BERTOLOTI (1978).
4.2.2. Número de estruturas frutîferas danif $\underline{i}$ cadas por planta, com lagartas de $S$. frugiperda.

Na Tabela 14, encontram-se os quadrados mé dios dos nūmeros de botões florais, maçãs e totais de estru turas frutiferas (botões florais, flores e maçãs) danifica das por planta, com 1 e 2 lagartas de $S$. Grugipenda. Dentre 
todas as variáveis estudadas, apenas o nūmero de inseto afe tou as maçãs e o total de estruturas frutíferas, significa tivamente pelo teste $F$ ao nivel de $1 \%$ de probabilidade.

0 nūmero de flores danificadas não foi anali sado isoladamente, devido ao fato de não terem sido encontrado variações entre os danos, nas trēs épocas de infestação.

As porcentagens de estruturas frutiferas dani ficadas acham-se na Tabela 15 e Figura 14. Observa-se de mo do geral, que as lagartas desta espēcie provocaram uma redu ção acima de 10\% (exceto para flores aos 115 dias) no nūmero de estruturas frutiferas por planta. Mesmo com 2 lagartas por planta não se observou em média nas diferentes ēpocas, danós acima de $30 \%$ pará maçãs $(26,20 \%)$ e totais de estrutu ras frutíferas $(22,49 \%)$.

Os dados relativos ao nūmero médio de estru turas frutíferas danificadas, sem levar em consideração o nū mero de estruturas frutíferas existentes nas plantas, nas épo cas de infestações, encontram-se na Tabela 16. Verifica - se que 1 lagarta danificou aos 85,100 e 115 dias, respectiva mente $3,8,4,4$ e 3,0 estruturas frutiferas, enquanto que 2 lagartas danificaram $6,0,5,2$ e 3,4 .

SANTOS (1977), infestando as plantas com la gartas de Heliothis virescens (Fabr. 1781), no período de florescimento do algodoeiro, encontrou que, 1 lagarta des trói durante seu desenvolvimento 6,68 estruturas frutíferas. Porém, no presente experimento 1 lagarta de $S$. Grugíperda da 
nificou apenas 3,73 estruturas frutiferas. Pode-se dizer em termos numēricos, que a lagarta de $H$. virescens destrōi prat $\underline{i}$ camente o dobro de estruturas frutiferas, quando comparada com os danos provocados pela lagarta de $S$. frugiperda, mas, deve-se levar em consideração, que a pesquisa realizada, foi conduzida em diferentes condiçöes experimentais. 


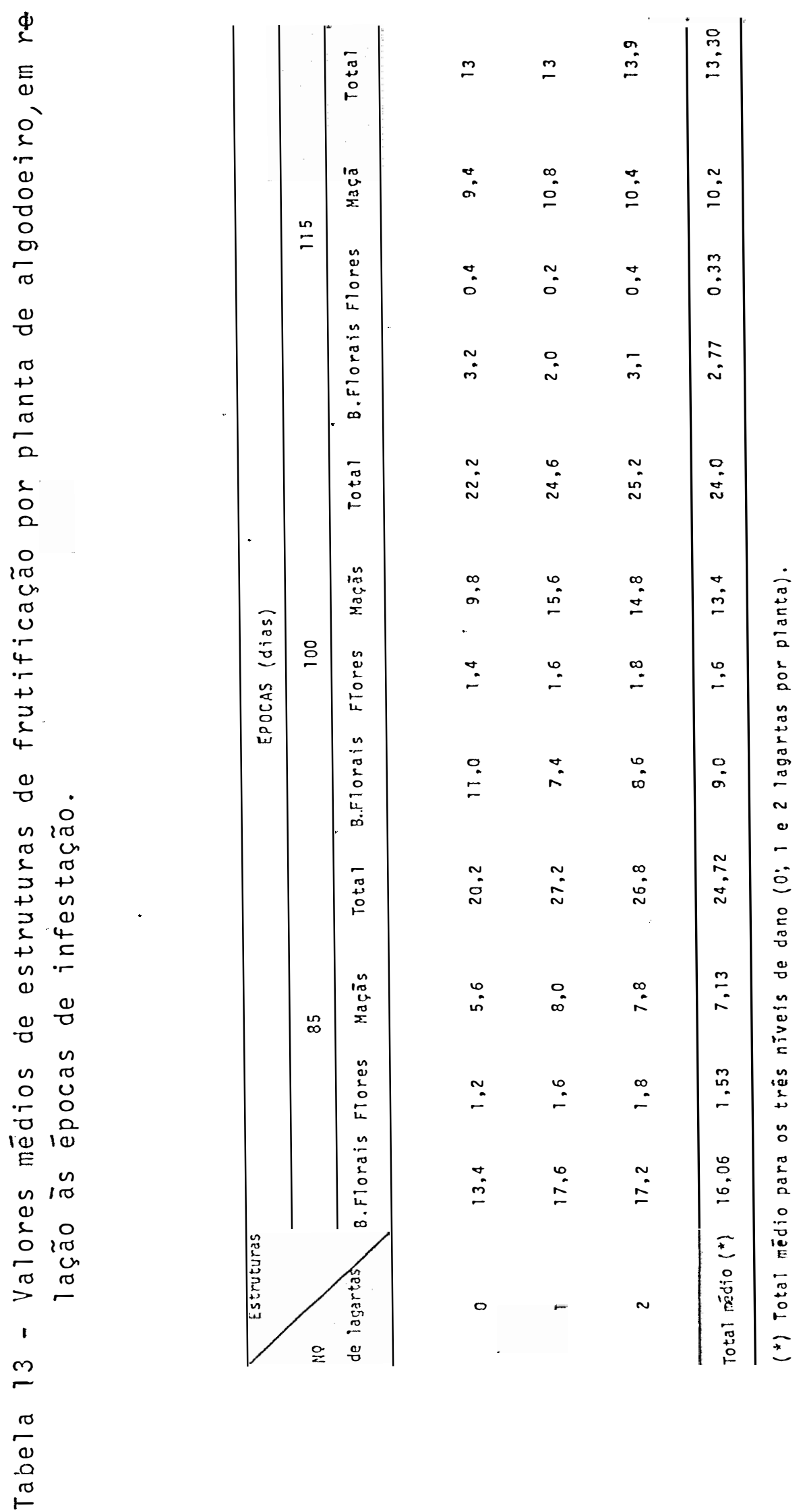


Tabela 14 - Quadrados médios para os nümeros de botões flo rais, maçãs e totais de estruturas danificadas por planta de algodoeiro, pelas lagartas de $S$. Grugiperda em diferentes épocas de desenvolvimen to da cultura (dados transformados em arc sen $\sqrt{\%})$.

\begin{tabular}{|c|c|c|c|c|}
\hline \multirow{2}{*}{ Causas da Variação } & \multirow{2}{*}{ G.L } & \multicolumn{3}{|c|}{ Estruturas frutiferas } \\
\hline & & B.Florais & Maçãs & Total \\
\hline Tratamentos & (5) & - & - & - \\
\hline NO de Insetos (N.I.) & 1 & 48,24 & $371,13 * *$ & $134,40 * *$ \\
\hline Epocas (E) & 2 & 332,85 & 102,35 & 28,79 \\
\hline Interação (N.I.xE.) & 2 & 14,09 & 73,69 & 14,84 \\
\hline Resìduo & 24 & 233,64 & 38,26 & 13,95 \\
\hline Coeficiente de varia & & - & & \\
\hline ção (\%) & - & 56,40 & 21,93 & 14,01 \\
\hline
\end{tabular}

** Significativo ao nível de $1 \%$ de probabilidade. 


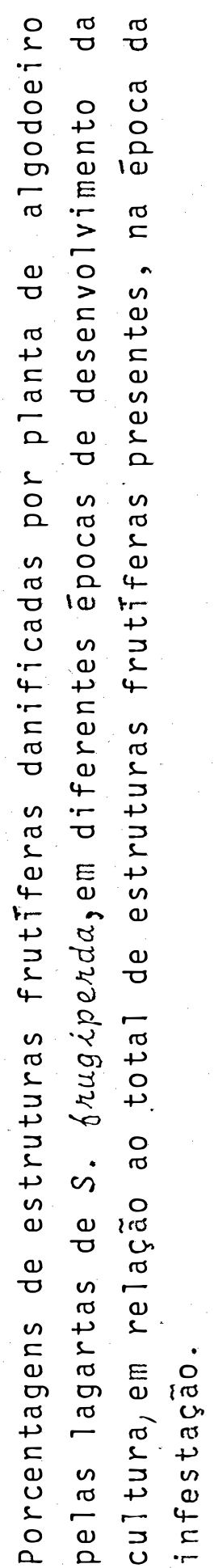

I

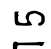

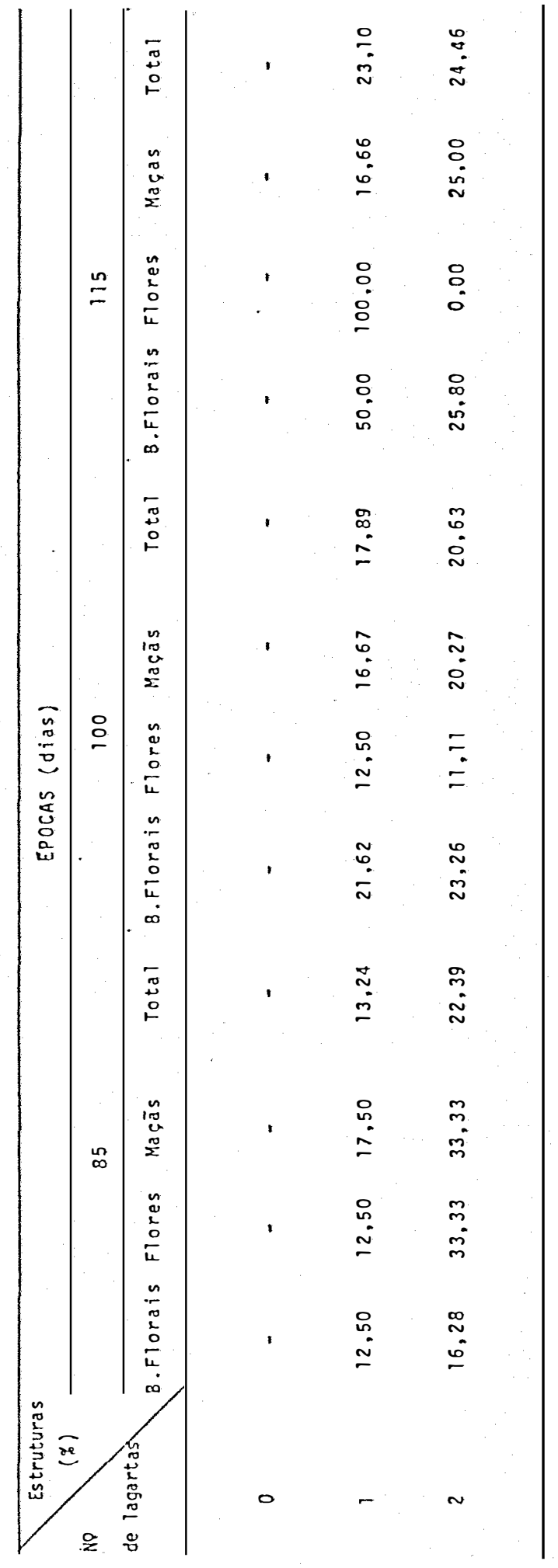

$\sigma$
0
0
0 
78.

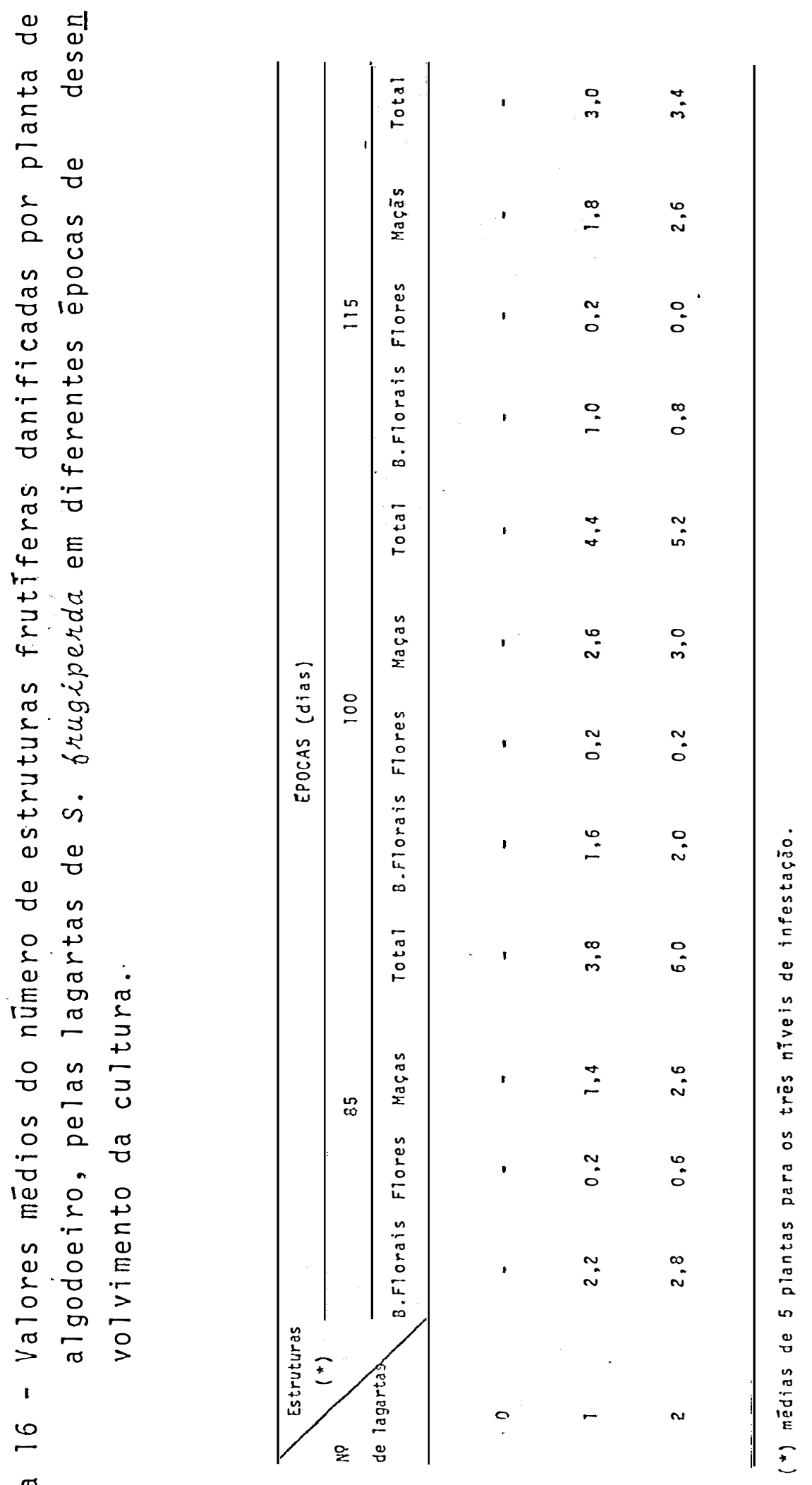

$\sigma$
0
0
0 
79.

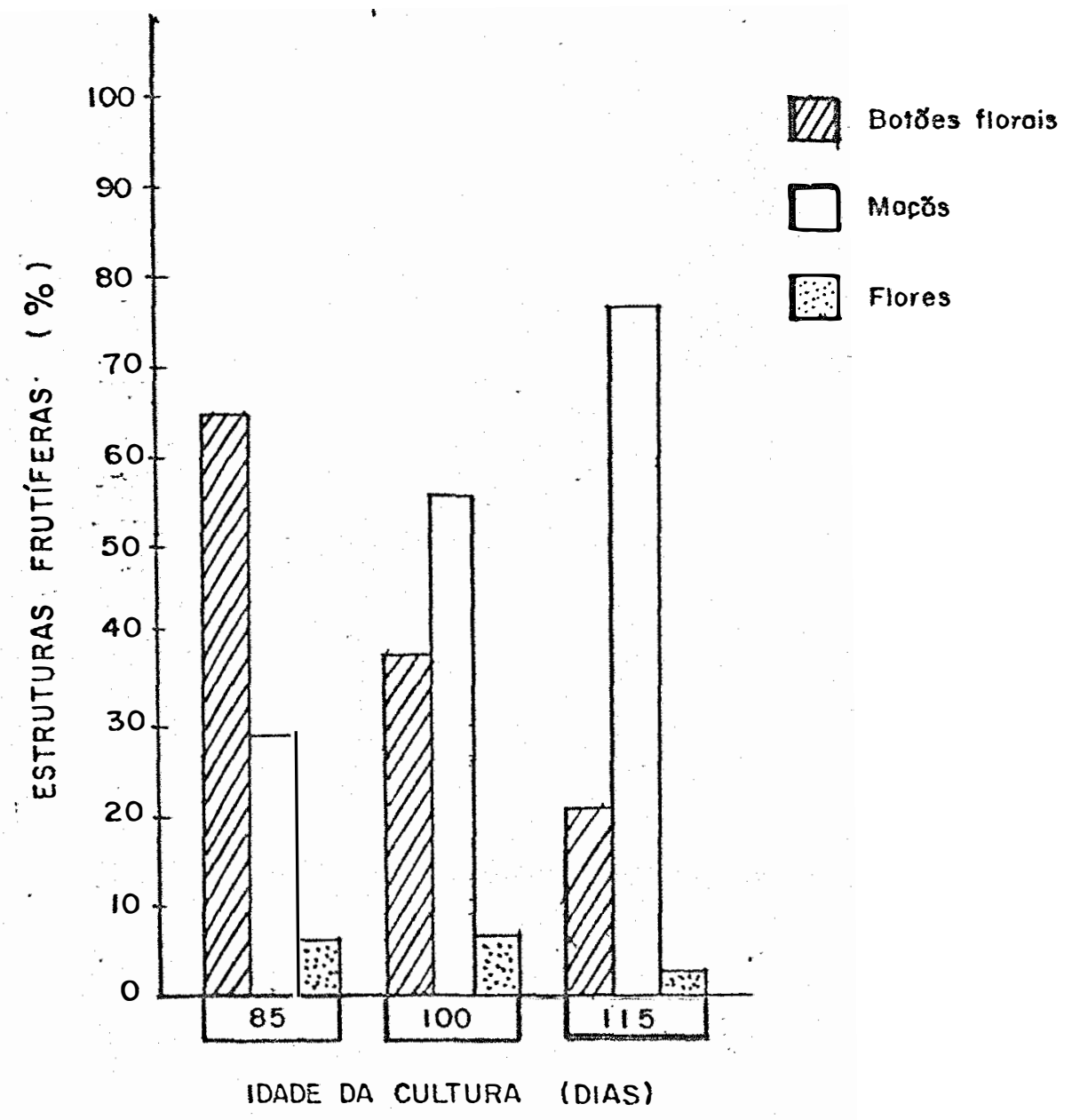

FIGURA 13 - Porcentagens de estruturas frutiferas por planta de algodoeiro em relação às épocas de infesta ̧̧ões 
80 .

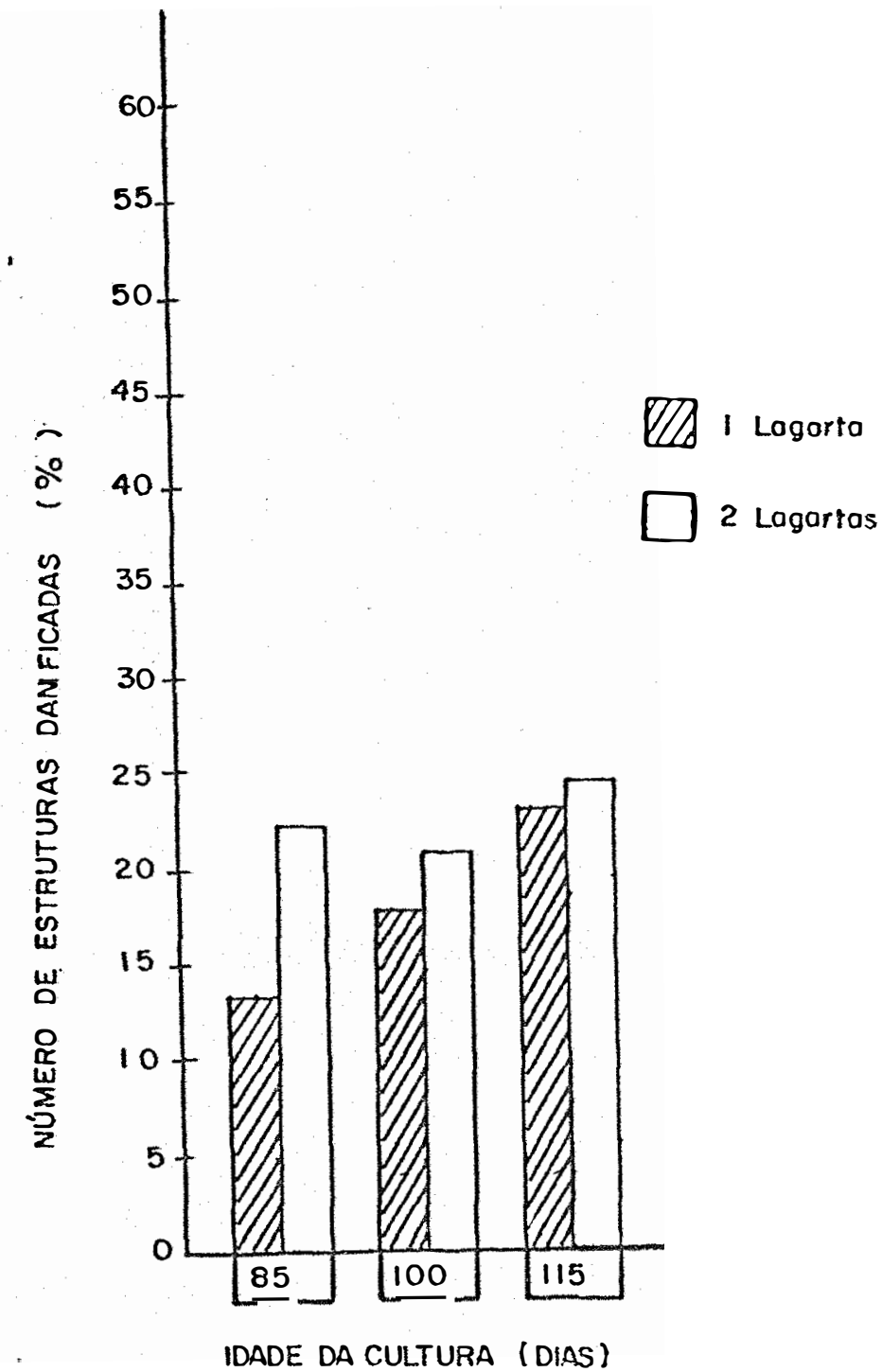

Figura 14 - Porcentagens de estruturas frutiferas danificadas por lagartas de $S$. frugiperda, em relação ao to tal de estruturas frutiferas presente nas plan tas, nas épocas da infestação. 
81.

\section{CONCLUSOES}

Com base nos resultados obtidos no presente trabalho podem ser estabelecidas as seguintes conclusões:

- As lagartas criadas em folhas de milho apresentam perío do larval mais curto, mas, o substrato alimentar não influ encia o peso das lagartas;

- 0 número de instares larvais é 7 em algodoeiro e 6 em mi 1ho;

- Folhas de milho são mais favoráveis para postura e desen volvimento do inseto;

- A viabilidade para todos os parámetros analisados ē sem pre maior para os insetos criados em folhas de milho;

- 0 ciclo total é de 43,36 e 38, 14 dias, respectivamente, pa ra algodoeiro e milho;

- Hã diferença significativa na produção de algodão em caro ço em plantas infestadas com 7,2 e 4 lagartas aos 75 e 95 dias apōs a germinação; 
- Aos 75 dias (na ausência de estruturas frutíferas), a redu ção na produção ocorre devido ao ataque das lagartas aos ponteiros e aos caules com cortes parcial ou total. Aos 95 dias, os ponteiros não são danificados;

- Aos 95 dias a produção diminuiu linearmente em relação aos diferentes niveis de infestação, provavelmente, devido a preferência das lagartas pelas estruturas frutiferas nesta época, entretanto, não ocorreu mais de umalagarta no ūltimo instar por maçã;

- 0 número de pupas, resultantes das plantas infestadas pe las Jagartas, é significativamente maior aos 95 dias da germina ção;

- Uma lagarta de $S$. frugiperda destrōi, durante o seu desen volvimento, 3,78 estruturas frutíferas;

- Não hā diferença significativa com relação às diversas épo cas de infestação, para os danos provocados nas estruturas frutiferas com 1 e 2 lagartas. 


\section{LITERATURA CITADA}

AGROANALYSIS, 1982. Grupo de Informação Agrīcola do Instituto Brasileiro de Economia da Fundação Getūitio Vargas, Agroana. lysis, Rio de Janeiro, 6 (2): 3-9.

ANTHONY, K.R.M. e R. BRAV0, 1970. Cotton production in Colom bia. Cotton Growing Review, London, 47 (2): 81-92.

AZEVED0, J., 1962. Lagarta-da-folha. Lavoura Arrozeira, Por to Alegre, $16(182): 19-20$.

BAILEY, D.L. e H.L. CHADA, 1968. Effects of natural(sorghum) and artificial (wheat-germ) diets on development of the corn earworm, fall armyworm, and southwestern cor borer. Journal of Economic Entomology, Bronsville, 6] (1): 257-260.

BAFIELD, C.S.; E.R. MITCHELL e S.L. POE, 1978. A temperatü re-dependent for fall armyworm development. Annals of the Entomological Society of America, Columbus, 71 (1): 70-74.

BERTELS, A. e M.A.B. ROCHA, 1950. Observações preliminares so bre pragas do milho. Agros, Pelotas, $\underline{3}$ (3): 160-183.

BERTELS, A., 1970. Estudos da influência da umidade sobre a di 
nâmica de populações de lepidopteros, pragas de milho. Pesquisa Agropecuāria Brasileira, Brasīlia, 5 : 67-69.

BERTOLOTI, S.G., 1978. Avaliação de danos da lagarta rosada Pectinophora gossypiella. (Sauders, 1843) (Lepidoptera Gelechiidae) no algodoeiro. Piracicaba, ESALQ/USP, 74 p. (Dissertação de Mestrado).

BIEZANKO, C.M.; A. RUFFINELLI e D. LINK, 1974. Plantas y otras sustancias alimenticias de las orugas de los lepi dōpteros uruguayos. Revista do Centro de Ciências Rurais, Santa Maria, 4 (2): 107-148.

BOWLING, C.C., 1967. Rearing of two lepidopterous pest of rice on a common artificial diet. Annals of the Entomolo gical Society of America, Columbus, 60 (6) : 1215-1216.

BUTT, B.A. e E. CANTU, 1962. Sex determination of lepidopte rous pupae. USDA, Washington, 7 p. (ARS, $33-75)$.

CANDIA, J.D., 1971. Las plagas del algodon en Bolivia. Revis. ta Peruana de Entomologia, Lima, 14 (2) : 395-397.

CARVALHO, M.B. e R.F. CARVALHO, 1939. Primeira contribuição para um catālogo de insetos de Pernambuco. Arquivos. do Instituto de Pesquisas Agronômicas, Recife, 2 : 27-60.

CARVALho, R.P.L., 1970. Danos, flutuação da população, con trole e comportamento de spodoptera frugiperda (J.E. Smith, 1797 ) e susceptibilidade de diferentes genōtipos de milho em condições de campo. Piracicaba, ESALq/USP, 170 p. (Te se de doutoramento).

COBB, P.P. e M.H. BASS, 1975. Beet armyworm: dosagem-mortality 
studies on California and Florida Strains. Journal of Eco nomic Entomology, Meñasha, 68 (6): 813-814.

COSTA LIMA, A. da., 1950. Laphygma frugiperda (Smith e Abbot, 1797) In: Insetos do Brasil: Lepidopteros, Rio de Janei ro, Escola Nacional de Agronomia, t. 6, pt. 2, p. 2 .

COSTILLA, M.A. e H.D. MERCADO, 1968. La oruga variada Laphygma. frugiperda S. \& A. (Noctuidae) y su importancia en los cuI tivos de Tucumān. Boletin de la Estacion Experimental A grícola, Tocumān (107): 1-4.

COVARRUBIAS, G.R. e F.M. PACHECO, 1970. Evaluación de danos en algodonero por remocion manual de las frutificaciones en la Costa de Hermosillo. Agricultura Tëcnica en México, Cha pingo, $2(12): 527-529$.

CRUZ, I. e F.T. TURPIN, 1982. Efeito da Spodoptera frugiper da em diferentes estádios de crescimento da cultura do mi 1ho. Pesquisa Agropecuāria Brasileira, Brasīia, 17 : 355-359.

DEW, B.J.A., 1913. Fal1 armyworm Laphygma frugiperda (S. \& A.) Journal of Economic Entomology, Geneva, 6 : 361-366.

DORESTE,E.S., 1975. Fluctuaciones de la poblaciōn de algunas plagas en Cagua, Estado Aragua, Venezuela, segūn estudios realizados durante diez años con una tampa de 1 uz. Revis ta dela Facultad de Agronomia, Maracay, 8 (4): 5-24.

DUARTE, J.0.; T.A. VARELA; J.E. VILLA VICENCIO; C.A. MIRANDA; M.A. BRUYEROS; J.A. CASTILLO e Y. TIROSH, 1974. Combate In 
tegrado de las plagas del algodon en El Salvador. Departa mento del algodon - CENTA. Santa Tecla, El Salvador, C.A., $74 \mathrm{p}$.

DYAR, H.G., 1890. The number of moths of lepidopterous lar vae. Psyche, Massachussets, $\underline{5}:$ 420-422.

EL - SAADANY, G.E., 1973. Comparison of mortality factors within a generation of the cotton leaf - worm Spodoptera littoralis. (Boisd). Zeitschrift fur Angewandte Entomolo gie, Hamburg, $\underline{74}: 370-372$.

ESCALANTE, G.J.A., 1974. Contribución al conocimiento de la biologia de Heliothis zea y Spodoptera frugiperda, en el Cusco. Revista Peruana de Entomologia, Lima, 17 (1): $121-122$.

ESTRADA, R.F.A., 1960. Lista preliminar de insetos asociados al maíz en Nicaragua. Turrialba, 10 (2) : 68-73.

ETCHEVERRY, M., 1957. Laphygma frugiperda (ABBOT \& SMITH) en Chile (Lepidoptera" - Noctuidae). Revista Chilena de Ento mologia, Santiago do Chile, $\underline{5}$ : 183-192.

FENTON, F.A., 1952. Field crop insects. New York, Macmillan, $405 \mathrm{p}$.

FONSECA, J.P., 1937. Lagartas nocivas aos milharaes, capin zaes, alfafaes e algodoaes. 므이ógico, São Paulo, $\underline{3}$ (2) : $45-50$.

FONSECA, J.P., 1943. Lagartas nocivas às gramíneas. $\underline{0}$ Bio 


\section{lógico, São Paulo, 9 (12)“: 411-414.}

FURR, R.E. e S.L. CALHOUN, 1952. Toxicity of organic insecti cides to the fall armyworm. Journal of Economic Entomolo. gy, Menasha; 45 (5): 892 .

FYE, R.E. e R.L. CARRANZA, 1973. Cotton pest: overwintering of three lepidopterous species in Arizona. Journal of Eco nomic Entomology, Menasha, 66. (3) : 657-559.

HAMBLETON, E.J., 1939. Notas sobre os lepidópteros que ata cam algodoeiros no Brasil. Arquivos do Instituto Biológi. co, São Paulo, 10 : 235-248.

HENDERSON, C.F.; H.G. KINZER e E.G. THOMPSON, 1966. Growth and yield of grain sorghum infested in the whorl with fall armyworm. Journal of Economic Entomology, Menasha, 59 (4) : $1001-1003$.

HERRERA, J.M.A., 1961. Problemas entomológicos en el cultivo de los algodones Tangüis y Pima en el Perú. Medidas de con trol y su organizaciōn. Revista Peruana de Entomologia,Li $\mathrm{ma}, \underline{4}(1): 58-61$.

HOWELL JR., H.N., 1975. Las plagas del algodón en Honduras y su control. Folia Entomologica Mexicana, México, 33 : 2223.

HOWELL JR., H.N., 1978. Notas sobre el complejo de las plą gas del algodón en Honduras, C.A., su ecologia y su con trol. Ceiba, Tegucigalpa, $\underline{22}$ (1): 29-33. 
HUNTER, R.C. e H. BENITEZ, 1964. La efectividad de algunas insecticidas en el control de los gusanos belloteros. Bo letin Técnico del Instituto de Fomento Algodonero, Bogotá, n. 1, $25 \mathrm{p}$.

HYNES, H.B.N., 1942. Lepidopterous pests of maize in Trini dad. Tropical Agriculture, Saint Augustine, 19 (10): $194-202$.

INSTITUTO DE ECONOMIA AGRICOLA, 1981. Prognōstico $81 / 82$.

São Paulo, Secretaria da Agricultura, p. 77-82.

ISA, A.L., 1977. Pesticide management as practiced in Egypt to control cotton insects in the 1976 season. Cairo, Egypt, Ministry of Agriculture, p. 45-49. Apud: Review of applied Entomology, Ser. A., London, 66 (7): 464-465, 1978.

KASTEN JR., P., A.A.C.M. PRECETTI e J.R. P.PARRA, 1978. Da dos biológicos comparativos de spodoptera frugiperda (J. E. Smith, 1797) em duas dietas artificiais e substrato natural. Revista de Agricultura, Piracicaba, $53(1 / 2)$ : $68-78$

KHALIFA, A., H.S. SALAMA; N. AZMY e A. EL - SHARABY, 1974. Teste sensitivity of the cotton leafworm, spodoptera litto. ralis, to chemicals. Journal Insect Physiology, Great Britain, 20. $: 67-76$.

LABRADOR S., J.R., 1967. Estudio de biologia y combate del gusano cogollero del maíz Laphygma frugiperda S. \& A. Ma 
racaibo, Univ. Zulia, Fac. Agronomia, Secc. Entomologia, 83 $p$.

LARA, F.M. e S. SILVEIRA NETO, 1977. Flutuações populacio nais de noctuídeos pragas, na região de Jaboticabal, São Paulo. Científica, Jaboticabal, $\underline{5}$ (3): 262-270.

LEIDERMAN, L. e H.F.G. SAUER, 1953. A lagarta dos milharais Laphygma frugiperda (Abbot \& Smith, 1797). 믐ológico, São Pau10, $19(6): 105-113$

LLANOS, V.V., 1940. Observaciones entomolōgicas sobre el cuI tivo del algodonero en el Deptọ del Atlāntico. Revista de 1 a Facultad Nacional de Agronomia, Medellin, 2 (6) : 593608 .

LOWRY, W.L. e S. L. CALHOUN, 1952. Control of yellow-striped armyworm on cotton with organic insecticides. Journal of Economic Entomology, Menasha, 45 (4): 741 .

LUCCHINI, F., 1977. Biologia da Spodoptera frugiperda (Smith \& Abbot, 1797) (Lepidoptera, Noctuidae). Níveis de prejuí zos e avaliação toxicológica de inseticidas para o seu com bate em milho. Curitiba, 114 p. (Dissertação de Mestrado). LUGINBILL, P., 1928. The fall armyworm. Technical Bulletin. United States Department of Agriculture, Washington, 34 : $1-91$

LUGINBILL, P., 1950. Habits and control of the fall armyworm. Farmer's Bulletin. United States Department of Agricultu. re, Washington, $1990: 1-11$. 
MARQUEZ, S.A.; J. de la F. VILLARREAL; D.E. SCHALLENMUELLER e J.M. VILLARD, 1963/64. Estudios biológicos del gusano cogollero. Informe Anual de Investigaciōn, Monterrey, Mé xico, $\underline{9}: 27-32$.

METCALF, C.L. e W. P. FLINT, 1965. Insectos destructivos e insectos utiles; sus costumbres y su control. 4. ed. Méxi co; Ed. Continentál, p. 531-533.

PARRA, J.R. P.; P. R. REIS e A. H. CAMARG0, 1971. Resistên cia de milho a spodoptera frugiperda (J.E. Smith). II. Efei tos de diferentes temperaturas sobre a conservação de $\underline{p} \underline{u}$ pas. Revista de Agricultura, Piracicaba, 66 (1): 32-40.

PARRA, J.R. P.; A.A.C.M. PRECETTI e P. KASTEN JR., 1977. As pectos biológicos de Spodoptera eridania (Cramer, 1782) (Lepidoptera, Noctuidae) em soja e algodoeiro. Anais da So. ciedade Entomológica do Brasil, Jaboticabal, 6- (2) : 147155 .

PARRA, J.R.P., 1979. Biologia dos Insetos. Escola Superior de Agricultura "Luiz de Queiroz" - ESALQ/USP. Piracicaba, 383 p. (mimiografado).

PATEL, P.N., 1981. Estudos de fatores bióticos de controle natural em populações de Spodoptera frugiperda (J.E. Smith, 1797) (Lepidoptera : Noctuidae). Campinas ESALQ/USP, 98 p. (Dissertação de Mestrado).

PENAGOS, H.D., 1974. Evaluación de cinco insecticidas para el control del gusano cogollero (Spodoptera frugiperda, J. 
E. Smith). Revista Cafetalera, Guatemala (134): 25-30.

PEREIRA, L.H., 1971. A lagarta Spodoptera frugiperda (Smith

e Abbot, 1797) nos algodoais do Paraná. Arquivos de Biolo. gia e Tecnologia, Curitiba, 14 (1): 6-7.

PICCININ, L. e F.M. LARA; 1977. Espécies e respectivas por centagens de ocorréncia de lagartas das maçãs do algodoei ro em Jaboticabal - SP. In: IV Congresso Brasileiro de En tomologia, Goiānia, p. 106. (Resumo).

PYENSON, L., 1938. Problems of applied entomology in Pernam buco, Brasil. Parte II - A survey of some of the pest of Pernambuco. Revista de Entomologia, Petrópolis, $\underline{9}(1 / 2)$ : $16-31$.

RANDOLPH, N.M. e P.M. WAGNER, 1966. Biology and control of the fall armyworm. Progress report. Texas Agricultural. Experiment Station. College Station, n. 2431, 6 p.

REVELO, M.A. e E.S. RAUN, 1964. Rearing the fall armyworm un der greenhouse conditions. Journal of Economic Entomology, Menasha, $57(6): 1000$.

REYNOLDS, H.T., P.L. ADKISSON e R.F. SMITH, 1976. Cotton in sect pest management. In: R.L. METCALF e W. LUCKMANN. In troduction to insect pest management. New York, John Wiley, P. $381-443$.

RUPPEL, R.F.; C.B. CARMONA; A.P. FIGUEROA E N.M. DELGADO, 1956. El control del cogollero, Laphygma frugiperda (Smith) em maiz en Colombia; con anotaciones sobre otras espécies. A 
gricultura Tropical, Bogotá, 12 (8): 499-524.

SALAS, L.A.P., 1954. Insectos prejudiciales en el maiz. Meno ramento del maiz; Primera Reuniōn Centroamericana. Turrial. ba, Costa Rica, $\underline{5}: 305-311$.

SALAS A., J.S., 1974. Evoluación de insecticidas en el con trol de plagas que atacan las bellotas del algodón en el Estado Portuguesa, Venezuela. CIARC0, Medellin, $\underline{4}$ (1/2) : $11-19$.

SANTOS, W.J., 1977. Efeito da simulação de danos da "lagar ta da maçã" Heliothis virescens (Fabr., 1781) (Lepidoptera Noctuidae) na produção do algodoeiro. Piracicaba, ESALQ/ USP, 64 p. (Dissertação de Mestrado).

SANTOS, W.J. e C.J. MARUR, 1980. Determinação de épocas e níveis críticos de destruição de estruturas frutîferas em algodoeiro cultivado no Estado do Paranā. In: I Reunião Nacional do Algodão, Londrina. p. 65.

SIFUENTES A., J.A., 1967. Oviposicion de palomillas de co gollero y daño de las larvas en plantulas de maíz y sor go, en invernadero. Agricultura Técnica en México, Cha pingo, $\underline{2}(7): 311-314$.

SILVEIRA NETO, S.; S. CARVALHO; M.F.S. TARRAGO e D. BARBIN, 1979. Influência da vegetação e de fatores meteorológi cos na flutuação populacional das lagartas do cartucho e da espiga do milho em Santa Maria, R.S. Cientifica, Jabo ticabal, $7(2): 183-190$. 
SMITH, B.R.C., 1921. Observations on the fall armyworm (La phygma frugiperda. (Smith \& Abbot) and some control experi ments. Journal of Economic Entomology, Menasha, 14: 300308 .

SQUIRE, F.A., 1972. Entomological problems in Bolivia. Pest

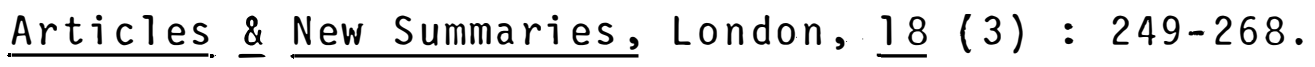

STARKS, K.J. e R.L. BURTON, 1979. Damage to grain sorghum by fall armyworm and corn eaworm. Journal of Economic Entomo. logy, Menash, 72 (4): 576-578.

TAYLOR, J.S., 1931. Notes on the biology Laphygma exempta, Walk., and L. exigua, Hbn. (Lep., Noctuidae). Bulletin of Entomological Research, London, 22: 209-210.

VELEZ, M.C. e J.A. SIFUENTES A., 1967. El gusano cogollero del mays: su combate com insecticidas granulados en el Va 1 e de Apatzingan. Agricultura Técnica en México, Chapingo, $\underline{2}(7): 315-317$.

WATERS, H., 1937. Methods and equipment for laboratory stú dies of insecticides. Journal of Economic Entomology, Me nasha, $30: 179-203$.

WENE, G.P. e L.W. SHEETS, 1961. Control of the beet armyworm on cotton in Arizona. Journal of Economic Entomology, Me nash, 54 (1): 192-193: 
94.

7 - APENDICE 
APENDICE 1 - Precipitação pluviométrica e temperatura do ar, mensais, referentes ao ano de 1980 , registradas no Posto Agrometeorolōgico, do Departamento de Física e Meteorologia da ESALQ/USP, em Piracica ba-SP.

\begin{tabular}{lcccccc}
\hline & Precipita- & \multicolumn{5}{c}{ Temperatura do Ar (ọc) } \\
MESES/1981 & $\begin{array}{c}\text { cão pluvió } \\
\text { métrica(m) }\end{array}$ & $\begin{array}{c}\text { Máxima } \\
\text { média }\end{array}$ & $\begin{array}{c}\text { Mínima } \\
\text { média }\end{array}$ & $\begin{array}{c}\text { Máxima } \\
\text { absoluta }\end{array}$ & $\begin{array}{c}\text { Mínima } \\
\text { absoluta }\end{array}$ & $\begin{array}{c}\text { Amplitude } \\
\text { térmica } \\
\text { média }\end{array}$ \\
\hline Janeiro & 147,6 & 29,7 & 18,1 & 32,8 & 12,2 & 11,6 \\
Fevereiro & 163,3 & 30,7 & 22,9 & 34,8 & 15,2 & 7,8 \\
Março & 42,3 & 32,2 & 18,8 & 34,6 & 16,5 & 13,4 \\
Abril & 186,4 & 28,7 & 16,1 & 31,8 & 13,0 & 12,6 \\
Maio & 13,4 & 27,7 & 12,7 & 30,3 & 7,7 & 15 \\
Junho & 39,3 & 24,9 & 8,1 & 29,3 & 4,1 & 16,8 \\
Julho & - & 26,9 & 9,9 & 31,0 & 7,1 & 17,0 \\
Agosto & 22,6 & 25,3 & 12,1 & 31,0 & 8,5 & 13,2 \\
Setembro & 62,5 & 24,7 & 11,6 & 31,0 & 5,5 & 13,1 \\
Outubro & 52,9 & 28,7 & 16,4 & 35,0 & 10,5 & 12,3 \\
Novembro & 145,2 & 27,4 & 15,9 & 32,0 & 11,0 & 11,5 \\
Dezembro & 185,1 & 28,2 & 18,4 & 31,1 & 16,5 & 9,8 \\
& & & & & & \\
\hline
\end{tabular}


APÉNDICE 2 - Precipitação pluviométrica e temperatura do ar, mensais, referentes ao ano de 1981 , registradas no Posto Agrometeorológico, do Departamento de Física e Meteorologia da ESALQ/USP, em Piracica ba-SP .

Precipita

MESES/1981 métrica(mm).

Temperatura do $\operatorname{Ar}(O C)$

Māxima Mínima Māxima Mĩnima média média absoluta absoluta térmica média

Janeiro

290,1

29,4

$19,8 \quad 36,6$

16,6

9,6

Fevereiro

71,2

32,3

19,0

35,0

16,8

13,3

Março

65,6

31,0

$18,3 \quad 34,9$

13,9

12,7

Abril

74,5

28,8

14,6

31,8

10,3

14,2

Maio

27,9

$12,6 \quad 30,9$

9,5

15,3

Junho

$$
68,5
$$

23,7

$9,4 \quad 28,6$

2,0

14,3

Julho

1,6

23,5

$8,3 \quad 29,6$

$-7,8$

15,2

Agos to

3,6

27,5

10,7

34,0

6,5

16,8

Setembro

5,9

30,5

13,5

36,0

7,4

17,0

Outubro

231,5

27,0

$15,4 \quad 33,4$

11,1

11,6

Novembro

167,2

30,2

18,3

32,9

13,6

11,9

Dezembro

211,2

29,2

18,4

33,8

14,1

10,6 